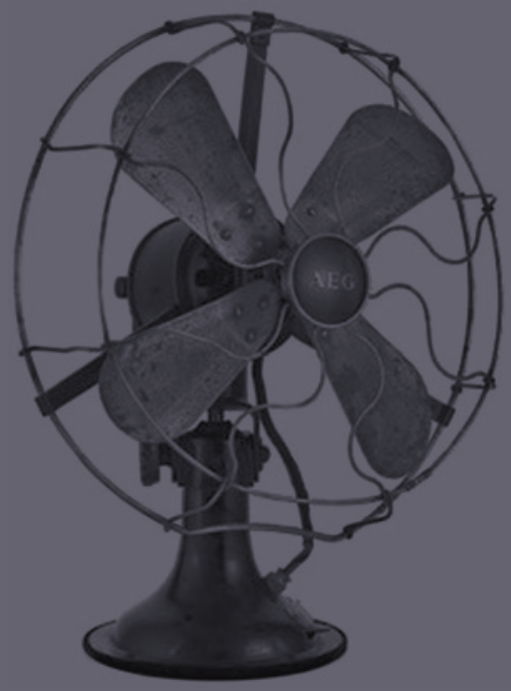

deutcher werkbund 1907



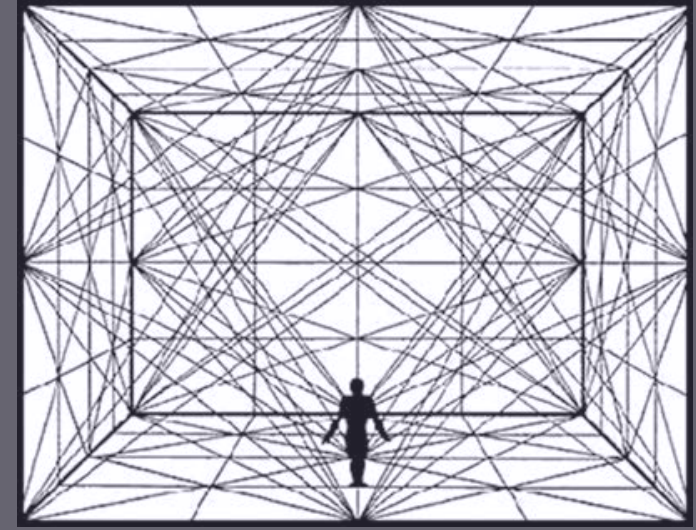

bauhaus 1919-33

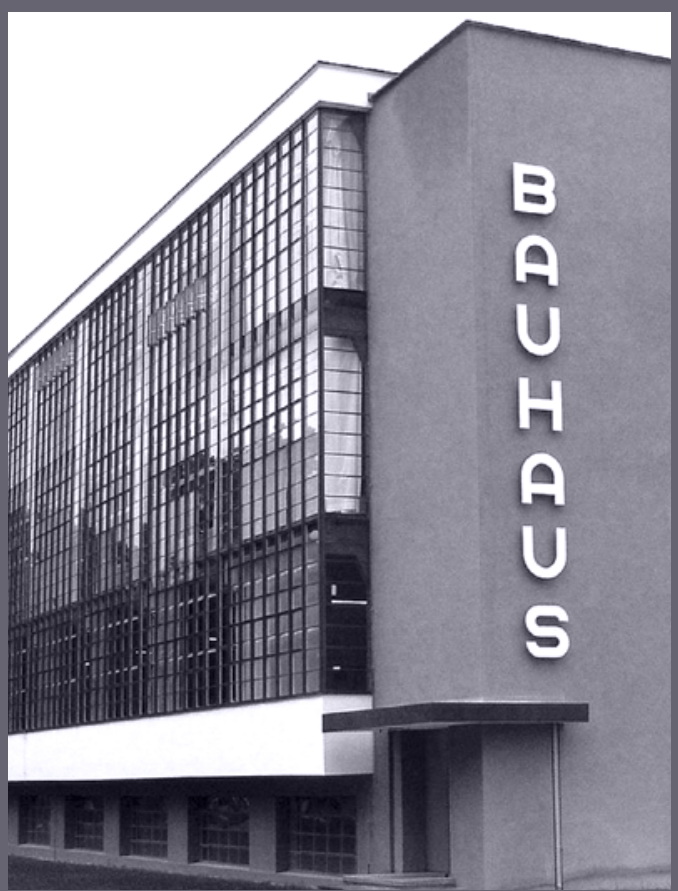




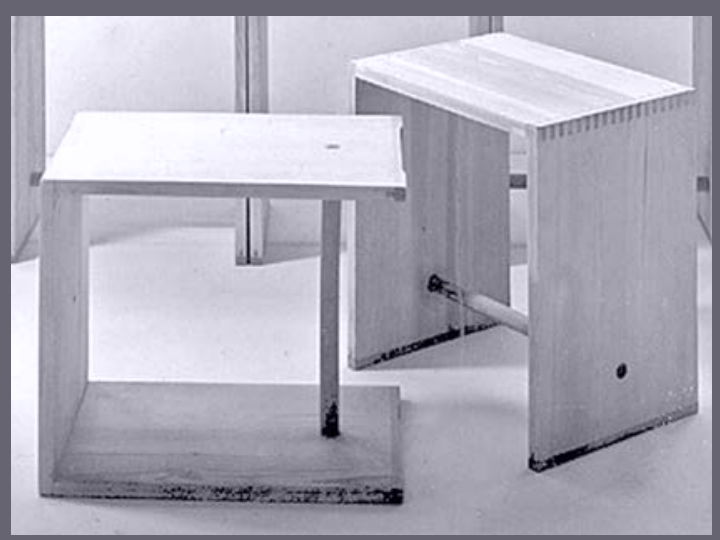

\section{o design moderno}

hfg-ulm 1951-68

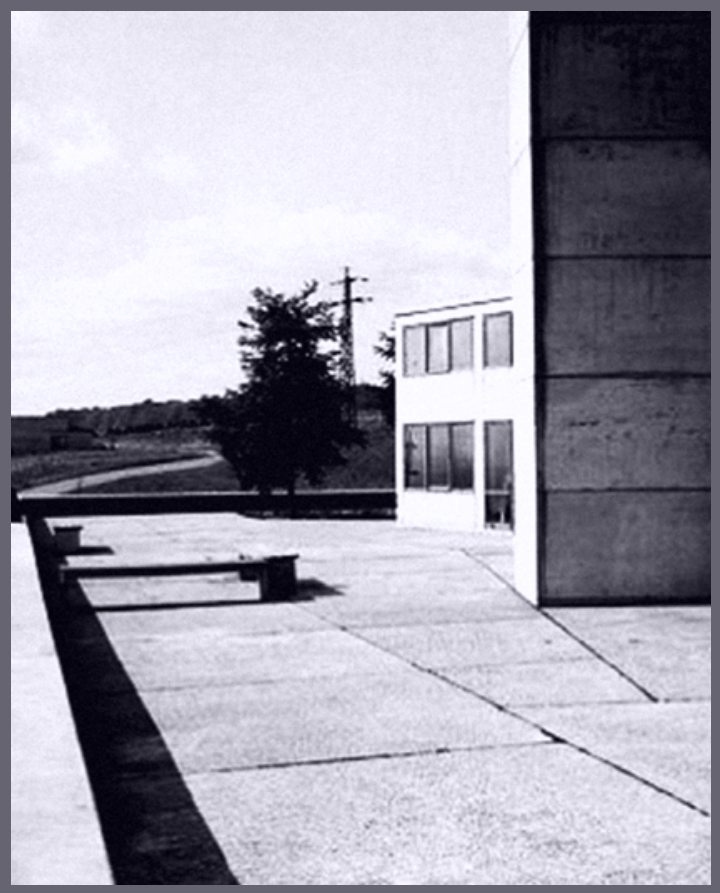



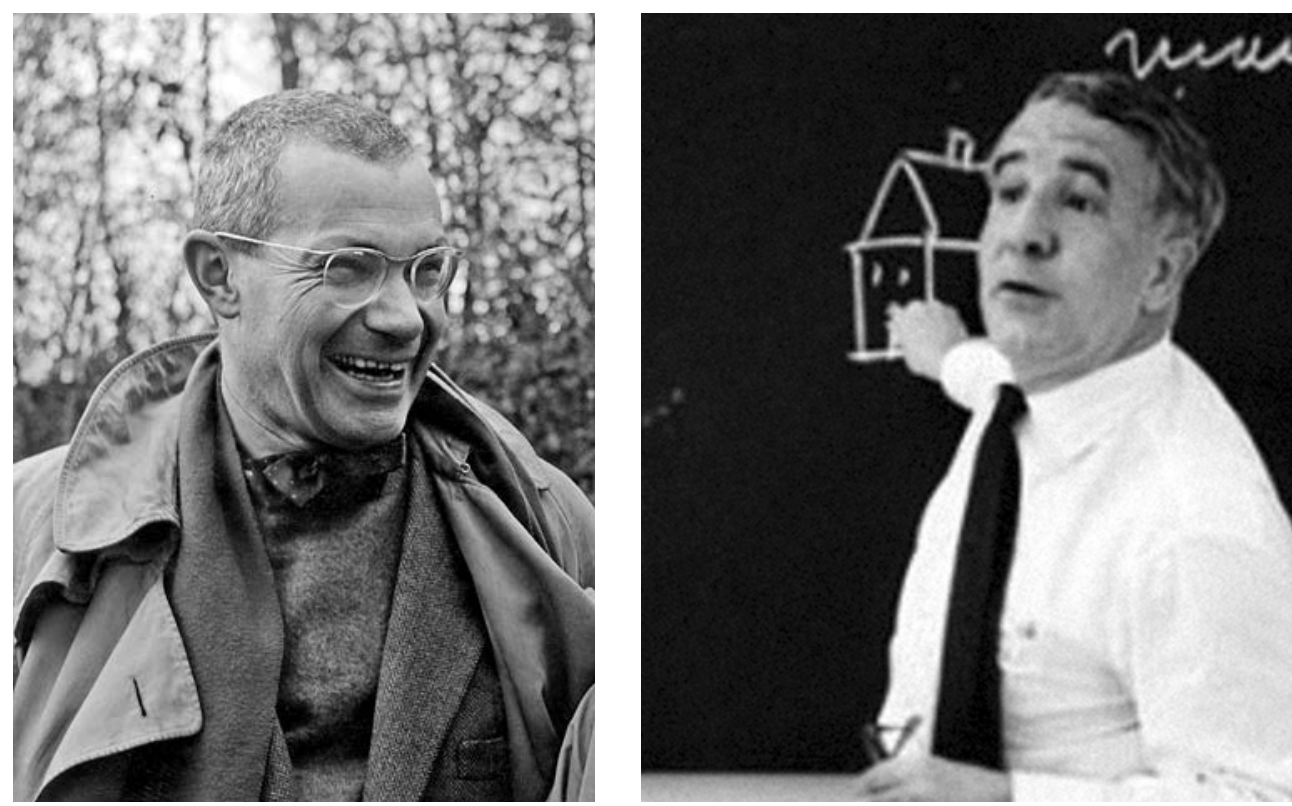

Max Bi11, 1953.

Detalhe foto MU HfG Archiv.

Max Bense, 1964

Detalhe foto Arquivo ESDI. 


\section{o design moderno}

A ideia do design moderno não é uma derivação direta do Grande Racionalismo, ainda que consideremos a presença irrefutável do pensamento cartesiano em sua essência e que o apelo constante ao método seja a sua maior característica. O problema maior parece residir em uma evolução; e toda evolução significa, por um lado, aprimoramento e, por outro, reducionismo de uma ideia básica. Essa evolução tem seu ponto de partida real no Racionalismo Crítico de Karl Popper ${ }^{1}$ e Hans Albert, ${ }^{2}$ concepção filosófica que me parece bastante próxima das ideias do design moderno.

Na curta história do design moderno, a razão não é uma ideia muito precisa até porque, ao contrário do que ela faz supor, não há um único tipo de razão. Em filosofia, ao se falar de razão, procura-se sempre indicar de que gênero, classe, forma, modo ou tipo se trata, e o conjunto é bastante extenso. Há a razão universal, a particular, a natural, a adequada, a humana, a divina, e assim por diante. Agregar um adjetivo ao termo "razão" pressupõe diferentes ideias ou territórios da razão. A razão pode ser entendida em alguns casos como uma faculdade; em outros, como um conceito; pode-se ainda equiparar a razão ao intelecto ou pensá-la como o equivalente a uma prova ou uma explicação. A ideia de razão presente no ideário do design moderno é uma composição livre de características de diversos tipos. Poderíamos, usando um bom manual de filosofia, adotar uma classificação genérica dos tipos de razão que interferem nessa composição, a qual se apresentaria da seguinte maneira: razão analítica, razão concreta, razão crítica, razão dialética, razão histórica, razão instrumental, razão mecânica, razão prática e, por decorrência, a razão teórica.

Da razão analítica decorrem as características de distinção, classificação, dedução e decomposição de um todo ou de um conjunto, em suas diversas partes e outras operações semelhantes. A razão analítica utiliza modelos constituídos por objetos abstratos, apresentando, portanto, estreitas referências com outro tipo de razão, a abstrata, de tal modo que, muitas vezes, essas expressões são usadas como equivalentes. Em muitos casos, esses tipos de razão baseiam-se em procedimentos lógicos e matemáticos de inferência e dedução. No caso do design, percebe-se uma presença importante das características de distinção e classificação em seus procedimentos metodológicos e sistemáticos e, por outro lado, uma grande insipiência nas últimas qualificações referentes à lógica e à matemática. Apenas em alguns casos específicos e, curiosamente, sem maior aprofundamento prático, podem-se encontrar alguns resultados interessantes do que se poderia interpretar como um design dedutivo, entre eles os estudos desenvolvidos por Christopher Alexander, em Notes on the Synthesis of Form, ${ }^{3}$ e John Christopher Jones em Design Methods. ${ }^{4}$ Verificou-se, em setores ligados à pedagogia e à pesquisa em design, uma tentativa de dar à atividade um caráter mais preciso, em que o conceito de razão analítica desempenhou papel importante. Porém, tais esforços geraram mais exemplificações e elaborações quantitativas que resultados práticos reais. Não se pode, no entanto, desconsiderar a ascendência desse trabalho na constituição de uma retórica própria e típica de um design que tentou - baseado em procedimentos metodológicos e na análise crítica dos métodos — não só uma aproximação técnica e precisa com os setores produtivos como também com instituições responsáveis por trabalhos e serviços que demandassem princípios de ordenamento e planejamento social.

Outra característica do design moderno é o uso de procedimentos descritivos, a ponto de criar um termo bastante ambíguo para qualificar este trabalho: situar um projeto. Seria mais correto falar em definir ou descrever o conceito de um projeto ou de um produto. A razão concreta estabelece-se sempre mediante descrições. Constitui-se na base do que se chamou de razão narrativa ou razão histórica, ambas podendo ser vistas como subtipos da razão concreta, ainda que, em termos 
gerais, esta seja uma noção menos precisa que as outras duas. A razão dialética pode ser chamada de razão concreta, com o objetivo de diferenciar-se da razão abstrata, mas apresenta outras características que a tornam singular. A expressão "razão concreta" não é tão nova como se pensa, ela já era usada por alguns escolásticos. Mas seu uso tornou-se generalizado a partir das interpretações elaboradas por Hegel. A razão concreta, baseada em extensas descrições, pode ser considerada fundamental no design moderno e uma de suas bases metodológicas práticas. Posteriormente, imaginou-se no design, como em outras atividades criativas e formais, uma superação das interpretações hegelianas, retirando-lhes quaisquer atributos de natureza subjetiva, incluindo-se as questões estéticas filosóficas e interpretativas, priorizando-se uma estética da constatação. Como disse Max Bense, ${ }^{5}$ que exerceu influência na HfG-Ulm, e em etapas preliminares da ESDI, o método de trabalho da estética moderna é a constatação: ela nos dá certos atributos (numericamente acessiveis) da realidade estética, que só a caracterizam de maneira detalhada e abstrata, porém objetiva e material.

[...] Naturalmente esta estética não pode ser qualificada como estética filosófica. As reflexóes metafísicas lhe são essencialmente estranhas. Prevalecem nela, ao contrário, pontos de vista matemáticos e tecnológicos. Dai ter-se falado não só de uma estética matemática, mas também de uma estética tecnológica. Não se trata de uma estética do gosto, mas de uma estética da constatação, na qual estados estéticos, seus repertórios e seus portadores são descritos de forma objetiva, material e exata, na linguagem abstrata de uma teoria geral empirica e racional. Sob este aspecto, a denominação estética abstrata, também seria adequada. ${ }^{6}$

É interessante nesse particular lembrar o que disse Konrad Fiedler," no ensaio "Del Giudizio sulle opere d'arte figurative" publicado no livro La Critica d'arte moderna, de Roberto Salvini (Firenze: L'Arco, 1949). “O juízo estético sobre a presença da beleza ou não em um objeto, sobre seu bom ou mau gosto, não está submetido, segundo Kant, a nenhuma lei de validade geral: é puramente subjetivo e, em cada caso particular, o gosto deve escolher seu próprio juízo; completamente diverso é o juízo artístico, que pode e deve referir-se, em cada passo, a determinados cânones de validade geral, porque este não se expressa através do gosto, mas do intelecto".
Chamou-se de razão crítica àquela utilizada por Kant para examinar criticamente a razão pura. A razão crítica é uma razão que se autoexamina, critica a si mesma, ou seja, critica os próprios pressupostos. O criticismo foi uma atitude filosófica correspondente aos princípios da razão crítica. O racionalismo crítico, de Karl Popper e Hans Albert, também pode ser interpretado como um tipo de razão crítica, assim como o conjunto das ideias dos pensadores ocupados com a elaboração de uma teoria crítica. No caso específico do design, verifica-se que esse tipo de razão predominou em aspectos discursivos, sendo mesmo confundido com uma teoria do design, o que não parece de todo correto, pois o criticismo em design, aparentemente, dirigiu-se mais a uma crítica da prática de projeto e de seus objetivos que à elaboração de uma teoria. Pode, portanto, ser considerado contribuição importante à elaboração de uma teoria, não se constituindo em teoria em si. A preocupação com uma teoria é típica do design moderno, ou seja, não há um interesse significativo e visível em sua elaboração em períodos anteriores à sua interação com a ideologia industrialista. A construção de uma teoria demandaria uma aproximação maior da razão crítica com ideias contidas no conceito de uma razão concreta. Demandaria ainda, como consequência, maior precisão terminológica o que, apesar de muitos esforços desenvolvidos, não resultou num trabalho real e objetivo. A questão de uma teoria do design permaneceu, ao longo de sua história, restrita a procedimentos descritivos, bastante problemáticos para esse objetivo, numa atividade que apresenta, necessariamente, um grande número de interações operativas e conceituais com outras de naturezas também bastante amplas.

Deve-se ainda questionar se uma teoria do design deveria ser constituída com base em procedimentos que poderiam ser interpretados como ortodoxos, isto é, que se configurassem como parâmetros antes adequados a atividades de características diferentes. A respeito da razão crítica deve-se lembrar de que Karl Popper não considerava válida a proibição de questões práticas e éticas. Tanto Popper como Albert manifestaramse claramente interessados em uma sociedade aberta, melhor, mais esclarecida e emancipada. Sua opção pelo racionalismo crítico, contrária a qualquer forma de irracionalismo e contra toda corrente científica e social que 
se oponha ao progresso, constitui-se em uma decisão prática e ética, apoiada numa fé na capacidade da razão humana, que não necessita abrir mão das tradições do Iluminismo. O pensamento esclarecedor crítico necessitaria constantemente da transposição de um modelo da racionalidade apoiada no método do ensaio e do erro, para as questões da sociedade, da política e do sujeito individual. Seria um modelo apoiado necessariamente na ideia de provisoriedade de todo enunciado científico. Pretenderia ser válido para todas as ciências e fornecer critérios de decisão para a sociedade e para as ações políticas e individuais e, sendo assim, os conflitos humanos, sociais e políticos passariam a ser interpretados como questões científicas em aberto a serem resolvidas com o auxílio de discussões racionais e por meio de decisões democráticas. Karl Popper reconhecia que, para se chegar ao ideal da pesquisa pura da verdade e à realização de uma sociedade humana esclarecida racionalmente, aberta e liberal, não bastariam os conhecimentos estruturados por meio das ciências, necessariamente em estado provisório e falível. Seria necessária uma força de imaginação criadora do sujeito agente, uma "audácia do pensamento", e apenas essa "força de imaginação criadora" seria capaz de esclarecer o homem sobre problemas novos. Jürgen Habermas ${ }^{8}$ faz restrições ao sentido de "esclarecimento" de Karl Popper quando afirma sua limitação ao se resignar a justificar o racionalismo crítico, sua própria decisão pelo esclarecimento, apenas à custa de uma profissão de fé. Creio que nesse ponto reside uma diferença bastante sensível entre a primeira geração de professores da ESDI e a segunda geração, ainda que esta seja, antes da realização dos concursos públicos, fundamentalmente constituída de alunos escolhidos pelos mestres fundadores. - Os primeiros são homens de fé e os segundos homens da dúvida.

Na prática de Bergmiller, encontram-se elementos predominantes do racionalismo crítico de Karl Popper e Hans Albert: a ideia de examinar um problema em todos os seus detalhes, estabelecer um conceito em relação a ele e, mais tarde, por intermédio desse conceito desenvolvê-lo criticamente. Mas, não se deve ser radical nessa interpretação. Max Bense sempre se manteve próximo a Max Bill. No entanto, não se pode de forma tão livre enquadrá-los no mesmo ideário. Um era teórico e crítico; o outro crítico, sim, porém artista e como tal, menos preocupado com uma retórica mais circunscrita. No entanto, pode-se verificar na própria prática de Max Bill uma grande aproximação com o que Bense preconizava. Em Bergmiller, aluno e colaborador de Max Bill, pode-se acrescentar a crença no esclarecimento, característica do racionalismo crítico de Albert e Popper, assim como sua abertura para a mudança.

A Escola de Frankfurt ${ }^{9}$ acrescentou um sentido mais humanista nesse cadinho mental, como diria o saudoso, e diferente de nós, Aloísio Magalhães. ${ }^{10}$ Essa influência pode ser identificada, em Ulm, por intermédio do trabalho de Tomás Maldonado. E podemos ver em Jürgen Habermas uma relação estreita com o pensamento de Frankfurt e aceitar sua observação referente a uma questão de fé. Mas, afinal, não estamos escrevendo um livro para a elaboração de uma defesa contra coisa alguma. As questões no design, assim como em todas as outras áreas da atividade humana, não são um julgamento, não se encontram em um tribunal no qual se deva, necessariamente, concluir com um veredito. Mas foi, sem dúvida, o entendimento - típico de Bergmiller - de que tudo tem de ser visto como algo a ser constantemente mudado e aperfeiçoado, de que uma atitude experimental é a essência de um design progressivo, sua maior contribuição para uma crítica do design. Resta, todavia, uma diferença significativa a ser esclarecida ao final desta consideração: Bergmiller acredita nisso como um projeto, posiciona-se, portanto, como um idealista; quanto a mim, eu vejo nisso um processo e, logo, diante dos fatos e das circunstâncias atuais, principalmente diante da diferença entre o anarquista do século XIX e os homens-bomba da infeliz Palestina contemporânea, vejo-me na irremediável trincheira do pessimismo.

Mas, afinal, alguém poderá perguntar o que essas considerações todas têm a ver com o design? Para uma pergunta dessas sempre haverá respostas medíocres. Não as daremos. É importante afirmar apenas que o design pode ter sido a nossa vida ou, pelo menos, uma parte importante de nossa vida. E se o tivéssemos tratado como algo à parte dessas vidas, em nossas próprias convicções, não teríamos desenvolvido uma atitude crítica, portanto, honesta.

Somos professores, e a principal condição necessária para isso é uma honestidade que nos permita dizer que também erramos, principalmente ao nos dispormos a experimentar. Muitos professores no Brasil fizeram mais do que dar aulas. Podemos nos lembrar de um deles, 
em especial, Mário de Andrade, ${ }^{11}$ que depois de algum tempo confessava o desapontamento com sua tarefa, o que pode nos ajudar a pensar sobre um design imaginado, seu ensino e seu resultado real. Mário de Andrade, sabemos, desfrutou da amizade e da admiração das boas famílias de São Paulo, da elite burguesa, antiga aristocracia agrária, que se transformou também em burguesia industrial aliada às novas forças imigrantes.

Não sendo um aristocrata de origem, Mário de Andrade proferiu, em 1942, no Rio de Janeiro, a palestra "O Movimento Modernista", em que fala sobre seu desgosto do passado e sobre sua geração:

Se de alguma coisa pode valer o meu desgosto, a insatisfação que eu me causo, que os outros não sentem assim na beira do caminho, espiando a multidão passar. Façam ou se recusem a fazer arte, ciência, oficios. Mas não fiquem apenas nisto, espióes da vida, camuflados em técnicos da vida, espiando a multidão passar. Marchem com as multidóes.

[...] Não tenho a minima reserva em afirmar que toda a minha obra representa uma dedicação feliz a problemas do meu tempo e minha terra. Ajudei coisas, maquinei coisas, fiz coisas, muita coisa! E, no entanto me sobra agora a sentença de que fiz muito pouco porque todos os meus feitos derivam de uma ilusáo vasta. E eu que sempre me pensei, me senti mesmo sadiamente banhado de amor humano, chego no declinio da vida à convicção de que faltou humanidade em mim. Meu aristocratismo me puniu. Minhas intençóes me enganaram. Vitima do meu individualismo, procuro em vão nas minhas obras, e também nas de muitos companheiros, uma paixão mais temporânea, uma dor mais viril da vida. Não tem. Tem mas é uma antiquada ausência de realidade em muitos de nós. Estou repisando o que já disse a um moço [...] E outra coisa senáo o respeito que tenho pelo destino dos mais novos se fazendo, não me levaria a esta confissäo bastante cruel, de perceber em quase toda a minha obra a insuficiência do abstencionismo. Conclui finalmente: $A$ única observação que pode trazer alguma complacência para o que eu fui, é que estava enganado. Julgava sinceramente cuidar mais da vida que de mim. Deformei, ninguém náo imagina quanto, a minha obra - o que não quer dizer que se não fizesse isso, ela fosse melhor [...] Abandonei, traição consciente, a ficção, em favor de um homem de estudo que fundamentalmente não sou. Mas é que eu decidira impregnar tudo quanto fazia de um valor utilitário, de um valor prático de vida, que fosse alguma coisa mais terrestre que ficção, prazer estético, a beleza divina. Mas eis que chego a este paradoxo irrespirável: tendo deformado toda a minha obra por um anti-individualismo dirigido e voluntarioso, toda a minha obra não é mais que um hiperindividualismo implacável! E é melancólico chegar assim ao crepúsculo, sem contar com a solidariedade de si mesmo. Eu não posso estar satisfeito de mim. O meu passado não é mais meu companheiro. Eu desconfio de meu passado. ${ }^{12}$

Imagino que todo professor um dia sente, sentiu ou sentirá o mesmo. Faz parte da sua vida. Mas, ensinar não significa, por vezes, abrir mão do que se é realmente? Ou ensinar significa a imposição autoritária de um conhecimento estabelecido e acabado? Como fugir, se possível for, ao dilema de Mário de Andrade? A tentativa, no caso do ensino do design moderno, consistiu em procurar um ensino menos ortodoxo, menos burocrático, baseado em algumas ideias que foram formuladas e aplicadas no final do século XIX e no início do século XX, dirigidas muito mais ao ensino básico que ao superior, buscando assim maior flexibilidade e mais ampla participação do aluno em sua própria formação. Entre esses métodos pedagógicos, ganharam maior evidência os de Maria Montessori ${ }^{13} \mathrm{e}$ as reformas feitas por Kerchensteiner ${ }^{14}$ no ensino alemão, em princípios do século XX.

Essa foi a grande contribuição do design ao ensino em geral, uma atitude ousada para a época. Admitir que o aluno participe de sua formação significa abrir mão de muitos aspectos autoritários da função do professor. Significa entender que apenas a não participação do aluno será motivo para sua reprovação, se assim pode ser chamada. Significa entender que tal tipo de ensino será sempre experimental, que não poderá, em nenhum momento, constituir modelos ou padrões que sirvam para todos, mas poderá definir modelos e padrões que podem ser constantemente analisados e criticados por todos, em conjunto. Não é um modelo fácil e nem sempre foi bem visto pela sociedade mais conservadora e, muito menos, por alunos mais interessados em inserção rápida e indolor no chamado mercado de trabalho.

As escolas que se dispuseram a tal experiência sofreram duros ataques dos setores conservadores, e as críticas na Der Spiegel, revista conservadora alemã, à Escola de Ulm são um excelente exemplo disso. As críticas dirigidas à Bauhaus também não ficaram atrás e nem 
mesmo sua elegia posterior, sua transformação em mito, as anula; ao contrário, até as reforça. E talvez Ulm nem estivesse adotando de forma tão radical um modelo como o descrito. Mas, era uma escola que exigia, sim, maior maturidade do aluno que a ela se candidatava. Escolas com esse caráter demandam professores que pensem no problema apontado por Mário de Andrade, e alunos que pensem também em professores menos formalizados, capazes de errar, sim, e de construir sobre o erro conjunto uma formulação nova. Um ensino experimental não se baseia nas certezas, e sim na experiência; se pensarmos nas experiências científicas, quem poderá dizer ter atingido um resultado adequado sem a ocorrência saudável do erro? Apenas um afortunado que nunca existiu, um fenômeno inumano que, se existisse, deveria ser isolado como um exemplar raro. Essa é a grande dificuldade de estabelecer um ensino realmente experimental. O próprio processo de seleção, tanto de alunos como também de professores, deveria ser, por sua vez, experimental, mutável e variável, sensível. Assim ocorreu em Ulm? Provavelmente, não em toda a sua plenitude. Mas, de qualquer forma, tentou-se. E poucas escolas foram tão polêmicas nessa tentativa.

Poucos trabalhos profissionais na área do design evidenciaram influência tão acentuada de uma escola como o de Karl Heinz Bergmiller. A HfG-Ulm apresentou realmente características muito próprias e especiais. Há alguns anos, o sociólogo italiano Domenico de Masi ${ }^{15}$ trouxe à luz suas ideias a respeito do trabalho desenvolvido durante o século XX pelo que denominou de "grupos criativos". Em sua obra, ele se limita até a década de 1950 e, com isso, não inclui em suas considerações a Escola de Ulm. Mas uma análise da trajetória dessa escola autorizaria, sem muito esforço, a identificar vários aspectos que, segundo Domenico de Masi, permitem sua descrição como um grupo criativo, remanescente ainda do período anterior à Segunda Guerra Mundial. Exatamente pelo fato de ser posterior a esse conflito, a HfG-Ulm apresenta características próprias e, por vezes, mais complexas que suas antecessoras, principalmente por inserir-se em um fenômeno político mundial novo, a Guerra Fria, e por situar-se em seu epicentro, a Alemanha.

Outra característica da HfG-Ulm é pertencer à herança do design moderno, um tipo de design, como se viu, muito claro e preciso em sua própria circunscrição, definido com base em uma premissa ideológica calcada no industrialismo, ou seja, na hipótese de que a maioria dos problemas de desenvolvimento econômico e social poderiam e deveriam ser solucionados ou, pelo menos, equacionados a partir da lógica de uma produção industrial de larga escala e que tais procedimentos, devidamente democratizados, seriam o melhor roteiro para um mundo mais igual e mais bem estruturado. A ideologia industrialista pertence também à primeira metade do século XX e manifesta muitos aspectos exclusivistas.

Mas, a ideologia do design moderno não pode ser interpretada como um conjunto de princípios unitário e fechado. É, ao contrário, resultado de um desenvolvimento extenso e conflituoso, iniciado ainda no fim do século XIX e que tem um de seus períodos mais radicais na etapa final, situada no tempo da HfG-Ulm. Durante a primeira metade do século $\mathrm{XX}$, marcada pelas duas grandes guerras mundiais, o design sempre oscilou entre orientações formalistas, heranças das escolas de belas-artes, e outras, que buscaram uma superação dessas interpretações. Mas, todas essas orientações coincidiram num aspecto: a partir de fatos ocorridos entre 1865 e 1870, como as guerras de unificação da Alemanha e da Itália, na Europa, da Revolução Meiji, no Japão, e da Guerra Civil, nos Estados Unidos, foi irreversível a preponderância da ideologia industrialista sobre as concepções artesanais, mais condizentes com os regimes agrários e semifeudais contra os quais aqueles movimentos políticos se posicionaram. Atrelado à ideia do industrialismo, o design moderno passou a acreditar na industrialização como uma alternativa válida para o desenvolvimento social geral.

Na Alemanha, particularmente, é possível traçarse um desenvolvimento bastante preciso entre o movimento de reforma do Deutscher Werkbund, ${ }^{16}$ iniciado logo após a unificação do país, até a HfG-Ulm e, considerando-se os acidentes de percurso das duas guerras mundiais, pode-se interpretar esse processo como muito bem-sucedido. Em pouco mais de cem anos, a Alemanha transformou-se numa respeitável sociedade industrial e burguesa, e seu design teve nesse processo um papel ativo. Bergmiller, assim como o relativamente pequeno grupo de designers formado pela HfG-Ulm, pertencem a uma elite resultante desse desenvolvimento. $E$ o fenômeno de restrição quantitativa do grupo egresso da Escola é o fator principal que permite uma identificação 
mais imediata com o conceito de grupo criativo, de Domenico de Masi. Entre os fenômenos analisados pelo sociólogo italiano incluem-se dois particularmente importantes na área do design: a Wiener Werkstätte ${ }^{17}$ e a Bauhaus, o que permite dizer que essa atitude, a formação de grupos criativos, encontrou no design um campo bastante adequado para seu desenvolvimento.

Há que se discutir melhor o conceito de grupo criativo mas, em sua essência, pode-se defini-lo como a reunião de pessoas interessadas em um mesmo objetivo, que apresentam pontos de vista básicos comuns e detalhes contraditórios, dispondo-se, porém, à discussão desses detalhes, até mesmo de forma radical. Tais grupos incomodam muitas vezes e, por se disporem a uma ampla discussão de suas divergências, tornam-se objeto de crítica fácil e sem caráter. A disposição para o novo torna-os fenômenos inequivocamente ligados à ideologia moderna e sua disposição para o conflito, sua aversão ao consensualismo, um fenômeno inequivocamente avesso ao pós-moderno. Talvez por isso, nos últimos anos, a ideologia de um design moderno tenha sido objeto de tantas críticas e observações superficiais que definiam seu término, morte ou simples supressão por uma suposta nova ideologia, mais livre e criativa, sem os freios impostos por princípios ou mandamentos rígidos.

Esses supostos conflitos têm origem em análises do design limitadas a aspectos formais ou a aspectos internos referentes a métodos mais ou menos racionais, ou mais ou menos intuitivos. É a velha e desgastada oposição entre razão e intuição, como se ambas não fossem, há tanto tempo, como ensinou Merleau-Ponty, elementos essenciais à existência do homem e de suas ideias. Mas, essa parece também ter sido uma característica do discurso do design moderno: uma relativa ignorância filosófica, uma arrogância do fazer sobre o pensar, uma separação duvidosa entre teoria e prática, entre filosofia e política, como se houvesse uma vida prática que se sobrepõe à vida em geral, como se houvesse os filósofos; e os demais homens, a quem tais preocupações, por se constituírem em maioria, não diriam respeito. Gramsci, também, há muito tempo, já ensinou que as coisas não são bem assim. E nesse aspecto não se pode dizer que as correntes de pensamento divergentes apresentem características definidas e definitivas. Ao contrário, os pecados e as virtudes existem em ambos os lados, o que apenas evidencia que não há uma razão ou uma verdade a ser comprovada à custa de verificações de coerência, mas uma discussão permanente e rica que pode ser constantemente desenvolvida por meio dos atritos e da verificação de suas consistências.

As questões que foram importantes para a HfGUlm permanecem. Charles Jencks, ${ }^{18}$ crítico e historiador inglês, certa vez definiu o design oriundo de Ulm como um design paramétrico. Seus resultados formais, descreveu-os como "próximos da reticência com detalhes muito diretos e friamente ascéticos". Talvez seja a melhor definição do design de Ulm, formulada por alguém que não teve participação direta no processo de criação, desenvolvimento e encerramento da Escola. Ele dizia ainda que seus produtos aproximavam-se de tal forma da neutralidade que ficava difícil diferenciar uns dos outros, independentemente de suas funções "Quando o design paramétrico assumia alguma metáfora visual, estas eram relacionadas com os computadores e com hospitais, com suas conotações de precisão e neutralidade."

Assim como a Bauhaus, a HfG-Ulm não foi uma escola unidirecionada. Diferenciou-se de sua predecessora em um ponto essencial: enquanto a Bauhaus foi uma escola onde conviveram tendências e orientações diversificadas; em Ulm, houve múltiplas faces de uma mesma ideologia: o industrialismo. As divergências, como disse Maldonado, não foram formais, mas pedagógicas. Não se questionou mais a questão arte ou técnica ou coisas semelhantes. Questionou-se, sim, a forma pedagógica de criar um tipo de profissional para um mundo que já se apresentava definitivamente orientado para a indústria. Era o que se imaginava na época. E o questionamento na área pedagógica, quando feito com propriedade, torna-se um questionamento político. Ulm foi mais política do que habitualmente se pensa. Sua própria permanência como assunto de discussão, sua transformação em uma ideia clássica no design, comprovam-no. Na verdade, só permanecem e se transformam em clássicas as ideias que transpõem os limites em que foram geradas, as que afetam o dia a dia das pessoas em outras esferas e criam novos elementos para a discussão da vida. Ideias clássicas são, afinal, filosofia, concepções de vida, independentemente de serem engendradas nos padrões e locais oficiais em que se entende que a filosofia deveria ser gerada.

Ulm foi o epígono do design moderno. Constituiu a mais radical manifestação de uma atividade absolutamente 
inserida no século XX. A escola apresentou nítidos elementos de produtivismo, de industrialismo, de idealismo, de esquerdismo e, por que não, de conservadorismo. Poder-se-ia perguntar onde ficaria o formalismo? Sim, e a resposta é tão clara quanto imprecisa: em toda parte e em nenhuma. Ou seja, Ulm não centralizou seu interesse na forma, mas o formalismo foi a questão por meio da qual a Escola mais foi citada, discutida ou é lembrada. Criou-se então um estilo Ulm? Sim e não. Da mesma forma que, na Bauhaus, não houve a intenção, pois não era a motivação do grupo que a criou gerar um estilo simplesmente. Mas, ele surgiu de fato, e isso foi inevitável. O grande problema é que durante muitos anos a discussão acerca da questão, que não é secundária, afinal, prevaleceu sobre a discussão de outros aspectos igualmente prioritários.

A HfG não permanece como um tema clássico em razão de suas orientações formais. Elas existem, é evidente, e são suficientemente claras e fortes para nos servirem de referência até hoje. Mas o que nos intriga, deixa-nos inquietos mesmo, é saber como ela foi possível, considerando-se, inclusive, as circunstâncias de tempo e situações políticas. Uma explicação razoável seria sua característica pouco acadêmica, sua aversão a uma estrutura curricular mais rígida e mais estruturada. As diversas publicações surgidas sobre a Escola nos últimos tempos permitem dizer que o currículo nunca foi o mesmo de um ano para outro. Além disso, deve-se considerar que, em sua estruturação original, não foi pensada inicialmente como uma escola de design. A necessidade de reconstrução democrática da Alemanha após a Segunda Guerra e a orientação política social reformista da própria família Scholl, ${ }^{19}$ incentivadora da criação da Escola, conduziram para a discussão de seu caráter algumas das mais criativas personalidades do país. Cogitou-se até mesmo de uma escola de política, de cidadania, pode-se dizer. A opção pelo design não pode provavelmente ser creditada apenas à presença de Otl Aicher, ${ }^{20}$ desde o início, e à decisiva participação posterior de Max Bill. Segundo Kenneth Frampton, historiador inglês, Fritz Winter ${ }^{21}$ e Nonnée Schmidt, ${ }^{22}$ ex-alunos da Bauhaus, presentes na discussão da ideia da Escola, teriam sido os primeiros a cogitar sobre uma escola de design. Mas, a ideia de cultura material não foi exatamente formulada por esses designers. Foi estabelecida por meio de uma discussão preliminar bastante complexa com personalidades como Carl Zuckmayer, ${ }^{23}$ Werner Heisenberg, ${ }^{24}$ Konrad Lorenz, ${ }^{25}$ Carl Orff, ${ }^{26}$ Hans Magnus Enzensberger ${ }^{27}$ e Hans Werner Richter ${ }^{28}$ entre outros.

Cogitou-se definitivamente do design talvez pela presença de Max Bill e a influência de Otl Aicher. Não mais um design restrito à ideia de criação formal, mas como atividade de interesse social, o que não era, de todo modo, uma novidade na Alemanha. A reestruturação do Deutscher Werkbund operada por Muthesius ${ }^{29}$ no final do século XIX, suas polêmicas históricas com Van de Velde ${ }^{30}$ e toda a política desenvolvida antes da Primeira Guerra, não colocavam na ordem do dia a discussão apenas das formas do design, mas seus objetivos e seu direcionamento num país que necessitava desenvolver um mercado interno mais consistente, até por não ter condições de enfrentar comercialmente as potências coloniais dominantes então, como a Inglaterra e a França. Desenvolver produtos mais simples e mais baratos não foi uma questão formal, embora se possam estabelecer considerações interessantes sobre uma ética protestante vigente na Alemanha. Há observações formuladas por demógrafos contemporâneos quanto à natureza das burguesias francesa e alemã. Enquanto a primeira teria chegado ao fim de uma revolução para tomar o poder; a segunda o teria feito mediante um processo diferente, até porque a unificação do país, na guerra de 1865, foi chefiada por prussianos, nobres militares, junkers, pertencentes à elite e à nobreza do país. Dessa forma, enquanto a burguesia francesa substituiu a antiga classe dominante; na Alemanha, houve a necessidade de um longo processo de acomodação com uma elite que só deu seus sinais de esgotamento na República de Weimar. ${ }^{31}$ Enquanto, na França, a burguesia adquiria os hábitos da antiga classe; na Alemanha, era necessária a criação de novos hábitos e novas formas de ser e pensar. As obras de Thomas Mann e Marcel Proust são retratos bastante fiéis desses processos. Kultur na Alemanha não tem o mesmo sentido que culture na França. É um movimento de afirmação burguês, lento e gradual, como gostam os luteranos, menos refinado, mais rude, pois, da mesma forma que deveriam ser aceitos produtos simples e menos luxuosos, uma cultura nova deveria também ser acessível à maior parte de uma burguesia que não tomara à força o lugar de uma nobreza, e que, além disso, já tinha valores diferentes da antiga nobreza francesa. 
Todo o movimento do design moderno alemão parte desse impulso cultural renovador, sempre pautado por um processo que tinha essencialmente motivações sociais e políticas. Ulm pode ser interpretada como um grupo criativo, mas também pertence a esse processo de criação de um ideário burguês alemão. Os conflitos que nela surgiram foram consequência das diversas questões que pautaram a reconstrução democrática alemã. Maldonado disse certa vez que a Bauhaus não se limitou a refletir os problemas da República de Weimar, tentou participar deles, tomou partido, estabeleceu posições e ideias. Ulm também o fez em seu tempo e, talvez, essa seja uma característica das boas experiências no ensino do design moderno: não permanecer alheia à vida.

Poucas atividades dependeram tanto de um ensino sistematizado como o design moderno. Se essa atividade era pensada como um elemento de renovação social, era evidente a necessidade de se revogarem as antigas formas de aprendizado, quase medievais, que se circunscreviam às relações entre mestre e aprendiz. Eram necessários programas de ensino que correspondessem a programas políticos e econômicos. Outra vez pode-se então perguntar, ingenuamente, por que essas escolas foram tão contraditórias e conflituosas? Ora, a resposta parece-nos evidente, pois onde mais haverá conflito senão quando se discute a ação planejada, em que é necessária uma atitude, se não coletiva, ao menos integrada? E por que na área de ensino, os conflitos radicais são muito mais frequentes nas instituições menos acadêmicas? Ora, em umas existe a possibilidade de acomodação de diversas personalidades mais e menos fortes; ao passo que em outras não existe nem sequer a possibilidade da presença de personalidades menos fortes.

Mas, é fato constante que, uma vez estabelecido um plano comum, inicia-se um processo de desgaste que tende a transformar um plano renovador em algo mais acessível, mais palatável para todos. Inicia-se uma acomodação. Bergmiller sempre usou uma frase que para muitos parecia polêmica: "Quando as coisas estão bem é a hora certa de mudá-las." Deve-se pensar essa formulação sob algumas perspectivas diferentes. Reflete inicialmente um estado de espírito que deve ser lido às avessas, pois as coisas lá na Alemanha, na época da criação de Ulm, não poderiam estar mais complicadas. A necessidade de mudança era uma imposição vital e a sua progressão, sua constante mutação, significava aumentar cada vez mais a distância em relação a um passado recente tão desastroso quanto ignominioso. A simples presença de algumas das mais fortes personalidades democráticas da Alemanha durante o processo de estruturação preliminar da Escola indica esse direcionamento. Não se pode dizer que essa orientação tenha sido obra da HfG-Ulm, mas pode-se dizer que ela, como uma instituição sem laços mais imediatos com o passado, certamente absorveu esse estado de espírito de forma bastante clara, e que as divergências sobre restauração, continuidade ou revisão da Bauhaus têm ali seu ponto de partida.

Desde o princípio desse posicionamento ocorre também outro aspecto notável: a ruptura prematura com a infância ou com a juventude, gasta em um tempo obscuro que produziu apenas um passado que não valia a pena ser lembrado. É relativamente cômodo desenvolver hoje tal raciocínio, principalmente para quem nada teve a ver com tal passado. É também fácil exigir posicionamentos críticos, sacrifícios pessoais em nome da clareza histórica, revelação de verdades pessoais que servem para a comprovação de outras tantas verdades, também pessoais. Ora, voltemos a Antonio Gramsci, e aceitemos a ideia de que todos têm uma concepção de vida e, portanto, em certa medida, todos somos filósofos. Mas nem todos somos filósofos profissionais. $\mathrm{Na}$ filosofia, se não podemos ter a certeza, temos pelo menos a convicção de que cada passo torna outros possíveis; enquanto na política, no uso da vida, temos a certeza de que simplesmente realizamos uma corrida de obstáculos sem fim, ou uma corrida que tem sempre de ser recomeçada. Continuando na lógica de Gramsci, podemos afirmar também que todo homem é um ser político, mas nem todos são políticos profissionais. O sentido da afirmação de Bergmiller encontra-se nessas considerações. Em sua concepção de vida e de design, mudar enquanto as condições são favoráveis, enquanto as coisas estão bem estruturadas, significa antecipar-se ao passado. Como Guimarães Rosa ${ }^{32}$ citaria, em epígrafe, no conto "Tresaventura" (Tutameia terceiras estórias), uma forma de estar "...no não perdido, no além-passado..." (citação atribuida a Mnemônicum).

Finalmente, Ulm talvez signifique tanto para nós, designers, pelo simples fato de ter terminado cedo. A esse respeito ocorre-me um texto de Merleau-Ponty, 
dirigido a seu colega de estudo Jean-Paul Sartre, ${ }^{33}$ referindo-se a outro colega e amigo comum, Paul Nizan, ${ }^{34}$ morto prematuramente, e que se transformou em um mito para o pensamento existencialista francês. Depois de sua morte, os poucos escritos de Nizan passaram a servir para todos sempre se questionarem: o que ele diria? O que faria? E se ele estivesse aqui? E Nizan adquiriu assim uma proporção e um vulto maior que sua própria, brilhante, porém recém-iniciada obra. Como escreveu Merleau-Ponty, quase o exorcizando: "Ao que morre cedo se aplicam as medidas da esperança enquanto ao que se perpetua aplicam-se as medidas da morte. Um jovem fez muito se foi apenas promessa. Um adulto, sempre presente, parece nada haver feito." Uma ideia que morre jovem apresenta ainda algo mais: é uma promessa permanente, e esse é um dos problemas relevantes do design moderno e suas escolas originais: a contradição entre sobreviver e permanecer experimental, como verdade para mais adiante e essa hipótese, pelo menos até agora, parece exigir a autoextinção. Pode-se dizer que a HfG-Ulm exerceu para nós o mesmo papel que Paul Nizan para o existencialismo francês. Perpetuamos o enigma; transformamos sua ausência em uma questão permanente. Alguma coisa que talvez não diga mais nada para as gerações mais novas se fazendo, como diria Mário de Andrade.

Mas, como é que Bergmiller foi para Ulm? É interessante, pois foi ao ler uma notícia, na imprensa, sobre uma exposição de obras do acervo do MASP ${ }^{35}$ na Alemanha, onde se falava no grande artista suíço Max Bill, suas ideias e sua obra, que Bergmiller soube que ele estaria encarregado da direção da futura escola. Na verdade, o reconhecimento internacional do trabalho de Max Bill teve início, em 1951, com sua premiação na 1a Bienal de São Paulo. A partir desse fato, iniciou-se também a inserção do movimento concreto brasileiro em um plano externo.

Bergmiller já ouvira falar de Ulm e de Bill, mas a exposição do MASP despertou ainda mais sua atenção. Ulm não tinha uma prova de admissão formal. Era desejável e importante que o candidato tivesse alguma experiência na área de seu interesse. Mas tudo se resolvia numa entrevista, e o preenchimento de um formulário com questões de cultura geral e informações pessoais do candidato. Bergmiller visitou Ulm; apresentou-se como candidato; preencheu o formulário e foi entrevistado por Walter Zeischegg. ${ }^{36}$ Algum tempo depois foi admitido no curso fundamental pela intervenção de Max Bill, que escreveu uma carta de recomendação.

A estrutura de ensino inicialmente proposta em Ulm previa o trabalho dos alunos em escritórios de professores, uma atividade formal na Escola, integrada à proposta curricular. Antes de trabalhar com Bill, Bergmiller trabalhou com Zeischegg e, junto com seu colega Ernst Moeckl, ${ }^{37}$ desenvolveu um programa de iluminação para a Phillips. Zeischegg era um competente profissional, mas conhecido por seu temperamento perfeccionista radical, quase neurótico.

Um dia, Bergmiller viu no quadro da Escola um aviso que informava que Max Bill estava formando um grupo de trabalho. Ele e Moeckl apresentaram-se e foram admitidos. Para o escritório de Max Bil, eles desenvolveram projetos de mobiliário e outros equipamentos para o Hotel Ambassador de Nova Déli; relógios para a Junghans, uma tradicional fábrica alemã; telefones para a companhia estatal de telecomunicações da Alemanha — um projeto complexo devido às leis e normas rígidas então existentes, além de projetos para uma das maiores fábricas de assentos e cadeiras de trabalho desse país. Quando apresentou seu projeto de formatura em 1958, Max Bill já deixara a Escola. Porém, tinha ainda a prerrogativa de manter seu trabalho de orientação de projetos finais. Bergmiller apresentou uma dissertação com critérios objetivos para a avaliação das superfícies nos produtos industriais e, como trabalho prático, o projeto de uma máquina automática para a venda de cigarros. Da banca examinadora de seus trabalhos, além do próprio Max Bill, seu orientador, fazia parte Wilhelm Wagenfeld, ${ }^{38}$ conhecido chefe do ateliê de metal da Bauhaus e notável designer, especialmente dedicado a produtos realizados em metal, vidro e porcelana.

Mas o Brasil não era uma notícia nem tão longínqua e nem tão nova para Bergmiller. O Brasil ocupava um espaço interessante no noticiário, na medida em que apresentava uma grande receptividade para o ideário de uma arquitetura moderna. Aqui já se construíra uma edificação pública, o Ministério da Educação, ${ }^{39}$ o Parque da Pampulha ${ }^{40}$ e diversas outras obras nos padrões de uma nova arquitetura, muito antes de diversos países europeus. Lia-se que o país estabelecia planos para industrializar-se e, principalmente, que ousava construir toda uma capital, uma cidade integralmente nova, projetada por dois arquitetos brasileiros que, não se pode dizer 
que fossem desconhecidos no exterior, Oscar Niemeyer e Lúcio Costa. A imagem do país era extremamente favorável e otimista.

De fato, o Brasil redemocratizava-se também nessa época. Não depois de uma catástrofe como a Segunda Grande Guerra, mas não fazia muito tempo que o Estado Novo fascista havia encerrado seu ciclo histórico. A tradição democrática também não era comum, nem no Brasil, nem na Alemanha. Em ambos os países era necessário, sobretudo, o aprendizado democrático. Pode-se dizer que o tempo demonstrou as diferenças entre as duas culturas; os resultados foram completamente distintos. Da mesma forma, pode-se dizer que, se na Alemanha não havia uma tradição democrática, havia um projeto de estabelecimento de uma sociedade burguesa e industrialista. No Brasil isso não existia. O melhor exemplo de uma tentativa nesse sentido foram as ideias de Roberto Simonsen, ${ }^{41}$ um empreendedor brasileiro, de origem burguesa, engenheiro e, posteriormente, político atuante, uma personalidade a quem Antonio Gramsci chamaria sem dúvida de "intelectual orgânico". A exemplo de um seu antecessor, o Visconde de Mauá, ${ }^{42}$ outro referencial do industrialismo brasileiro, Roberto Simonsen foi um homem de ação e de palavras. Falou, escreveu, deixou uma obra clássica sobre economia brasileira, fez discursos, expôsse e levantou questões básicas como o despreparo do país para um projeto real de renovação e de reforma estrutural. Apontou a necessidade de reformas profundas na educação e no preparo de pessoal apto a essas renovações e reformas. Finalmente levantou uma questão fundamental: considerava o país despreparado para esses passos pelo simples fato de não existirem dados confiáveis sobre sua própria situação econômica e social. Achava ele - que era fundamentalmente um político conservador, com uma lógica meridiana que faltava aos políticos progressistas de então - que sem dados sociais e econômicos confiáveis não haveria possibilidade de se estabelecer no país uma cultura de planejamento. Pode-se simplificar essa sua interpretação dizendo, também, que faltava ao país um nível de política que permitisse a assimilação da noção de projeto. $\mathrm{E}$ isso teria consequências graves nas tentativas posteriores de implantação de qualquer iniciativa na área da produção industrial.

Simonsen não via na universidade brasileira potencialidade imediata para desenvolver os trabalhos básicos.
Considerava-a, já na época, lenta e excessivamente apegada a certos mandamentos acadêmicos que dificultavam a apreensão de uma ideologia funcionalista mais pragmática, como ele imaginava. Criou então, junto com outras personalidades de destaque na burguesia brasileira, mais precisamente de São Paulo, a Escola Livre de Sociologia. ${ }^{43} \mathrm{O}$ programa original dessa escola era bastante claro a esse respeito. Funcionando em estreita colaboração com a Faculdade de Ciências Sociais da USP, essa instituição apresentava maior facilidade operacional, flexibilidade curricular e, principalmente, podia desenvolver sem maiores complicações burocráticas pesquisas e estudos encomendados pela iniciativa privada. Mais tarde, essa escola transformou-se em Escola de Sociologia e Política e deu origem a um número significativo de sociólogos brasileiros que viriam a desempenhar importantes papéis na vida acadêmica e política nacional. À sua função de pesquisar e definir dados confiáveis foi agregada também a de formar quadros devidamente preparados para lidar com as questões de planejamento. Essa preocupação de Simonsen, e de outros, demonstra uma coisa muito clara: as ideias de planejamento e de projeto, ou seja, a ideia de longo prazo no Brasil, não era algo muito agradável para o tipo de política aqui praticado. Até mesmo na ditadura do Estado Novo, que durou mais de quinze anos, os elementos de planejamento econômico são marginais ao exercício do poder. Uma elite que se perpetuava no poder, extremamente competente para jamais ser ameaçada em sua hegemonia, sempre soube cuidar para que pouca coisa se alterasse na forma de organização do trabalho e na distribuição de propriedade e renda. A ideia de planejamento era desnecessária para tal elite e, eventualmente, poderia até constituir-se em ameaça à sua hegemonia. E assim Roberto Simonsen transformou-se em tudo: em homenageado e em homenagem, prêmio, nome de ruas, praças e avenidas, nome de prédios, nome de fórum de debates, patrono. Mas, mesmo a elite à qual pertencia, a burguesia industrial paulista, jamais quis considerá-lo mais que isso. Guardou-o para ocasiões solenes ou para ocasiões difíceis, quando se tornava necessário um nome significativo para consertar situações críticas. Não se pode dizer que não foi levado a sério; foi, e justamente pela instituição que considerava, sem menosprezo, menos apta a adotar uma atitude operativa em uma política reformista e burguesa: a academia. 
Portanto, a imagem do Brasil no exterior no início da década de 1950 não correspondia de modo algum ao que aqui ocorria. $\mathrm{O}$ mito $\mathrm{JK}_{1}{ }^{44}$ do sonho da nova capital, também não foi outra coisa senão a continuidade da hegemonia da mesma elite que sempre soube agregar a seus interesses até mesmo manifestações eventualmente radicais de oposição.

Certamente, JK não era oposição a tal elite. ServiuIhe adequadamente e melhor: deu a todos a impressão de ser possível uma reforma amena, sem atritos, bem-humorada e gentil, a imagem que sempre gostávamos de ter de nós mesmos, brasileiros e narcisistas.

A vida de hoje nos desmente e desilude, pois não há mais a possibilidade de nos imaginarmos gentis e bem-humorados nas ruas do Rio de Janeiro e de São Paulo. Realmente, fomos os lentos criadores e céleres destruidores do mito do homem cordial, tão bem analisado por Sérgio Buarque de Holanda. ${ }^{45}$ Além disso, por trás do mito, sobrevivia um grave problema: o próprio enunciado do governo JK, seu maior slogan, os tão saudosos "50 anos em 5", por acaso já não nos diziam tudo? Que nada consistente poderia sair de tanta pretensão; que afinal cinco anos são apenas um detalhe, um mero orçamento, na vida de uma nação que todos sabiam problemática há mais de quatro séculos? Mas, não se pode negar que tudo isso gerou otimismo, simpatia, carisma, que duram até hoje; uma espécie de sebastianismo de uma grandeza prometida e não cumprida. E foi esse otimismo e essa simpatia que geraram em Bergmiller sua curiosidade pelo Brasil.

Mas havia a contrapartida. Os movimentos europeus de arte concreta eram, por sua vez, um interessante estímulo para artistas e designers brasileiros. Muitos se dirigiram para Ulm, até mesmo em função de saber que Max Bill, o grande premiado de nossa 1a Bienal, assumiria a direção de uma escola que poderia significar uma nova experiência pedagógica e que manteria vínculos com ideias progressistas e renovadoras. E para lá foram, entre outros, Alexandre Wollner, ${ }^{46}$ Almir Mavignier, ${ }^{47}$ Mary Vieira ${ }^{48}$ Yedda Pitanguy ${ }^{49}$ e Frauke Koch Weser. ${ }^{50}$ Próximo a esse grupo, Bergmiller interessou-se mais ainda pelo Brasil. Foi muito especial a amizade que surgiu com Alexandre Wollner e Almir Mavignier. Este permaneceria posteriormente na Alemanha. Wollner tornou-se, além de amigo, um companheiro permanente em diversos projetos e trabalhos. Sua participação no projeto da ESDI foi fundamental. Ao lado de Bergmiller, definiu e fundamentou os princípios que orientaram a fase inicial da Escola, particularmente os referentes à área da comunicação visual.

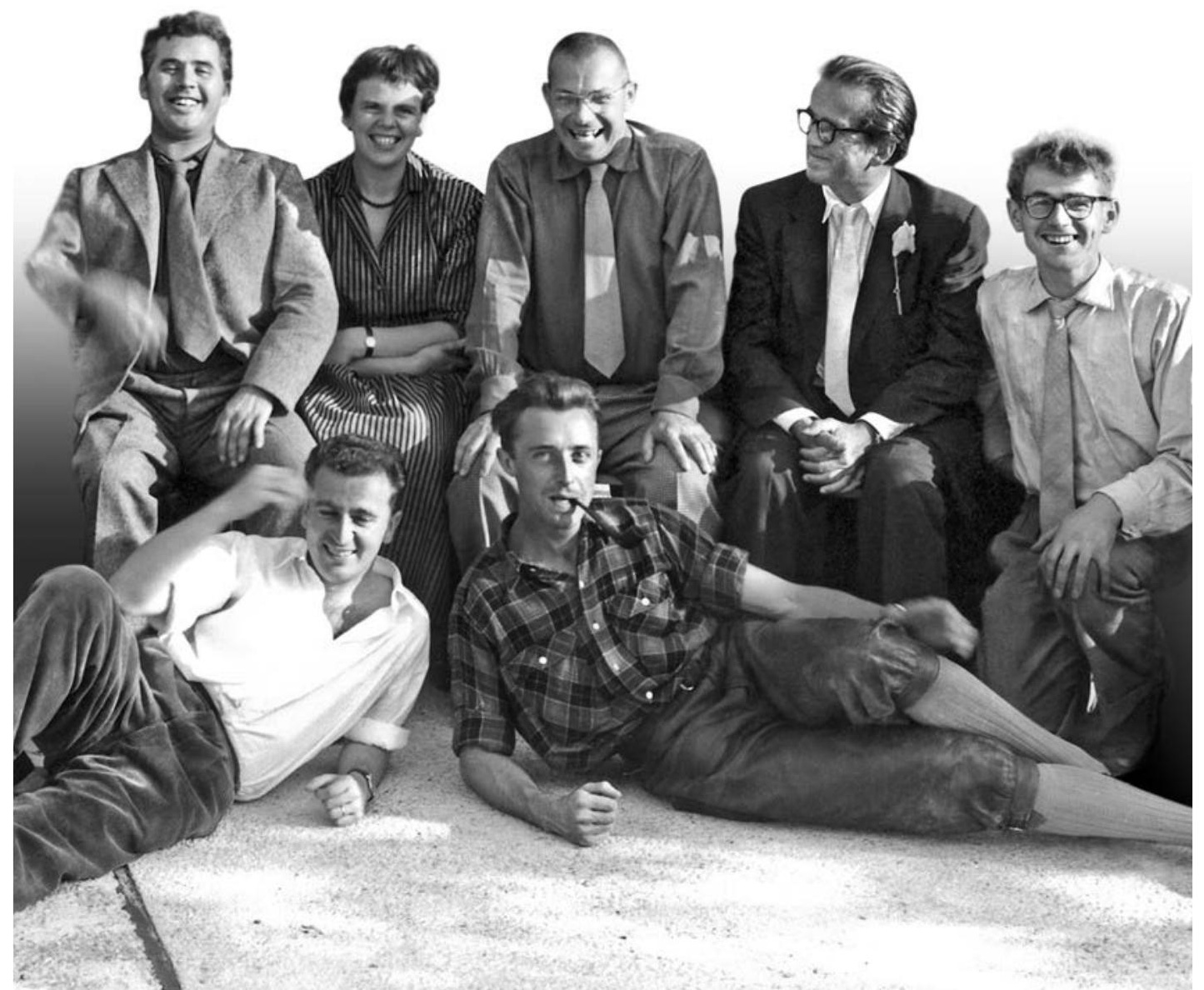

1.08.1956.

Aniversário de Inge Aicher Scholl. Detalhe de uma das várias fotos tiradas no terraço da Escola. Sentados 0t1 Aicher, Inge Schol1, Max Bi11, Konrad Wachsmann e Karl Heinz Bergmiller. No chão reclinados Alexandre Wollner e Christoph Naske. Foto MU HfG Archiv. Tratamento de imagem Helena de Barros. 


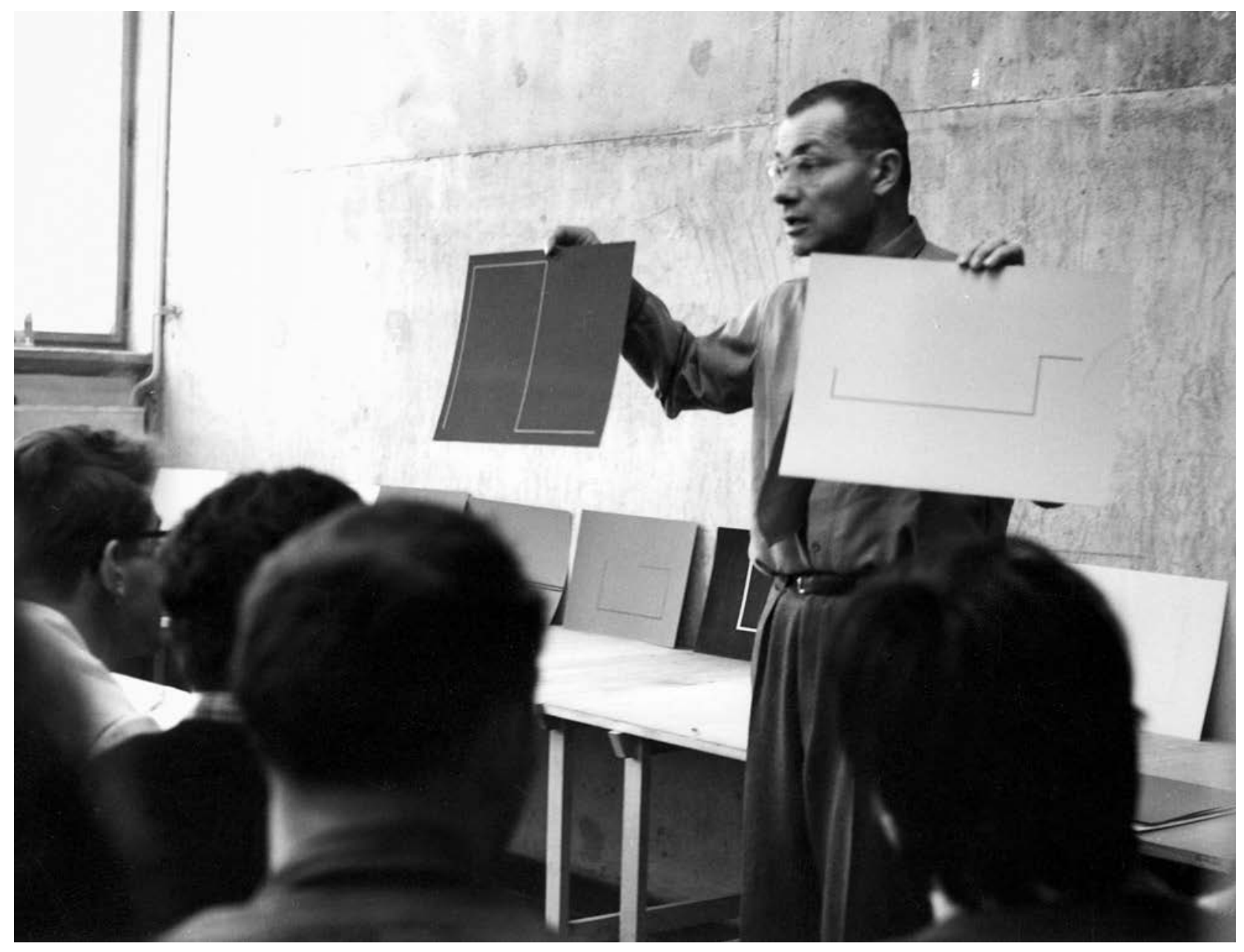

Max Bi11, 1956. Foto HANS CONRAD, MU HfG Archiv. 


\section{a influência de Max Bill}

Max Bill não era um modelo de professor revolucionário. Talvez apresentasse em sua personalidade e em sua atuação como professor muitos mais aspectos característicos de um mestre, de um artista, do que de um professor interessado na reestruturação de um mundo produtivo. Passou para a história do design moderno como exemplo de uma personalidade forte. Seus atritos com os professores chamados de 'mais jovens' não foram pessoais, mas ideológicos. Tais atritos já fazem parte, inclusive, de uma tradição nas escolas de design. Não foi uma repetição da questão ocorrida na Bauhaus entre Walter Gropius $^{51}$ e Hannes Meyer, ${ }^{52}$ mas, certamente, ambas apresentam muitos pontos em comum.

Bergmiller frequentou a Escola de Ulm dirigida por Max Bill, que regeu a Escola segundo concepções bastante rígidas. Ficou famosa sua resposta a uma reivindicação de alunos que consideravam um equívoco a presença de Nonnée Schmidt, professora em Ulm e, como ele, ex-aluna da Bauhaus: "Ela permanecerá...esta escola não precisa de alunos." É frequentemente lembrada também a importância muito particular por ele atribuída às questões de metodologias e técnicas de desenvolvimento de projeto. Mas, homem de poucas palavras e textos concisos, não se pode julgá-lo por uma espécie de quase anedotário criado a seu respeito. Nele, há um fundamento importante e uma notável influência de Mies van der Rohe. ${ }^{53} \mathrm{~A}$ questão do detalhe, a importância da coerência formal, sua própria definição de forma, a apreensão de conceitos que não são típicos da linguagem do design moderno, transformam-no num sobrevivente da guerra, sim, num ser de outro tempo, mas que traz em si e em sua obra alguma coisa que permanecerá. Tanto isso é verdadeiro que seria razoável afirmar que, sem sua presença em Ulm, as questões não teriam surgido com tanta clareza. Sem a sua personalidade, os professores liderados por Maldonado talvez não se sentissem obrigados a atitudes mais radicais, e as posições não tivessem ficado claras como se tornaram.
Mas, dentre as afirmações e os posicionamentos de Max Bill, precisos como seus detalhes, há elementos que vieram a ser pontos essenciais de discussão e outros que vieram a ser pontos de partida para concepções importantes do design na segunda metade do século XX. Algumas dessas ideias foram expressas logo no discurso inaugural da edificação da escola em 1955:

Os fundadores da HfG-Ulm acreditam que a arte é a expressão mais elevada da vida humana e seu objetivo é, consequentemente, ajudar a fazer da vida uma obra de arte. Nos termos dessa definição memorável, lançada por Henry van de Velde há mais de 50 anos, nós fazemos oposição ao que é disforme. E isto só pode ser combatido por aquilo que é bom. Bom significa belo e útil ao mesmo tempo. Como herdeira direta da Escola de van de Velde em Weimar, a Bauhaus de Dessau se atribuiu os mesmo objetivos. Se temos a intenção de seguir adiante em Ulm, o que não foi possivel em Dessau, é porque as exigências do pós-guerra implicam claramente a necessidade de certas adjunçôes ao programa de estudos. Queremos dar um lugar mais importante ao design de objetos de uso cotidiano; queremos encorajar o desenvolvimento do planejamento urbano e regional e levar a comunicação visual a um nivel correspondente aos últimos progressos técnicos. Haverá também um novo departamento para a coleta e difusão de toda a informação útil.

Todo o discurso era marcado por uma atitude típica de Max Bill, que considerava o Gestalter como o centro de qualquer processo de criação. A ele dever-se-iam subordinar as demais atividades envolvidas. A pouca importância que atribui ao novo departamento de informação, reduzindo-o a um banco de dados, não reflete uma concepção desinformada. É, isso sim, a percepção antecipada de que nessa área residiria o elemento novo capaz de questionar a ordem hierárquica por ele adotada, que compreendia o designer como um elemento central do projeto, devendo os demais profissionais 
envolvidos limitar-se ao papel de seus agentes executivos. Há ainda outros fatos a serem notados na ocasião da inauguração do prédio da escola: Walter Gropius foi um convidado de honra; e era de se esperar que o fosse. Mas, sua presença indica claramente uma intenção de não estabelecer uma ruptura com a Bauhaus e uma Bauhaus, em especial, que não era aquela imaginada por Hannes Meyer. A menção a Van de Velde tornava as coisas ainda mais claras, pois ninguém mais do que ele defendera em todas as ocasiões a posição autônoma e quase imperial do artista criador diante da técnica e mesmo dos fatores econômicos. Em apenas um parágrafo de seu discurso, Max Bill comunicava a todos que sua intenção não era abrir uma discussão a esse respeito: a autonomia do designer, do criador da forma, era para ele uma questão fechada. Diante de questões históricas, como os embates entre Henry van de Velde e Hermann Muthesius, no Deutscher Werkbund, e Walter Gropius e Hannes Meyer, na Bauhaus, ele tomava, sem nenhuma dúvida, o partido daqueles que não consideravam o design, a criação formal, como um território a ser dividido. Seu confronto com as concepções dos professores que julgavam necessário estabelecer bases mais concretas para o ensino, que não situavam o designer na condição de uma personalidade dominante, mas como um associado no processo de decisões da produção industrial, foi estabelecido desde o primeiro dia da existência da HfG-Ulm.

Bergmiller posicionou-se entre os seguidores de Max Bill. Porém, nunca o fez de forma incondicional. Relatou, diversas vezes, o quanto o impressionara favoravelmente o contato estabelecido a partir da presença em Ulm de Charles Eames ${ }^{54}$ e George Nelson, ${ }^{55} \mathrm{o}$ primeiro, a seu ver, um designer de primeira linha que poderia ser até mesmo comparado a Peter Behrens, ${ }^{56}$ entre os grandes nomes do século XX. O trabalho desenvolvido pelos dois para a Herman Miller ${ }^{57}$ marcou-o decisivamente quanto à possibilidade de um design integrado e programático, um design que se constituísse no elemento básico para o desenvolvimento de uma empresa, presente em todas as suas áreas de atividade, desde o projeto, passando pela produção e chegando até a comercialização e comunicação com os consumidores. Talvez ele nunca tenha se desligado totalmente da ideia de que o designer seria, se não o elemento centralizador desse processo, pelo menos o seu condutor. Mas, diante de evidências concretas, não considerou nunca em seu trabalho o designer como alguém que pudesse trabalhar isolado do complexo processo de inserção de produtos industriais na sociedade. $O$ trabalho em equipe interdisciplinar passou a ser para ele um objetivo importante e, ainda que mantenha pressupostos que poderiam ser encontrados também em Max Bill, relativos à autonomia do design, sempre admitiu a hipótese de que um projeto não é desenvolvido de forma autoritária pela personalidade do designer, mas mediante o estabelecimento de um conceito, da consideração de todos os dados objetivos possíveis que possam interferir em sua concepção.

Esta sempre foi uma forma relativamente simples que usou para estabelecer uma ordem determinada em seu trabalho: definir os dados objetivos e os dados subjetivos; considerando objetivos os dados possíveis de serem quantificados e subjetivos aqueles relativos à qualificação do projeto. Sempre achou também que, no território dos dados subjetivos, particularmente os formais, preponderaria sempre o designer, e essa seria uma de suas responsabilidades exclusivas. Dessa forma, Bergmiller evoluiu em relação a Max Bill, mas não se afastou de suas ideias básicas. É claro que o tempo e o trabalho, em especial quando se mede o tempo de maneira humana, ou seja, não o entendendo como prazo, modificam pensamentos e posicionamentos. Tentar encontrar Max Bill no trabalho de Bergmiller, no decorrer desse tempo, é tarefa de decantação, de apuro histórico. Ainda assim, percebe-se na atitude relativa ao design essa presença. Talvez se possa assinalar uma semeIhança notável nessa questão. Deduzo de suas narrativas sobre o relacionamento com Max Bill que este era uma pessoa relativamente centralizadora, capaz no entanto de atribuir grandes responsabilidades a seus colaboradores. Trabalhei com Bergmiller como estagiário, depois como colaborador, como associado e, por fim, estabeleceu-se uma relação de divisão de responsabilidades, principalmente a partir do IDI/MAM. Mas, desde a época de estagiário, impressionava-me sua disposição em atribuir-me trabalhos para os quais eu não me sentia ainda habilitado. Admitia poucas perguntas depois de atribuir tais tarefas. Discutia os resultados apresentados, mas o fazia de forma amena, nunca condescendente com o que considerava errado, e sim entendendo que o erro fazia parte, não propriamente do processo de aprendizado, mas do processo normal da vida. Anos depois, 
imerso na leitura preferida de sempre, Merleau-Ponty, descubro um conceito no pensador francês que servia perfeitamente para definir essa atitude: "verdade faIhada". Não haveria erro se as intenções tivessem sido estabelecidas a partir de elementos corretamente considerados. $O$ erro seria uma possibilidade apenas diante do descaso ou da insensibilidade. A "verdade falhada" seria sempre o espaço generoso para com os outros e, por que não para consigo mesmo, que permitiria a retomada sem traumas do processo criativo. Também nesse aspecto percebia-se sempre a influência de Max Bill, provavelmente com mais humor e menos personalismo, mas, de todo modo, preservando ainda uma relação de mestre e aprendiz que foi desenvolvida até seu estágio final.

Não afirmo ser esse um relacionamento fácil. Os mais jovens se fazendo, como dizia Mário de Andrade, têm também a tendência a criar suas próprias formas de arrogância, e isso não é um fenômeno contemporâneo. Pertenço a uma geração que manifestou bem alto suas ideias em 1968, outra de nossas mitologias, geração revolucionária que, já há algum tempo, tem alguns de seus elementos de destaque em áreas importantes do poder, sem que absolutamente nada tenham feito para modificá-lo em sua essência. Mas não somos nós o problema aqui tratado. Falamos da outra geração, a que nos antecedeu, aquela que criticamos e na qual, muitos de nós encontramos todas as justificativas para que nossas ideias não dessem certo. Não podemos também proclamar uma autocrítica radical; não podemos afirmar que afinal eles é que estavam certos e que toda a nossa rebeldia não passou de um problema juvenil. Gosto de uma ideia e de uma frase de Nelson Rodrigues ${ }^{58}$ que diz ser a juventude um problema que o tempo cura. Não a aceito irrestritamente. Mas, se alguma coisa a mais aprendemos com eles foi a tolerância, ainda que sujeita a recíprocas tempestades de humor. Talvez nunca tenha havido um grupo de professores tão contestado no ensino superior brasileiro como o da ESDI em 1968. Estive entre os rebeldes e, por minha própria personalidade e posicionamento ideológico, discordava deles também. Formulamos ideias, apresentamos propostas, estabelecemos posições radicais, ultrapassamos limites e isso, no mínimo, fez bem a nossa alma. Quem não o fez perdeu o que de melhor tivemos. Ao ultrapassar os limites, recebemos uma resposta inesperada: nenhuma punição, nenhum apelo à ordem ou à disciplina, mas argumentos que podiam não ser satisfatórios para o nosso radicalismo, mas ainda assim argumentos. Nesse grupo de professores encontravam-se, além de Bergmiller, personalidades como Aloísio Magalhães, Alexandre Wollner, Goebel Weyne, ${ }^{59}$ Renina Katz, ${ }^{60}$ Décio Pignatari, ${ }^{61}$ Zuenir Ventura $^{62}$ e tantos outros. Cada qual a seu modo reagiu aos fatos, uns de forma mais elaborada, outros de forma mais rude. Mas, não me lembro de nenhum que apelasse para os princípios da autoridade e da hierarquia como elementos válidos naquelas circunstâncias. Bergmiller exercia não apenas uma liderança grande naquele grupo, como assumia também uma responsabilidade maior na formulação do ensino. Era, ao lado de Aloísio, uma referência importante da Escola. Poderíamos esperar dele, mais que de Aloísio, uma atitude autoritária que não veio. Houve uma disposição para a discussão que, afinal, não foi nem amena e nem produtiva. Mas, nesse aspecto, ele se diferenciou totalmente de Max Bill. Não buscou refúgio em princípios de difícil compreensão. Manteve-os, expôs-se, mas não se furtou à discussão. Três anos depois me tornei estagiário da Bergmiller Desenvolvimento de Produtos Industriais e pude, de forma mais tranquila, conversar sobre tudo isso. Surpreendi-me, pois ele achava que em muitas críticas os alunos tinham razão. Lamentava principalmente a oportunidade perdida, e o foi, ambos reconhecemos a posteriori, para que se tivesse desenvolvido uma nova alternativa, na qual, pelas próprias circunstâncias, os alunos teriam de assumir responsabilidade igual a dos professores.

Talvez não percebêssemos na época que tal possibilidade era apenas uma ilusão; que os problemas estavam em nós, mas que a alternativa havia-nos sido escamoteada por outros, os militantes da política do poder e da burocracia, que acabam sempre por convencer a todos dos perigos de uma mudança, da fragilidade da instituição, da possibilidade de um amplo acordo que garanta a sobrevivência geral, da necessidade de que o silêncio prevaleça e de que a discordância não se manifeste. É assim que se domesticam as ideias novas, que se conduz ao chiqueirinho das crianças malcomportadas tudo o que pode pôr em risco um mundo regido pela hierarquia de um poder tradicional e patriarcal. Foi assim que se encaminhou uma escola renovadora, rebelde até, para o destino do consensualismo, uma prática que, 
longe de estabelecer princípios gerais, busca apenas acordos comodistas em torno de ideias vagas.

Mas, afinal, essas não são mesmo decisões fáceis, e o exemplo de Ulm, antes uma referência, passou a ser também a possibilidade de um caminho perigoso para muitos, o caminho da autoextinção. Há alguns anos me referi a esse fenômeno como o preço da sobrevivência e as analogias políticas eram muitas e evidentes. Aos consensos da escola correspondiam os consensos da política geral. A ESDI, assim como suas antecessoras, seus modelos ansiados, tentou, sim, interferir na vida política do país, e não é importante analisar agora se houve erros ou acertos. Coloquemos tudo no grande cesto das "verdades falhadas". Ao optar pela sobrevivência, abandonou esse posicionamento e o preço é, a meu ver e até hoje, muito alto. Até porque ninguém mais o reivindicou, e o design permaneceu compreendido, cada vez mais, como uma atividade limitada às questões técnicas, ergonômicas, de uso e formais, um assunto a ser tratado com palavras vazias como 'tendências', num linguajar televisivo. Muito pouco resultado para tanto empenho de vida.

Todo o episódio serviu para marcar uma diferença essencial entre Max Bill e Bergmiller que, afinal, não reside propriamente no design, mas nas respectivas personalidades. Como já foi dito, Maldonado um dia falou que houve discordância quanto às questões pedagógicas em Ulm, mas que os resultados formais não foram em nada diferentes do que preconizava o artista e designer suíço. Se as personalidades de Bergmiller e de Max Bill eram diferentes, seus conceitos básicos de design permaneceram muito próximos. A diferença se estabelece no tempo, nas gerações e nos fatos políticos. Se Max Bill foi um homem formado antes da Segunda Guerra Mundial e que permaneceu ainda apegado a algumas ideias anteriores ao conflito, Bergmiller faz parte da geração que a viu acontecer jovem e a quem foi proposta uma reconstrução, e não uma restauração. Desse modo, ainda que de forma seletiva e exclusiva, ele sempre foi capaz de se apropriar do novo, do que lhe parecia interessante, como, por exemplo, da experiência da Eames e Nelson na Herman Miller, pois no final das contas o que se queria fazer em Ulm acabava acontecendo, ainda que excepcionalmente, nos Estados Unidos.
Voltemos um pouco a Max Bill e sua definição de forma: Forma é o que encontramos no espaço. Forma é tudo o que podemos ver. Mas, quando ouvimos a palavra forma ou refletimos sobre o conceito de forma, ela significa para nós algo mais que uma coisa que existe casualmente. Desde o princípio associamos o conceito de forma a uma qualidade. Quando falamos de formas naturais, pensamos naquelas particularmente bem-sucedidas. Quando falamos das formas técnicas, não nos referimos a quaisquer formas, mas àquelas que consideramos especialmente válidas.

Em outra ocasião, considerei importante acrescentar a esse outro trecho do livro de Tomás Maldonado: Max Bill. (Buenos Aires: Imprenta Lópes,1955), no qual é o próprio Max Bill quem esclarece que a reivindicação de novas formas não inclui o apelo ao streamlining. ${ }^{63}$ Considero desnecessário aqui tal reforço. Não apenas porque suas ideias já ficaram suficientemente claras, como também porque o styling ${ }^{64}$ adquiriu outras formas e conotações diferentes, mesmo fora do território restrito do design, instalando-se até na personalidade e formas de condução da política contemporânea globalizada. Haveria algo mais styling, mais kitsch, ${ }^{65}$ que as personalidades de George W. Bush e Tony Blair por um lado e os reis sauditas, Osama Bin Laden e Sadam Hussein, de outro?

$\mathrm{Na}$ afirmativa de Max Bill residem muitas coisas interessantes. Poderíamos criticar, hoje, uma concepção de natureza um tanto restrita. Afinal poderíamos pensar que toda forma natural é em si necessária e útil, pois de outro modo desapareceria. Talvez o próprio Tomás Maldonado já o tenha feito há muito tempo, quando chamou a atenção para a obra de D'Arcy Thompson ${ }^{66}$ a respeito do crescimento e desenvolvimento das formas naturais. Há na concepção de Bill uma nítida marca do tempo em sua compreensão de natureza. Porém, quando se refere a formas especialmente bem-sucedidas e estabelece uma relação com as formas técnicas, ele está dizendo claramente duas coisas: em primeiro lugar, que fazer design é uma forma de qualificar um produto; em segundo lugar, talvez o mais importante, não há um bom ou um mau design: há ou não há design. E esses conceitos permanecem em Bergmiller. Eu também os aceito e acho que uma breve reflexão sobre eles elucidaria muito o árduo e inútil trabalho de elaborar ideias relativas sobre o que é design. Perguntar isso 
significa, como me dizia um velho professor de matemática, "procurar chifres em cabeça de égua". Pensar apenas em produtos e objetos, em peças gráficas conduz a tais contratempos. Entender o design como uma atitude e, além disso, como uma atitude de qualificação dos objetos, dos processos, da própria vida, pode facilitar muita coisa. Essa concisão presente em Max Bill permanece em Bergmiller.

Finalmente a maior diferença entre eles aparece em sua definição profissional. Em Max Bill, mesmo constatando sua multifacetada atuação - designer, arquiteto, gráfico - prevalece sua atitude de artista, de homem que imagina a si mesmo como dono de sua expressividade, como um indivíduo entre outros, mas com o direito de fazer prevalecer sua individualidade. Quanto a Bergmiller, ele é designer. Sabe que sua individualidade é também uma entre outras; mas que, para fazer prevalecer suas ideias, precisa não só convencer os outros mas também ser apoiado por eles. Em outra de suas frases características, ele dizia: "Faça design de uma forma que até a sua avó entenda". Talvez por isso ele tenha se autodenominado, um dia, um designer mais preocupado com as cabeças do que com objetos.

Não há como fugir à evidência de que Max Bill era um caráter difícil. Ao que parece, no entanto, considerando-se as narrativas e as conclusões a partir dos fatos, um caráter difícil não era raro em Ulm. Ainda estamos à espera de ouvir falar de alguém que lá apresentasse uma personalidade menos complexa. Seu maior interesse pessoal era a arquitetura. Apresentava-se como max bill architekt, mas sua maior importância terminou concentrando-se na escultura. Tornou-se comum ouvir dizer que Bill era muito mais difícil do que eventualmente fosse, de fato. A dissolução de um grupo criativo apresenta esse tipo de problema. Porém, deve-se ainda considerar que muitas pessoas que dele fizeram parte foram particularmente bem-sucedidas profissionalmente, e o foram por diversas razões, inclusive seus próprios méritos e competências. Parece um tanto simplista a constante crítica a Max Bill. Não se pode atribuir apenas a ele os problemas iniciais da Escola, o que, aliás, o próprio Maldonado não o faz. Maldonado iniciou sua vida, na área do design em Ulm, muito em função de suas divergências com Bill. Nos contatos que mantive com ele, nunca percebi qualquer deselegância de sua parte em relação a Max Bill. Sempre me pareceu manter uma atitude crítica, porém objetivando uma progressão nas ideias sobre o design. Se tem ou não restrições ao caráter pessoal de Bill, não as eleva ao primeiro plano e, nessa circunstância, torna-se objetivo a ponto de admitir que a influência formal do suíço foi o referencial para a definição do que se poderia chamar, impropriamente, de um estilo Ulm. E não terá sido exatamente esse estilo, essa caracterização formal definida por Charles Jencks como uma "estética da reticência", que também deu à maioria dos designers de Ulm as referências para seu trabalho? Olhando o design por eles produzido não vemos claramente a interferência do mestre?

Nesse processo de reflexão bastante livre, é importante ler o depoimento de Bergmiller sobre Max Bill e sobre as influências em sua formação na época de Ulm: Em muitas publicaçôes sobre a HfG-Ulm, Max Bill é descrito como um caráter difícil, arrogante, mal-humorado, centralizador, até mal-educado. Outras interpretaçóes existem ainda sobre as suas divergências com o grupo que a ele se opôs na escola. Acho que é uma boa ocasião para definir algumas opinióes minhas sobre Max Bill, de forma um pouco diferente, e quem sabe mais simpática. No que me concerne, ser totalmente objetivo nessa questão não é possível, uma vez que era aluno, colaborador, amigo e admirador de Max Bill.

Em uma conferência para o Werkbund na HfGUlm, em 1956, Max Bill defendeu um processo morfológico no desenvolvimento de produtos, um método que possibilita interpretar os fatores de ordem estética como uma função, resultando na conhecida definição "a Gestalt como soma de todas as funçóes em uma unidade harmônica".

Esse método pode ser aplicado tanto para o projeto de uma colher de sopa como para um projeto urbanístico. Para alguns dos presentes do Werkbund, isso soou como uma provocação e Max Bill era por natureza um provocador. Era um artista de vanguarda, sempre surpreendente e provocador. Utilizou a análise morfológica inclusive em sua produção artística e, não sendo um artista comum, sempre chamou sua arte de "produtos de uso psicológico", diferenciando-os dos de uso prático, que seriam de responsabilidade dos arquitetos e designers. Max Bill oscilou constantemente entre teoria e realidade, mas sempre buscou a capacidade de fazer afirmações teóricas e conceituais e prová-las na prática. 


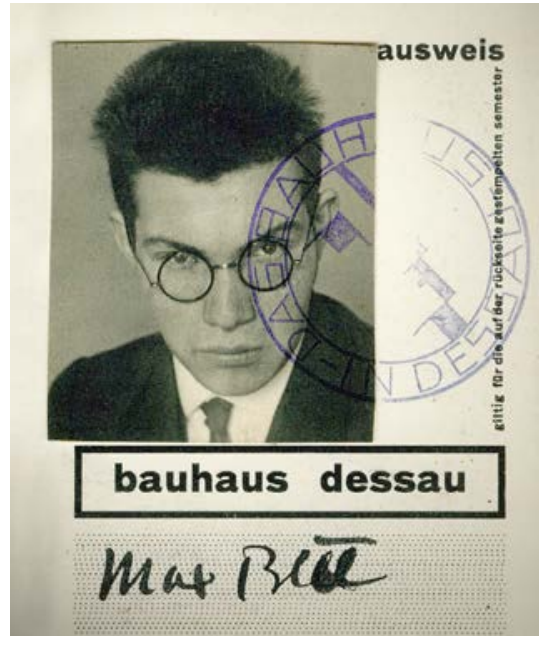

O grupo oposto às suas concepções interpretou-as como uma continuidade de princípios da Bauhaus, o que é uma ideia um tanto naif. Desde o início da HfGUlm, ficou muito claro para todos que entre o fechamento da Bauhaus, em 1933, e a fundação da HfG-Ulm, no início dos anos 50, a tecnologia e as demandas sociais mudaram e, por isso, os programas de ensino deveriam apresentar estruturas diferentes, sem, contudo, deixar de lado os valores e os méritos dos métodos de ensino desenvolvidos na Bauhaus. Nunca se postulou como objetivo da HfG-Ulm uma continuação, mas sempre uma evolução. Para Max Bill, seria sempre necessário desenvolver e salientar a importância das questões estéticas e formais em qualquer área da criação.

Max Bill era um artista conceituado e sentiu-se à vontade, quase no direito de interpretar os conceitos da nova escola à sua maneira, como um "artista total", como o chamou o próprio Tomás Maldonado alguns anos antes. Mas, acho que nesse processo não demonstrou suficiente paciência e tolerância em relação aos seus jovens colegas. Mas, é importante salientar que nas interpretações surgidas nos últimos anos, essa expressão, 'jovens colegas', tem sido usada e fica a impressão de que havia uma grande diferença de idade entre Max Bill e os que a ele se opunham. Ele tinha na época 45 anos, e Maldonado e Aicher tinham quase 35 anos. Não havia uma oposição de jovens contra velhos, exatamente. Não se poderia ver nessa situação um choque de gerações.

Max Bill sempre contou com o apoio da maioria dos alunos e de grande parte dos professores. Mas quando tudo se transformou em uma briga de forças políticas pelo poder, não mais um conflito de conceitos pedagógicos, ele não era, de modo algum, uma pessoa apta a enfrentar as questões nesse território. Nesse processo, infelizmente, não prevaleceram os objetivos básicos da instituição. A imprensa, como sempre faz nessas situações, aproveitou para jogar mais lenha na fogueira, até mesmo porque uma instituição renovadora como a HfG-UIm nunca foi vista com muita simpatia pela burguesia local.

O clima que se criou na HfG nessa época lembra-me da fase que passamos na ESDI, em 1968, e a pergunta que podemos fazer hoje seria a mesma para todos: nós, ex-alunos da HfG-Ulm perdemos durante essa fase de divergências ou aprendemos algo mais? A mesma questão pode ser formulada para os ex-alunos da ESDI de 1968. A meu ver, mesmo sem considerar a resposta que cada um possa dar individualmente, perderam apenas aqueles que tiraram o corpo fora ou se mantiveram passivos diante dos acontecimentos e das circunstâncias.

Max Bill não foi um professor ortodoxo. Concentrava suas conceituações mais importantes, suas definições mais inovadoras, em conferências, algumas delas históricas. Definiu problemas básicos e inovadores no Curso Fundamental e estabeleceu um sistema inovador para a posterior discussão dos resultados. Era uma forma de avaliação diferente, às vezes durava vários dias, adquiria uma forma dinâmica e era um excelente exercício para o aluno apresentar e defender suas propostas. Max Bill nunca fez prevalecer a sua opinião. Para mim e para muitos de meus contemporâneos, essa foi uma das primeiras grandes lições que marcaram nossos estudos na HfG-Ulm.

Max Bill não era uma personalidade fácil, mas tinha uma característica importante que era sua capacidade de atrair as pessoas. Nos seus anos de Ulm, foi um verdadeiro polo magnético, atraindo para lá personalidades internacionais para participar ativamente como professores ou conferencistas da Escola. Conseguiu ainda apoio em setores empresariais, no meio político, na imprensa mais especializada e em várias instituições culturais. Mesmo Maldonado, Gugelot, ${ }^{67}$ Zeischegg e Herbert Ohl, ${ }^{68}$ que formaram mais tarde com Aicher o bloco em sua oposição, foram convidados por ele. Em política as coisas são assim e, por isso, hoje, não vejo nada de muito especial nisso. Os anos nos ensinam muita coisa, principalmente a tolerância. 
Mas a HfG mudou, evoluiu depois da saída de Max Bill? Acho que sim, definiu-se mais em vários sentidos, principalmente nos conceitos de metodologia do ensino, tudo em um período muito curto. O que teria acontecido se Bill permanecesse à frente da Escola são apenas hipóteses e meras conjecturas.

Restam algumas perguntas. Por que a Escola encerrou suas atividades? Faltaram recursos, faltou sabedoria política, faltaram ideias, faltou vontade, faltou autocrítica? Provavelmente de tudo um pouco. Ou todos ficaram satisfeitos com uma afirmação muito duvidosa, com o argumento de que "uma instituição de vanguarda nunca resiste durante um período muito longo"? Essa afirmação merece uma análise à parte, muito crítica e, acima de tudo, muito rigorosa.

É importante lembrar que a maioria dos alunos e muitos professores sempre manifestaram seu apoio a Max Bill, porém a Geschwister Scholl Stiftung, mantenedora da Escola, fez prevalecer sua vontade, jurídica, pode-se dizer, e ele não foi mais designado como diretor da instituição. Permaneceu ainda algum tempo, sendo-lhe reconhecido o direito de concluir as orientações de projetos de formatura e outras atividades. Mas, em pouco tempo, ele afastou-se da Escola definitivamente. Assim, Max Bill já não era mais integrante pleno do corpo docente da Escola na época de meu Diplomarbeit. Mas tive a prerrogativa de ser orientado por ele até o final, assim como alguns outros colegas. A banca examinadora, convidada e presidida por ele, tinha nomes de peso do design.

Trabalhei durante dois anos no Ateliê Max Bill. Esse ateliê, foi assim que ele o chamou, era um estúdio dentro da Escola, para desenvolver trabalhos concretos encomendados por empresas. Essa era uma atividade prevista nos estatutos do Institut für Produktgestaltung. Fui admitido com mais três colegas, no Ateliê, depois de ter me candidatado, respondendo a um comunicado no quadro de avisos da Escola. É claro que apareceram muitos candidatos e os critérios para a seleção eram o bom rendimento no curso e também o tipo de conhecimento técnico que tínhamos para oferecer. Tive sorte e fui escolhido. Cada um dos quatro integrantes do Ateliê desenvolveu projetos reais, encomendados por empresa europeias, desenvolvidos sob a supervisão de Max Bill e com apoio técnico da própria empresa contratante. Desenvolvi uma luminária de mesa, uma central telefônica e um telefone de mesa. Meus colegas desenvolveram relógios, assentos de trabalho e poltronas para auditório. Estava nos planos do Ateliê o redesenho de um automóvel para a Porsche, com a participação de um neto de Ferdinand Porsche, na época, aluno da HfG.

O relacionamento com Max Bill era sempre muito respeitoso, mas também cordial. Dentro da Escola nossa atividade foi a que mais rapidamente resultou em trabalhos reais, gerando alguns ciúmes e deu espaço a conflitos e ao argumento de que se estaria fazendo uma escola dentro da Escola. Várias vezes viajei com Bill para a Suíça e outros lugares, como para a montagem da exposição de Piet Mondrian, para a inauguração do Cinevox, ambos os projetos seus. Fizemos ainda visitas a outros eventos, exposições e clientes, sempre de Bentley, um carro primorosamente fabricado. Quando concluí os estudos, recebi um convite de Max Bill para trabalhar em seu escritório em Zurique. Mas, por causa da bolsa de estudos do governo brasileiro, não podia aceitar. Manifestei interesse, no entanto, em trabalhar lá quando voltasse do Brasil, o que afinal não aconteceu. A caminho do Brasil, tinha de embarcar em um navio, em Gênova, parei em Zurique para me despedir e homenagear o mestre. Entreguei-lhe um relatório ilustrado sobre o desenvolvimento do telefone de mesa realizado no Ateliê Max Bill e recebi o livro Max Bill editado em homenagem aos seus cinquenta anos.

Durante um bom tempo mantivemos correspondência. Relatava principalmente como era a minha estada e a minha vida no país. Depois, virei brasileiro e, como me esclareceu uma vez meu colega Almir Mavignier, em Ulm, "só os poetas brasileiros escrevem cartas". Voltei a encontrá-lo na Europa várias vezes, em Zurique e em Hamburgo. Chegamos a combinar a realização de uma exposição a ser realizada trinta anos depois de sua premiação na Bienal do MASP. Lembrou-se com muita simpatia do Brasil e disse que estava disposto a entrar no projeto, desde que eu assumisse sua coordenação no Brasil. Os diretores do MAM/RJ69 mostraram interesse, mas o apoio real foi insuficiente.

Max Bi11. Detalhe do cartão de identificação de estudante: Bauhaus Dessau, 1927-1928. 


\section{a formação em Ulm}

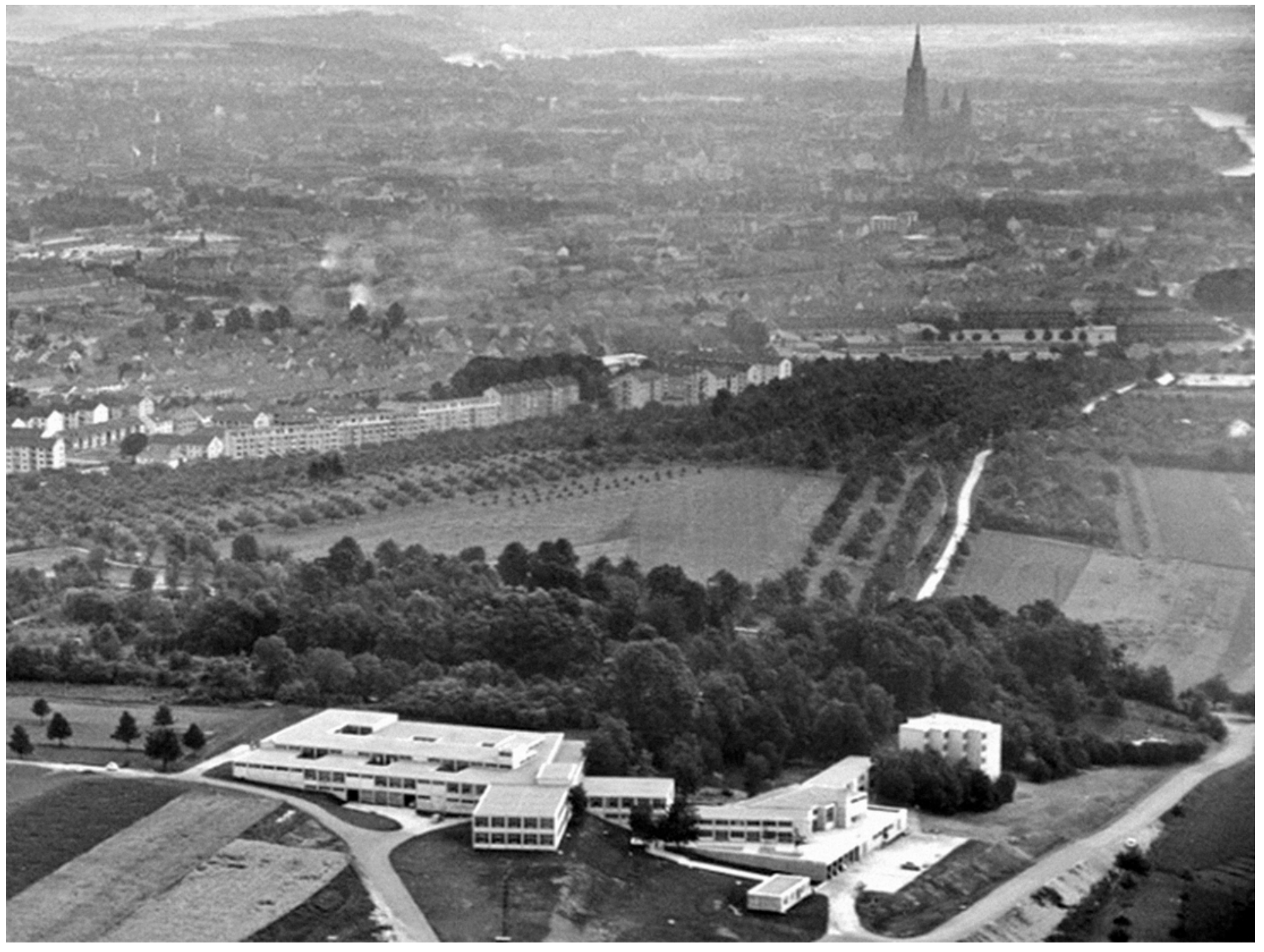

Foto aérea com a Escola em primeiro plano

e a Catedral ao fundo, agosto de 1955.

Foto OTL AICHER, MU HFG Archiv. 
Ulm era uma espécie de mosteiro, fora da cidade, em cima de um morro. Lá viviam os mestres, os colegas, as personalidades que vinham de fora, de todas as partes do mundo, diferente do que estávamos acostumados, mas coerente com os propósitos da instituição. Eram quatro anos de vida em comum, muito intensos. Uma referência tipica do que era a Escola foi o banquinho de Ulm. É difícil imaginar um assento mais elementar: três tábuas de pinho e uma travessa como um cabo de vassoura, fabricado dentro da própria oficina da Escola. No início, foi destinado "um banquinho por cabeça" e, sendo assim, cada um carregava seu banquinho para a sala de aula, o auditório, o refeitório e o quarto. Anos depois, observei na África homens carregando um banquinho no ombro, e me contaram que eles ganhavam esse objeto de uso pessoal ainda meninos e que os usavam até o fim da vida. Em algumas tribos, havia até o ritual de, ao morrerem, serem enterrados com seu banquinho. Alexandre Wollner carrega até hoje o seu banquinho de Ulm. Ele tinha duas alturas para sentar: 40 ou $45 \mathrm{~cm}$. Servia também como mesinha. Era confortável, correto em questóes ergonômicas? Ora! A exigência número um era ter um assento básico, econômico e de um feitio tecnicamente correto e formalmente impecável.

Encontrar alguma coisa assim na Alemanha pósguerra não era possivel. Max Bill imaginou e criou um objeto coerente com os conceitos e teorias estabelecidas por ele mesmo. E nesse espírito tudo foi concebido na Escola: os prédios, as instalaçôes, os móveis, a iluminação, o paisagismo, tudo em coerência e em harmonia. Até mesmo as questóes referentes à alimentação entraram em discussão nessa época.

Costuma-se pensar que Ulm é uma ideia tipicamente alemã. O que até certo ponto é correto. Mas a maior parte das pessoas que lá estudaram ou deram aula não eram alemãs. Penso que Ulm é produto de circunstâncias que ocorreram na Alemanha, mas não é o estereótipo da ideia de 'alemã' que se quer dizer. As influências em Ulm, na formação de qualquer um que lá tenha estudado, davam-se sobretudo pelo próprio ambiente que possibilitava uma total concentração de interesses no design e nas questóes pedagógicas. Mas é claro que alguns professores foram especialmente significativos para mim. Max Bill era a principal personalidade em Ulm, e eu tive o privilégio de trabalhar diretamente com ele. É claro que foi quem mais influenciou meus estudos; depois, meu trabalho profissional e também minhas ideias sobre ensino, pois seus conceitos estavam presentes na época da estruturação da ESDI. Posso dizer que até os dias de hoje seus argumentos são importantes para mim. O que mais me impressionou em Max Bill foi sua forma exata de se expressar, sem nenhum virtuosismo intelectual, sem nenhum pedantismo. Às vezes, seus argumentos surpreendiam e poderiam indicar caminhos para um produto primitivo. Mas, quando se refletia sobre eles, percebia-se que não eram nada primitivos: eram essência. Deveria ser um produto do qual "não se deveria tirar nada e também nada acrescentar".

Outra influência importante foi Josef Albers, ${ }^{70}$ ex-aluno e professor da Bauhaus, que emigrou para os Estados Unidos em 1933, lecionando no Black Mountain College. ${ }^{11}$ Realizou em Ulm um curso intensivo com um tema muito abrangente sobre cor e estruturas. Em relação ao curso anterior de Johannes Itten, também professor da Bauhaus e um dos idealizadores do conceito de Curso Fundamental, havia uma notável diferença: Itten usava para os exercícios cromáticos pigmentos, tintas; e Albers, menos convencional, empregou em suas aulas exclusivamente materiais já existentes, comuns, como papel de embrulho. Seu objetivo era fazer que os alunos "percebessem e descobrissem". Josef Albers tinha uma capacidade de motivação única e jamais se estratificou como professor, nunca parou no tempo da Bauhaus. Foi provavelmente o melhor professor em sua área em todo o mundo.

Walter Zeischegg foi outra influência importante. Trabalhei com ele durante algum tempo antes de ir para o Ateliê Max Bill. Desenvolvi um projeto de iluminação de vitrines para a Phillips. Zeischegg era escultor e designer, austríaco, tinha conceitos muito rigorosos e aplicava uma autocrítica radical em sua atuação profissional. Isso o levou a produzir relativamente pouco, mas o que ficou é de uma qualidade excepcional.

Havia um professor menos conhecido em Ulm, Werner Blaser, ${ }^{72}$ arquiteto e designer suiço, que havia trabalhado com Mies van der Rohe e Alvar Aalto. ${ }^{73}$ Era também colaborador de Max Bill e desenvolveu pesquisas no Japão sobre as formas tradicionais de construção em madeira, especialmente nas casas de chá, descobrindo a verdadeira genialidade de suas soluções. Depois publicou um livro sobre o assunto: Structure and Form, in Japan: architectural reflexions. (Scarsdale, New 
York: Wittenborn and Company, 1963). Criou móveis dentro desses padrões. Na Escola, seu curso sobre juntas e conexões era breve e sem grande influência. Mas para mim ficou clara, até hoje, a ideia de que o detalhe construtivo inteligente de um móvel identifica bem a qualidade do produto.

Konrad Wachsmann,$^{74}$ outra influência importante na Escola, foi professor de pré-fabricação e já havia desenvolvido um trabalho sobre grandes estruturas nos Estados Unidos, onde era sócio de Walter Gropius. Ele mostrou em Ulm duas coisas fundamentais: a forma de conduzir pesquisas complexas em grandes equipes, com profissionais de diversas áreas e a importância do que ele chamava de "nó construtivo", das uniões, juntas e conexões. A partir desses "nós", desenvolvem-se mesas, abrigos, galpões, pontes, hangares para aviões, qualquer construção para diversos usos. Talvez ninguém tenha deixado tão clara a noção de sistematização na construção.

Essas foram as influências mais diretas que recebi durante meu tempo de estudante em Ulm. Mas é importante frisar novamente que o ambiente da Escola era propício a que todo aluno pudesse observar e acompanhar o que os demais grupos projetavam e produziam. Os próprios colegas influenciavam uns aos outros. Eram pessoas de formações diversas, de diferentes países e culturas, no entanto com a mesma obstinação: queriam criar e achavam que com isso poderiam mudar o mundo. Se isso pode soar hoje como uma pretensão radical, como uma utopia, não acho nada demais. Era próprio da juventude. Mas não se pode esquecer que o próprio Mies, que já não era nada jovem, recomendou uma vez: "Murro na mesa, rapazes, se o pessoal não quiser entender, murro na mesa".

No ensino, em qualquer área, uma seleção especialmente cuidadosa dos alunos é essencial para a obtenção de bons resultados. Se houver esse cuidado, os alunos serão exigentes e difíceis. A vantagem é que docentes fracos não conseguem trabalhar grupos exigentes. Por outro lado, de nada adianta ter um corpo docente qualificado e turmas de alunos desinteressadas, superficiais e dispersivas. Na HfG-Ulm muitos colegas já eram profissionais formados em diversas áreas e a troca permanente de informações e experiências contribuíam para enriquecer o conhecimento de cada um. A constante motivação de justificar a própria presença na Escola resultou em uma competitividade saudável, tanto individualmente como nas equipes de trabalho. Estou cada vez mais convencido de que o principal aprendizado em Ulm foi devido a essa convivência.

A HfG-Ulm proporcionou essa experiência realmente inédita. Mas, talvez sua maior qualidade tenha mesmo sido a de não se preservar apenas como instituição, e é nesse aspecto que mais uma vez ela se caracterizou como um grupo criativo. As pessoas e suas diferenças e divergências devem ser tão importantes quanto a própria instituição e, se esta não pode mais abrigá-las, torna-se não funcional. A imposição inicial da Fundação Scholl para a saída de Max Bill da direção não foi diferente quando ela agiu para a posterior marginalização de Maldonado. A exemplo do que ocorreu na ESDI, depois de 1968, com a introdução e a valorização de aspectos mais institucionais do que programáticos, podese estabelecer uma crítica paralela ao desempenho da fundação em Ulm. Propôs-se uma política de consensos. A diferença está que na ESDI ela foi aceita e adotada, ao passo que em Ulm isso não ocorreu. Restam as desculpas e os conformismos. Na ESDI, criou-se o hábito de culpar a burocracia pelos próprios problemas; em Ulm, como ressalta Bergmiller, adotou-se a ideia de usar o vanguardismo como refúgio para um fracasso que não houve. E, como já perguntou Oswald de Andrade, "O vanguardista está na frente de que corrida?"

Nesse aspecto as duas escolas continuaram semeIhantes e gerando seus próprios discursos mitológicos, com uma diferença favorável a Ulm: um mito desaparecido passa a permitir múltiplas interpretações, pois sobrevive nas mentes, e não na vida prática. Um mito que se quer vivo, caso da ESDI, vê-se obrigado a sustentar essa difícil posição no cotidiano e tem assim de sobreviver na vida prática e enfrentar as mentes vivas que, muitas vezes, não estão nem um pouco interessadas em seu próprio dia a dia. Mas, como diria Guimarães Rosa, em Tutameia: "e pôs-se a fábula em ata." 


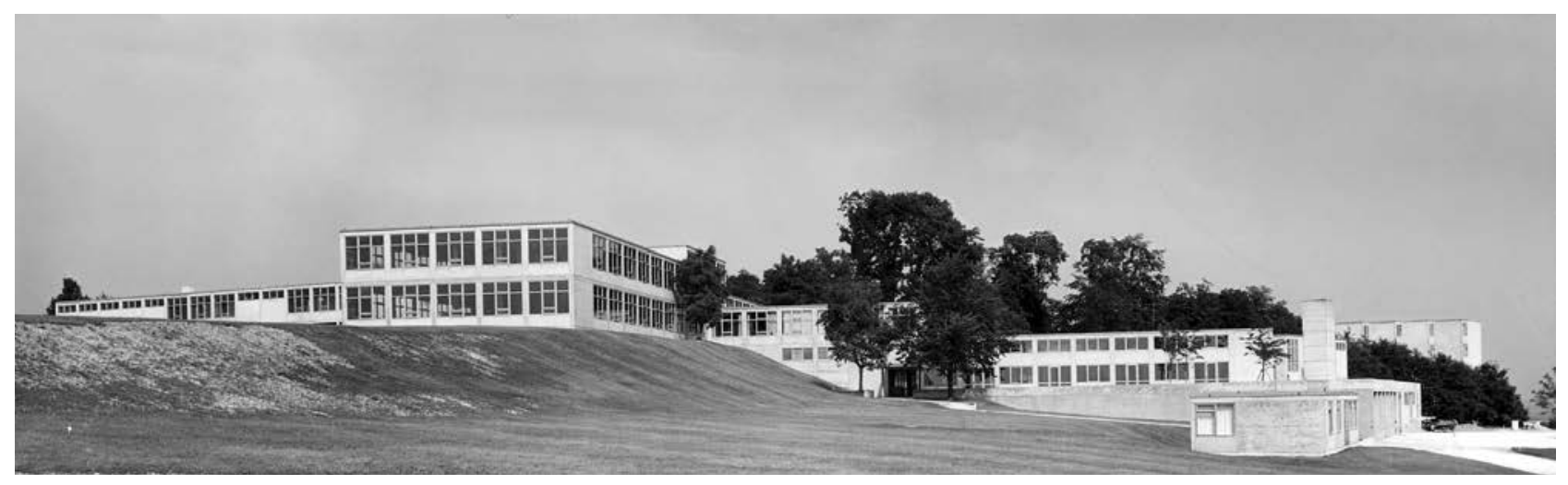

A Escola de U1m | Hochschule für Gestaltung. MU HfG Archiv.

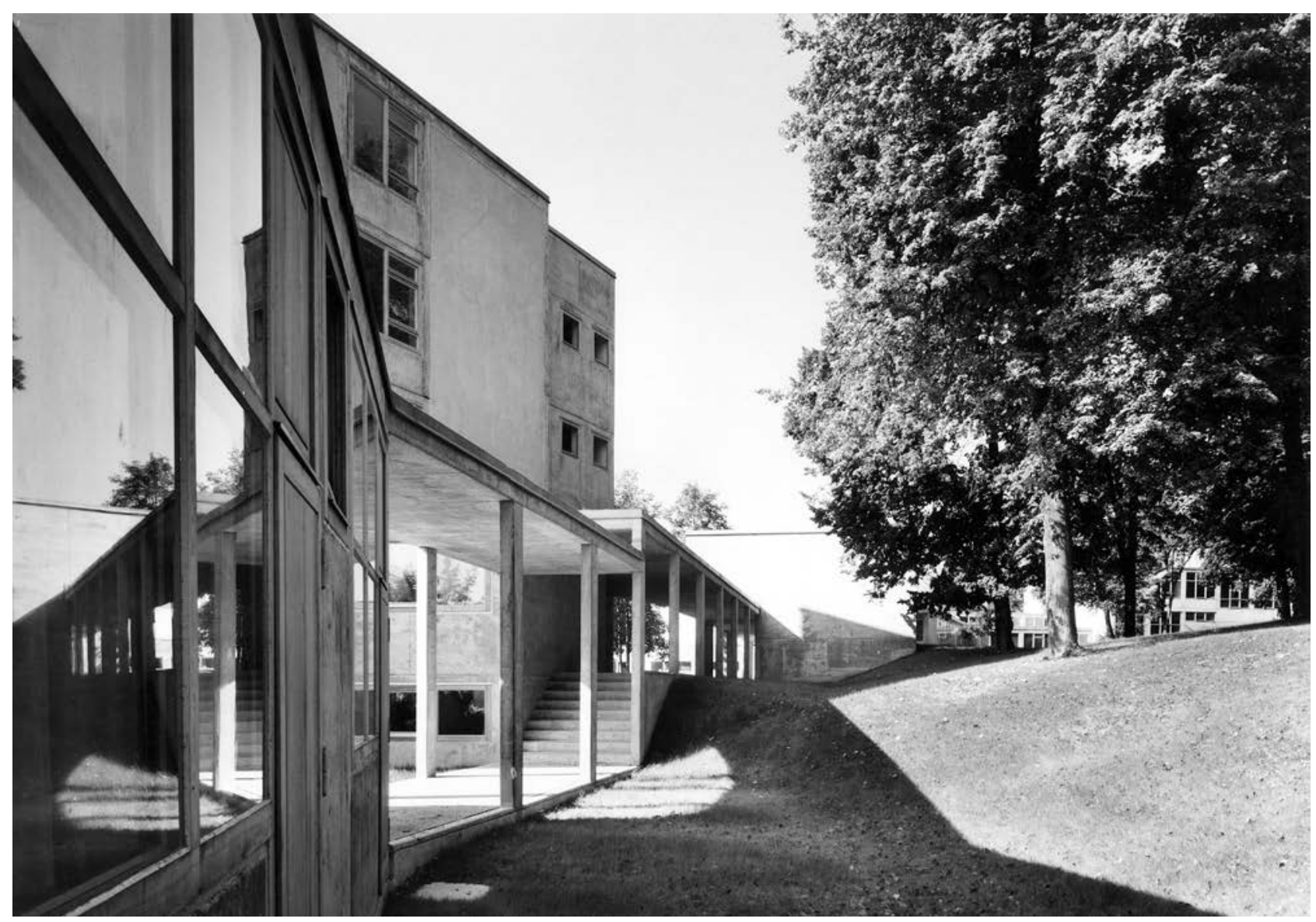






1.08.1956. Aniversário de Inge Aicher Scho11. Uma das várias fotos tiradas no terraço da HfG-Ulm. Sentados: 0tl Aicher, Inge Scholl, Max Bill, Konrad Wachsmann e Karl Heinz Bergmi1ler. Ao centro reclinados: Alexandre Wollner e Christoph Naske. MU HfG Archiv. 


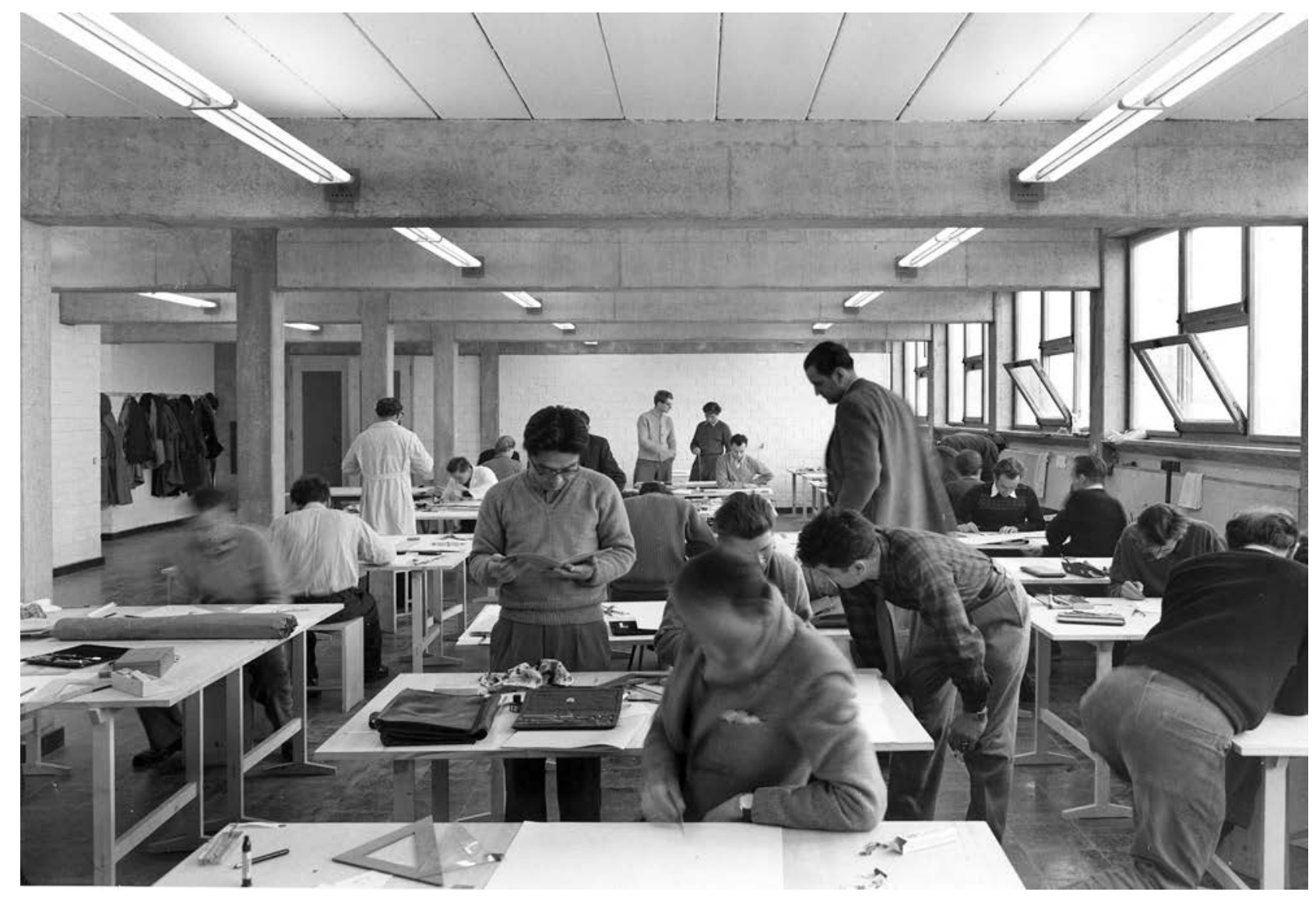

Ateliê e refeitório na HfG-U1m. Fotos U1rich Burandt, MU HfG Archiv.

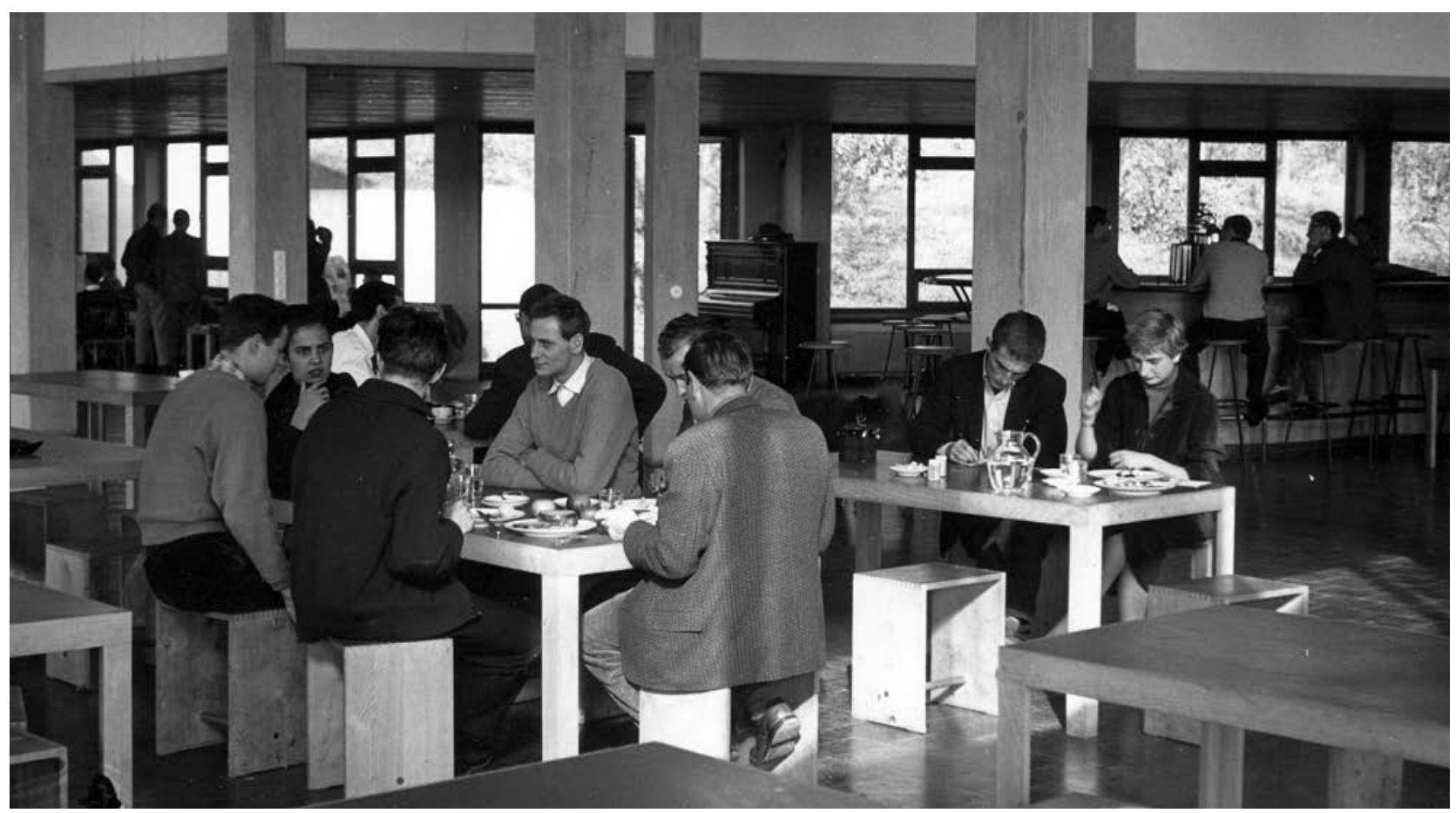


O trabalho consistia no desenvolvimento de um novo telefone de mesa, respeitando as normas estabelecidas pelo Deutsche Bundepost, que definiam os componentes internos do aparelho e outros critérios como o ângulo de $146^{\circ}$ entre fone e microfone no monofone e o sistema de discagem.

Diante das limitações estabelecidas foi um típico trabalho de redesenho. Mesmo assim, as funções básicas de uso deveriam ser submetidas a análises parciais e, posteriormente, testadas em modelos funcionais especialmente construídos.

Dentre os fatores passíveis de modificação ou estabelecidos a partir do projeto, consideraram-se os seguintes: o aparelho deveria ocupar o menor espaço possível na mesa; experiências ergonômicas indicaram que o monofone deveria ficar no sentido transversal, permitindo que o usuários, ao esticar o braço, pudesse pegar, levantar e desligar confortavelmente o aparelho, ou seja, sem fazer movimentos de rotação com a mão; o disco deveria ficar num ângulo de $40^{\circ}$, garantindo boa visibilidade e manipulação; a largura do aparelho resultaria do comprimento do monofone e a altura e a profundidade seriam determinadas pela posição do disco.

Todas essas considerações indicaram uma base de forma triangular. Atrás do aparelho foi prevista uma cavidade, com espaço para quatro dedos, possibilitando uma movimentação segura do aparelho com uma única mão. Todos os componentes técnicos cabiam na nova caixa que ocupava menos espaço que os aparelhos então existentes.
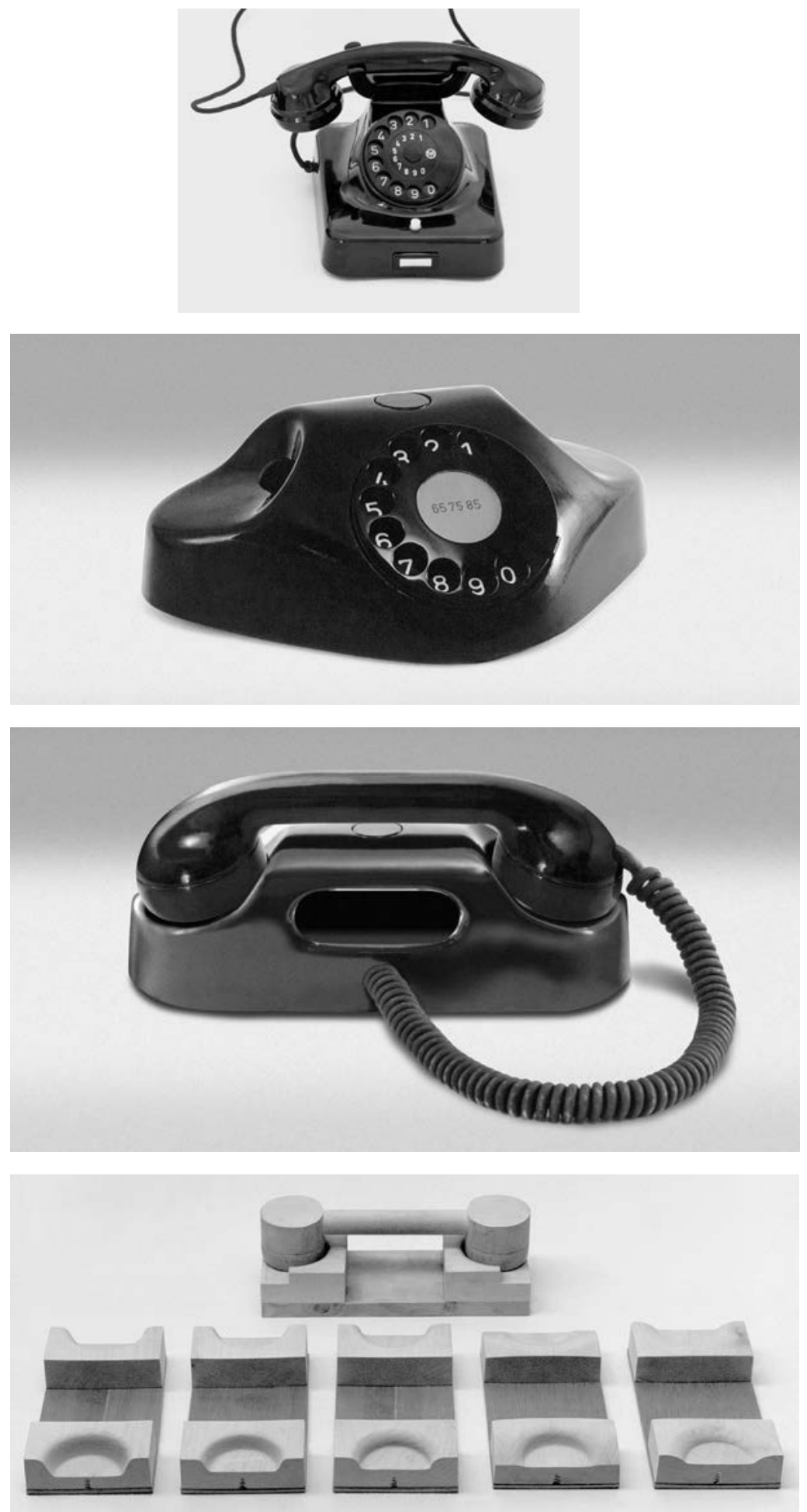
Telefone de mesa

Merk Telefonbau AG

HfG-Ulm. Ateliê Max Bill

Ulm, Alemanha, 1956.
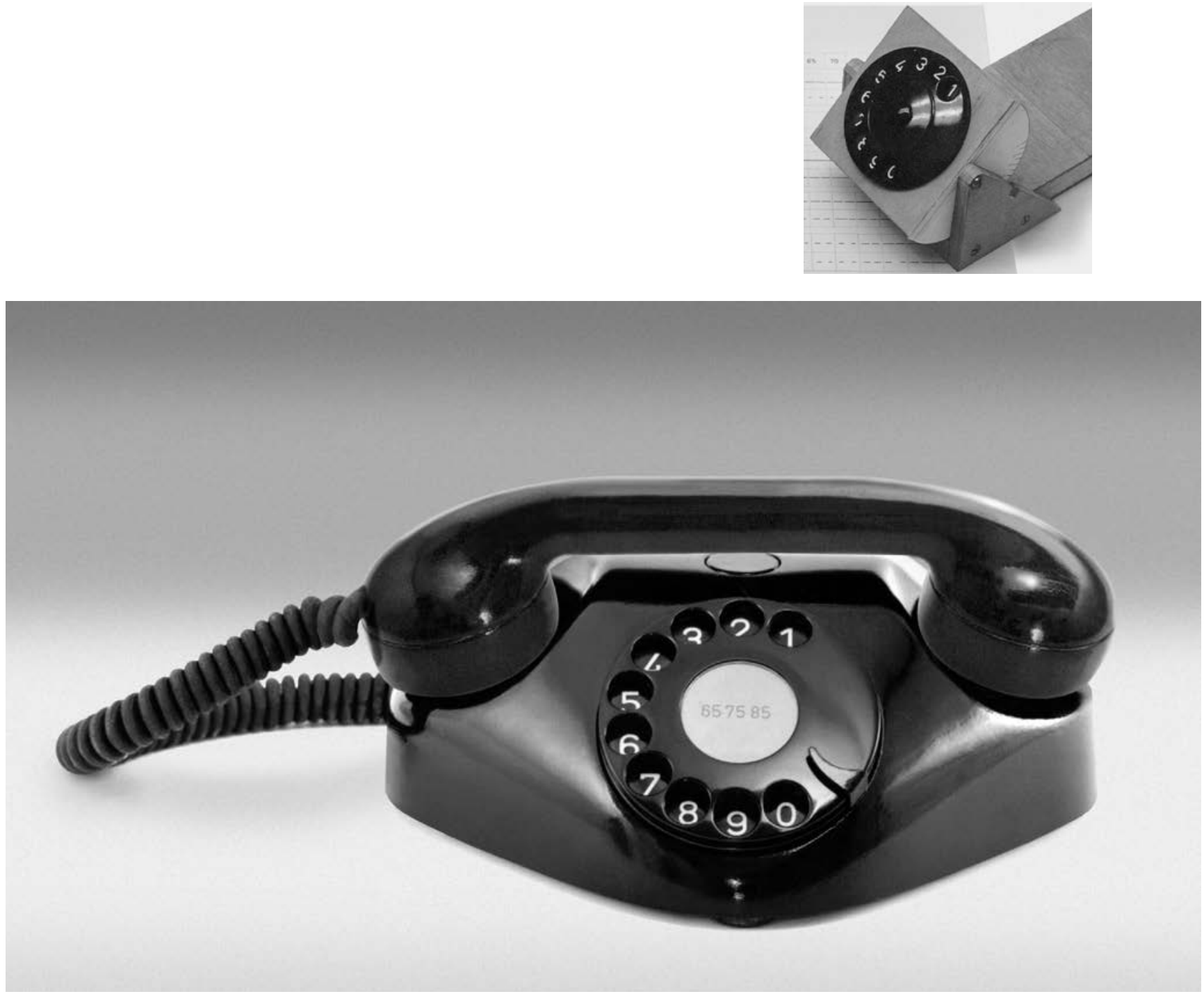


\section{Central telefônica de mesa}

Merk Telefonbau AG.

HfG-Ulm. Ateliê Max Bill

Ulm, Alemanha, 1956.

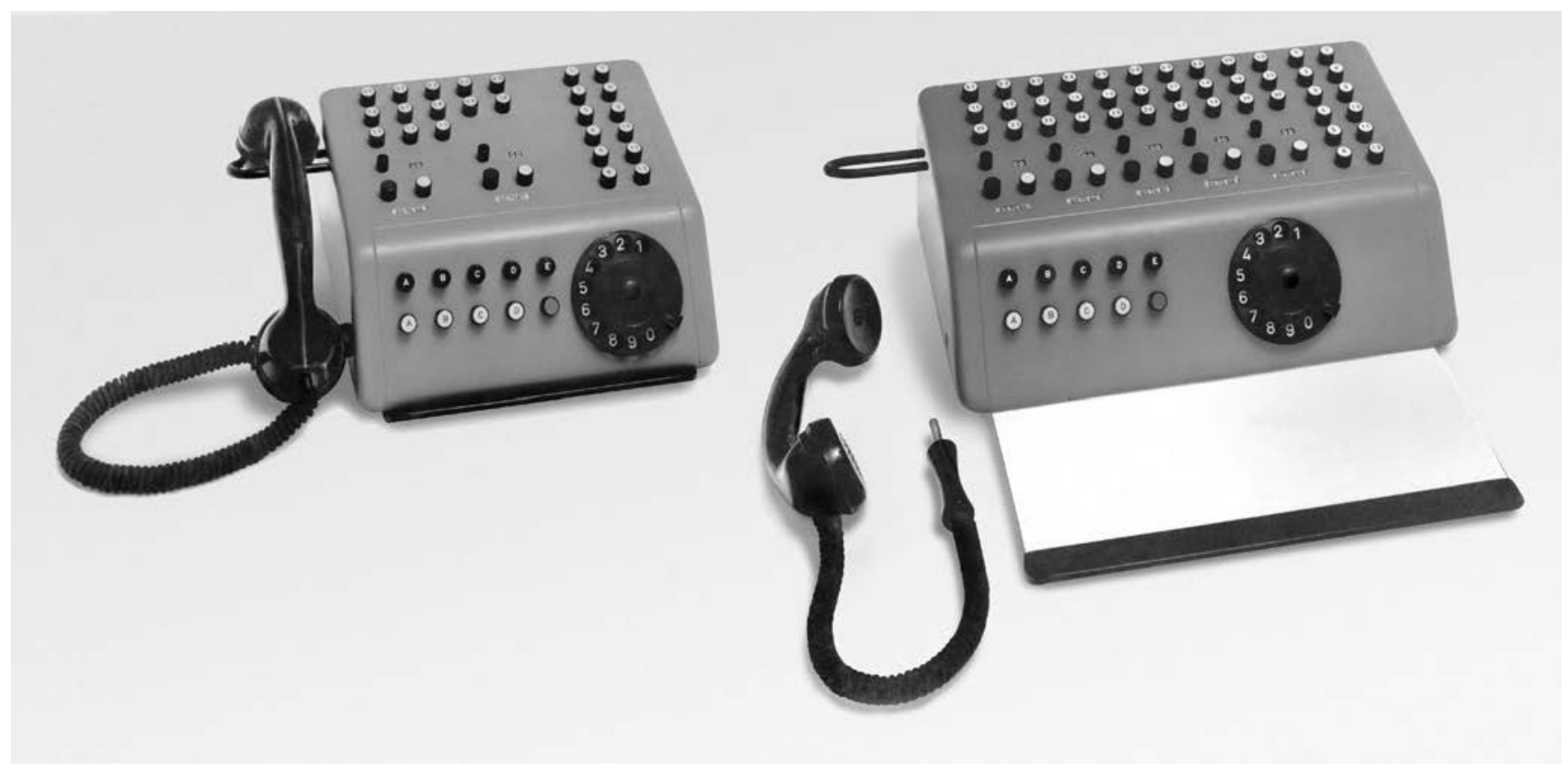

Passados cinquenta anos, muitos dos argumentos considerados estão superados pela evolução na área da telecomunicação. Surgiram novos componentes, novos aparelhos e novos conceitos de produtos na área. Desde a substituição dos discos por teclas, o surgimento de novos modelos de mesa, de telefones sem fio, até os celulares que atendem a qualquer capricho individual, essa evolução demonstra como seria necessário que o designer trabalhasse vinculado às pesquisas tecnológicas dos produtos que projeta. Demonstra ainda que limitações normativas podem gerar mais problemas que facilidades. Normas também são superadas pelas próprias tecnologias que imaginam regulamentar e são mal interpretadas, transformando-se em elementos de conservadorismo no desenvolvimento industrial. 


\section{Vendedor automático}

HfG-Ulm, Diplomarbeit

Trabalho prático de formatura

Ulm, Alemanha, 1958.

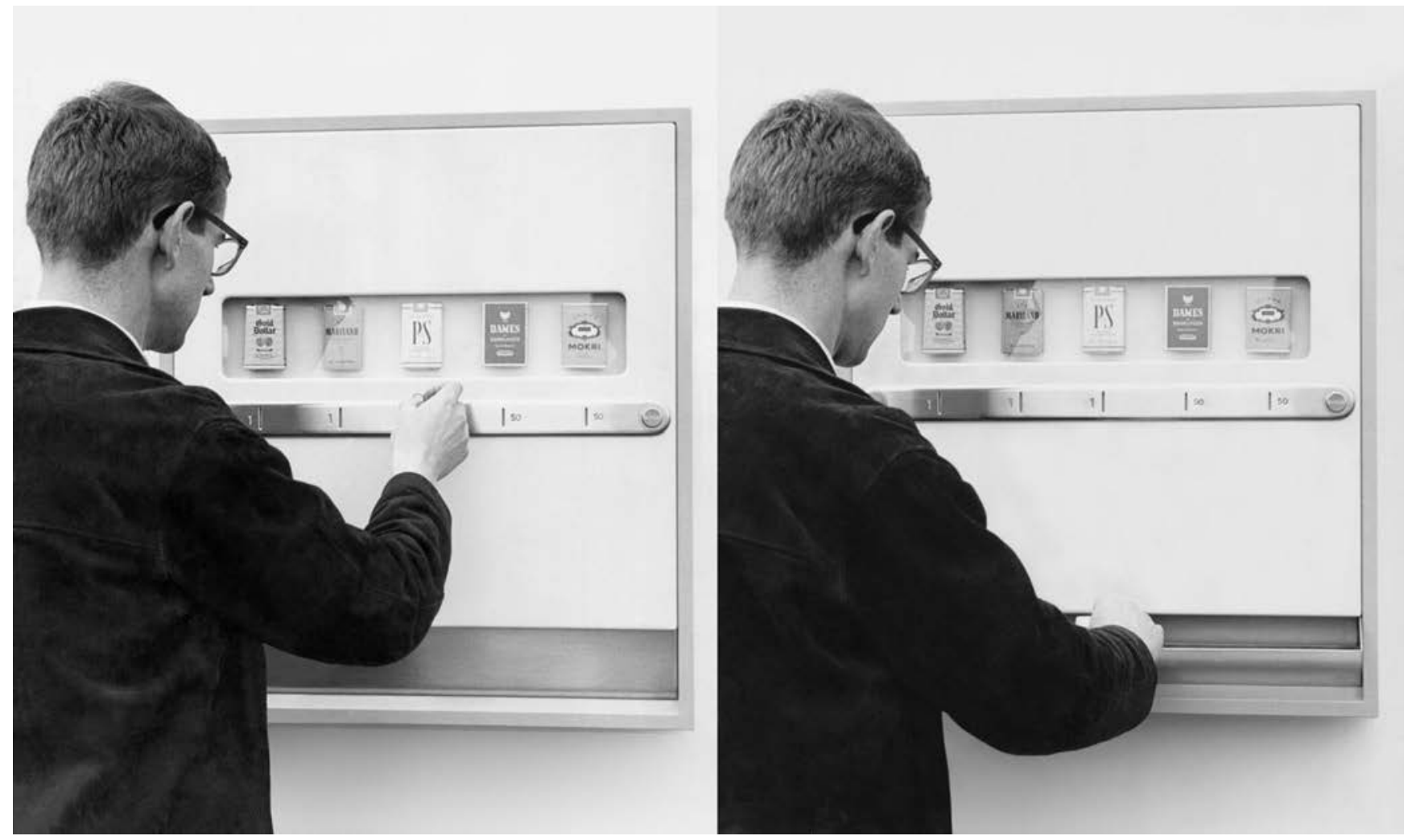

A HfG-Ulm exigia, para a obtenção do diploma, a apresentação de um projeto prático e um trabalho teórico. Minha proposta de um vendedor automático justificava-se pela expectativa de um grande desenvolvimento desse tipo de serviço na época, juntamente com o argumento de que esses produtos deveriam ser muito bem trabalhados para evitar que se transformassem em elementos de poluição visual.

A intenção era desenvolver o trabalho em uma empresa para obter o maior número possível de dados reais e realizar modelos e experiências concretas. Essa expectativa foi frustrada, pois os fabricantes de vendedores automáticos consideravam seu projeto uma responsabilidade exclusiva da engenharia. Os dados considerados foram obtidos mediante bibliografia especializada e pela observação, experiência e análise de uso dos vendedores automáticos existentes na cidade.

Como em todo trabalho acadêmico, esse projeto foi desenvolvido num processo em que a metodologia e os dados obtidos nas diversas fases de seu desenvolvimento foram igualmente importantes para o resultado final. 0 projeto foi posteriormente publicado em revistas e livros de design. A indústria de vendedores automáticos percebeu então que seu produto não era apenas engenharia. Recebi propostas de trabalho, mas nessa época já estava no Brasil e meus interesses estavam dirigidos para outros aspectos do design. 


\section{Die zerlegbare \\ Sitzgruppe \\ Modell SBM 680/380}

Design: Bergmiller - Moeckl

A poltrona foi industrializada pela firma Wilde und Spieht da Alemanha, a partir de 1959. 0 sistema construtivo foi patenteado e, no início da década de 1960, a poltrona foi incorporada à coleção de design do MoMA de New York e, depois, a diversas outras coleções de produtos de "good design". O desenvolvimento dessa poltrona significou para nós, antes de tudo, um exercício, um trabalho radical porém disciplinado, sem a necessidade de qualquer tipo de concessão, seja ao cliente, seja ao mercado.

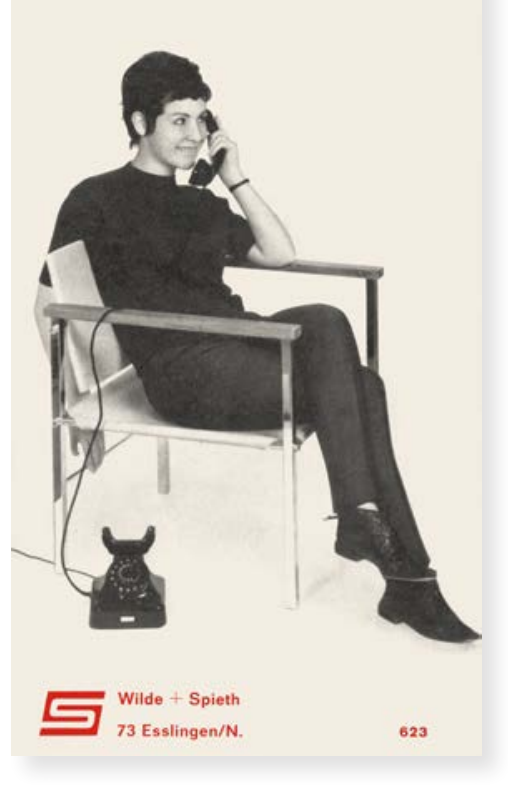

Consistia numa estrutura de madeira maciça, montada através de encaixes, com o assento, encosto e braços feitos em couro de sola tensionados sobre a estrutura. Mas, a "colonial chair" desmontada resultava em um conjunto de peças desajeitado. 0 objetivo de nossa cadeira era que, desmontada, ocupasse o mínimo de espaço, mantendo-se em ordem, e demonstrando, com isso, suas qualidades formais.

Foram usados materiais e tecnologias modernos, mas a proposta sempre foi manter o máximo de simplicidade em sua utilização. Quatro tubos quadrados verticais e quatro tubos redondos horizontais, unidos por parafusos e dois sarrafos de madeira como apoio para os braços, encaixados nos topos dos tubos verticais, formam o esqueleto básico. Assento e encosto em couro eram presos a essa estrutura. Desmontada, a parte estrutural resulta num volume retangular de $88 \times 44 \times 570 \mathrm{~mm}$, envolvido pelo couro utilizado no assento e no encosto.

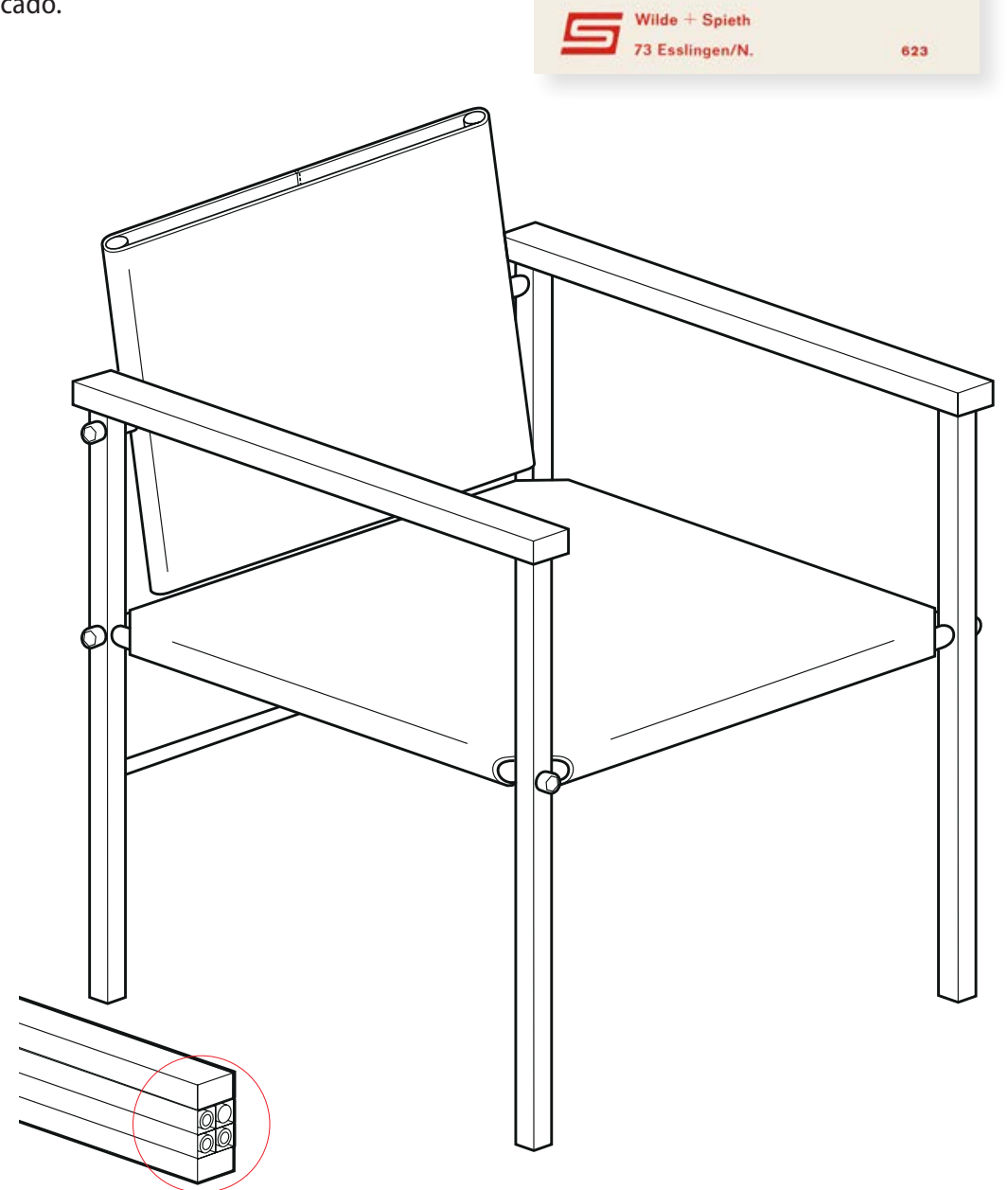


Poltrona desmontável

HfG-Ulm. Projeto extracurricular

com o colega Ernst Moeckl

Ulm, Alemanha, 1957.

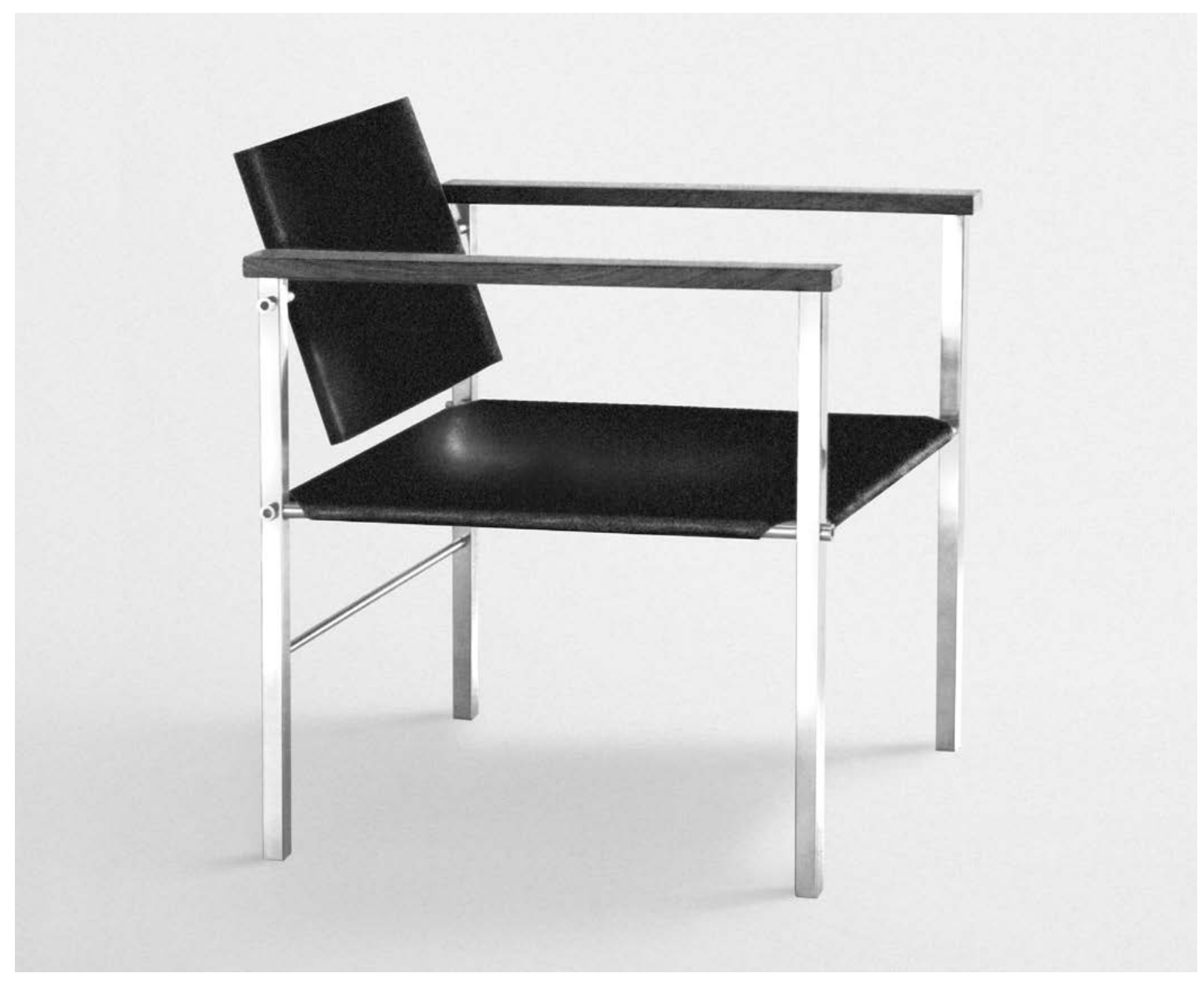




\section{Luminária de mesa}

HfG-Ulm. Ateliê Max Bill

Ulm, Alemanha, 1956.

Uma empresa de luminárias domésticas solicitou ao Ateliê Max Bill o projeto de uma luminária de mesa contemporânea, estilo para o qual se imaginava que deveriam convergir os critérios das pessoas mais esclarecidas e sofisticadas. Além das lâmpadas simples incandescentes, surgiam nessa época, no mercado de consumo, vários outros tipos, como as fluorescentes e as refletoras, que raramente eram utilizadas em ambientes domésticos.

O conceito inicial da nova luminária de mesa foi exatamente o desafio de empregar lâmpadas refletoras e a mais adequada para responder a isso foi a Comptalux 150W. A ideia era emitir luz indireta no teto e uma luz difusa em volta da luminária na mesa. Lâmpadas refletoras resultam em muito calor, e por isso a circulação constante de ar deveria ser observada. A concepção final resultou em dois "cilindros cúbicos", nos quais o diâmetro é igual à altura, abertos nos dois lados, um deles de metal cromado e o outro de acrílico fosco, unidos por um simples encaixe. 0 conjunto fica suspenso sobre a superfície da mesa, provocando uma circulação de ar permanente. 0 cilindro de acrílico serve como difusor e produz uma luz suave na mesa. 0 bocal da lâmpada refletora fica encaixado no tubo de metal cromado que é preso numa cruzeta de acrílico através de um sistema de baioneta.

O cliente era um fabricante tradicional de abajures de papel e de seda. Não entendeu a proposta e não conseguiu identificar o objeto como uma luminária de mesa contemporânea.

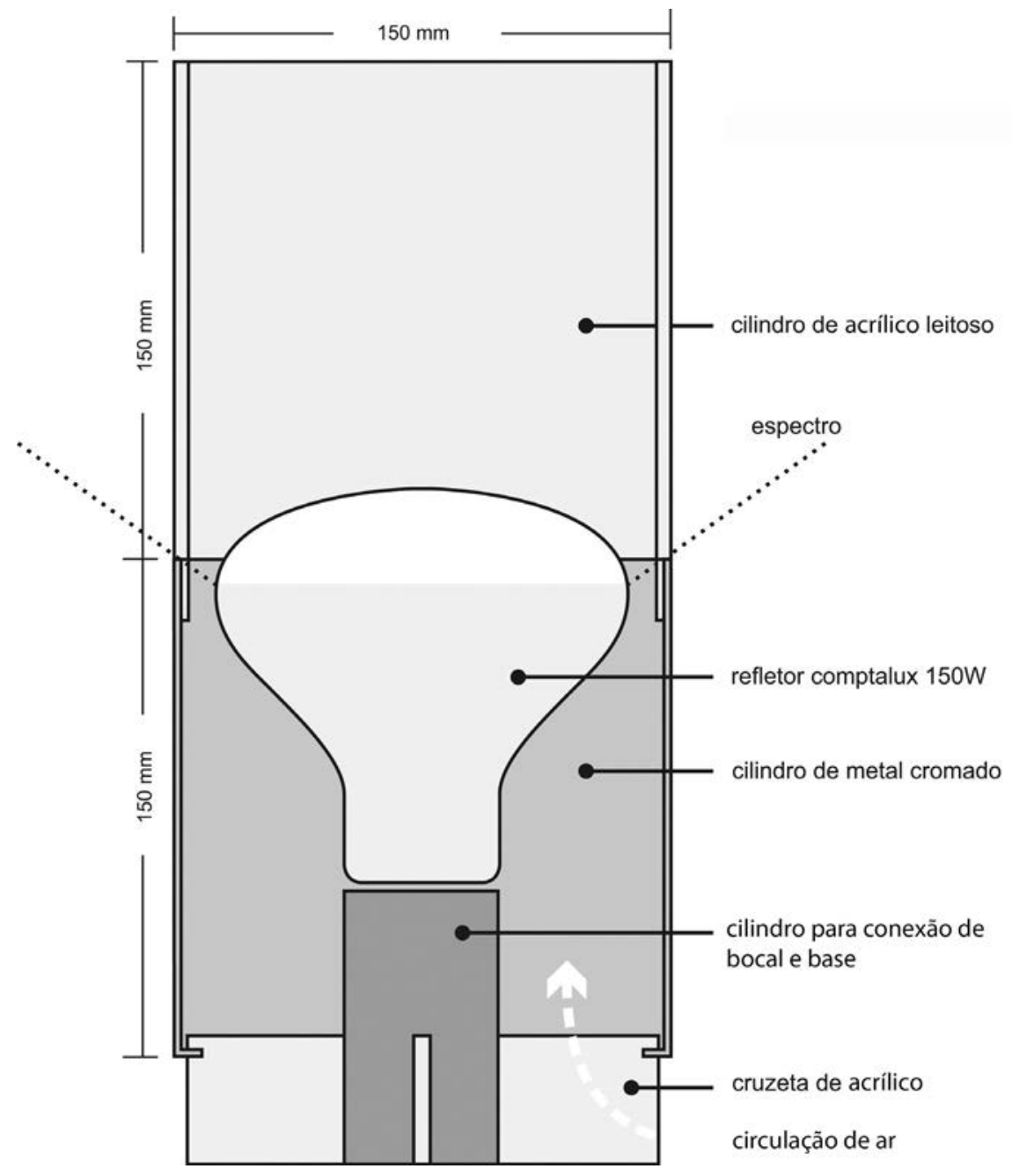




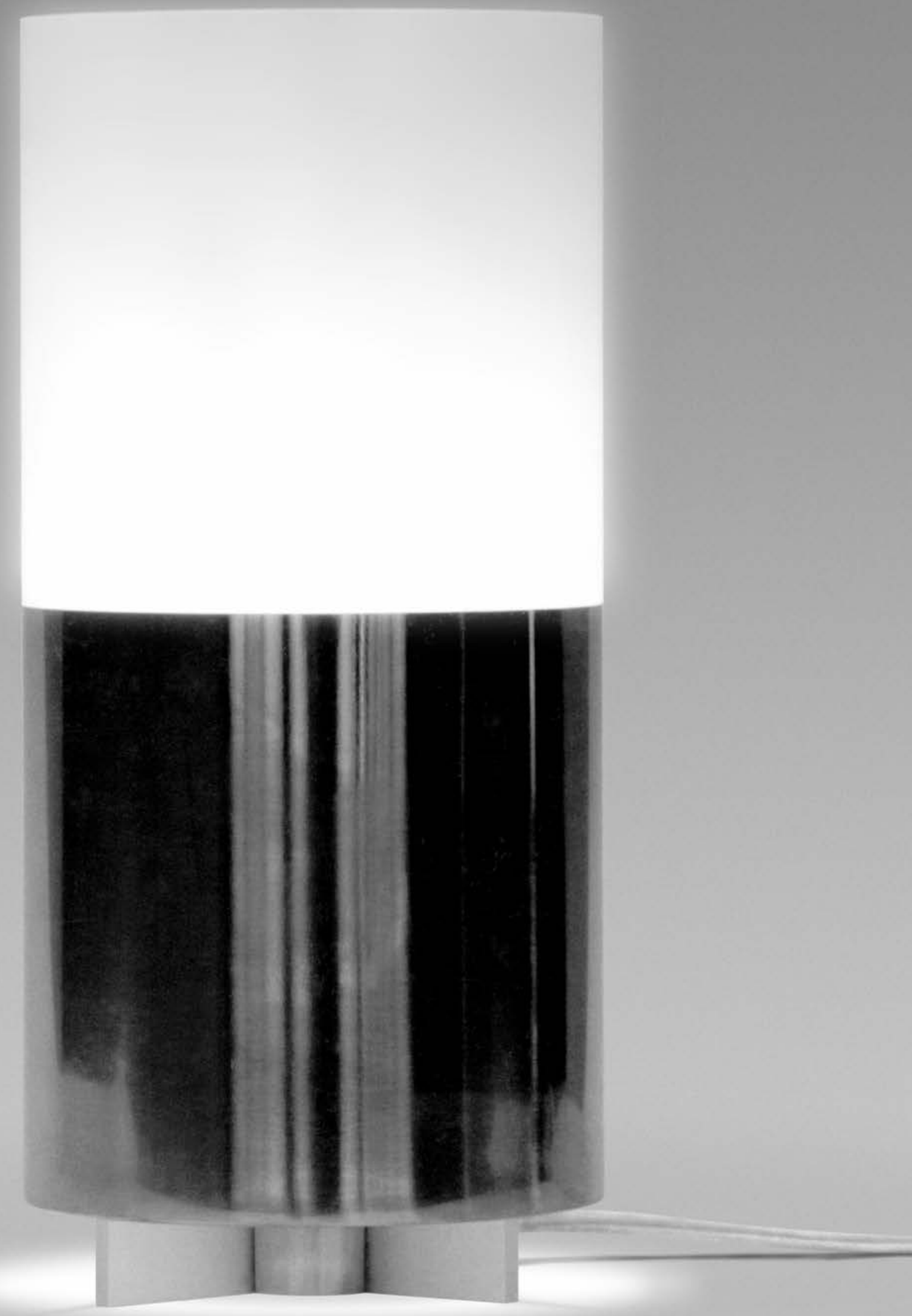




\section{notas | O DESIGN MODERNO}

1. Karl Popper (1902-1994). Áustria. Filósofo dos mais influentes do século XX estudou e criticou a ciência. Defensor da democracia liberal, foi adversário declarado de qualquer tipo de totalitarismo. Ele é conhecido pela sua defesa da falseabilidade como um critério da demarcação entre a ciência e a não ciência e pela sua defesa da sociedade aberta. Popper definiu sua filosofia como Racionalismo Crítico. Essa designação é um indício da sua rejeição do empirismo clássico e do observacionismo-indutivista da ciência, que disso resulta. Popper argumentou que a teoria científica será sempre conjetural e provisória. Não é possível confirmar a veracidade de uma teoria pela simples constatação de que os resultados de uma previsão efetuada com base naquela teoria se verificaram. Essa teoria deverá gozar apenas do estatuto de uma teoria não (ou ainda não) contrariada pelos fatos. O que a experiência e as observações do mundo real podem e devem tentar fazer é encontrar provas da falsidade daquela teoria. Esse processo de confronto da teoria com as observações poderá provar a falsidade [falsify] da teoria em análise. Nesse caso há que eliminar essa teoria que se provou falsa e procurar outra teoria para explicar o fenômeno em análise. No entanto, existem críticas à teoria de Popper em sua própria filosofia: ao afirmar que toda e qualquer teoria deve ser falseável, isso se aplica à própria teoria da falseabilidade e, portanto, a falseabilidade deve ser falseável em si mesma.

2. Hans Albert (1921). Alemanha. Filósofo. Com pesquisas focadas nas áreas das Ciências Sociais e do Estudo Geral dos Métodos, foi responsável por dar ao Racionalismo Crítico de Karl Popper uma reformulação concisa e de grande alcance. Para ele, nenhum campo das ciências humanas está isento de uma postura crítica. Hans Albert se opõe à teoria crítica da Escola de Frankfurt defendida por Adorno e Habermas e também foi um forte crítico da tradição hermenêutica vinda de Heidegger Seu mais conhecido livro foi o Tratado da razão crítica, 1968.

3. Christopher Alexander (1936). Áustria. Arquiteto, matemático e urbanista. Tornou-se conhecido por suas teorias sobre o design, interpretado em seu sentido estrito, ou seja, como elemento ordenador e de planejamento. Seu livro Notes on the Synthesis of Form é requisito de leitura para pesquisadores em ciência da computação desde a década de 1960, sendo recomendado por Marvin Minsky, fundador do Laboratório de Inteligência Artificial do Massachuseetts Institut of Technology MIT. A obra teve influência nas décadas de 1960 e 1970 nas linguagens de programação para design, programação modular, programações orientadas para o objeto, softwares de engenharia e metodologias de design.

4. John Christopher Jones (1927). País de Gales. Engenheiro. Em 1970, Christopher Jones publicou Design Methods, que por muitos anos foi considerada uma obra importante para o design. Para Jones, a ergonomia era o maior fundamento do design. Seus estudos ergonômicos muitas vezes não eram utilizados, o que o levou a questionar os métodos de trabalho dos designers. Sentia-se frustrado com o que considerava a superficialidade do design nessa época. Segundo ele, os métodos utilizados eram insuficientes para trabalhar as necessidades individuais de gru- pos sociais e ambientais. Careciam de propósito, de ordem e não consideravam a escala humana. A visão de Jones, por sua vez, carecia de senso crítico. Não demonstrando talento para soluções formais, procurou deslocar o foco do design para trabalhos de sistematização com critérios autoritários e imperativos. Posteriormente, Jones reformulou muitos de seus princípios, aceitando que o mundo e, em menor escala, o design, não eram feitos nem de certezas e menos ainda de questões restritas ao certo e ao errado. Essas reflexões estão expressas em Diseñar el diseño, editado pela Gustavo Gili, em 1985.

5. Max Bense (1910-1990). Nasceu na França e tinha nacionalidade alemã. Matemático, físico e filósofo. Em 1925, publicou seus primeiros textos literários. Desde 1949, foi professor de filosofia da técnica, teoria científica e lógica matemática na Universidade Técnica de Stuttgart, onde permaneceu até 1976. Já no final da década de 1950 apareceu como personalidade central da Escola de Stuttgart, pelas suas suas formulações preliminares sobre uma estética racional. Influenciado pela cibernética e pelos computadores aplicados à arte, Bense dedicou-se à criação de uma teoria da informação para a estética. Criou o termo "estética informacional" e tentou desenvolver o discurso científico básico para uma estética quantitativa. Esse foi seu tema central em toda a sua obra: Aesthetic Information, 1957; Mathematics and Beauty, 1960; Aesthetica: an Introduction to New Aesthetics, 1965; An Introduction to Information Theoretical Aesthetics, 1969; The Representation and Gounding of Realities: the Sum of Semiotic Perspectives, 1986. Max Bense ligou-se aos movimentos concretos de arte e exerceu influência no Brasil, junto com os concretos e neoconcretos. Suas teses foram levadas à Escola Superior de Desenho Industrial do Rio de Janeiro ESDI, onde desenvolveu cursos especiais, em 1965. No entanto, não se pode dizer que suas ideias e teses tenham sido assimiladas no ensino da Escola. Mas, para correntes de pensamento lógico e neopositivistas, Max Bense foi uma importante referência. $O$ texto de seu curso durante anos foi utilizado nos debates internos da ESDI relativos a problemas de identidade e expressão nacional.

\section{BENZE, Max. Pequena estética São Paulo: Perspectiva, 1975.}

7. Konrad Fiedler (1841-1891). Alemanha. Teórico e crítico de arte. Procurou estabelecer em sua obra a independência da criação artística em relação à natureza - "A obra de arte não tem ideias, ela é uma ideia."

8. Jürgen Habermas (1929). Alemanha. Filósofo e sociólogo. É um dos grandes nomes da Teoria Crítica, originada na Escola de Frankfurt. De 1956 a 1959, foi assistente de Theodor Adorno no Instituto de Pesquisa Social de Frankfurt. Considerado como o continuador das discussões da Escola de Frankfurt, Habermas procurou superar o pessimismo de seus fundadores quanto às possibilidades de realização do projeto moderno, tal como formulado pelos iluministas. Profundamente marcados pelo desastre da Segunda Guerra Mundial, Adorno e Horkheimer consideravam que havia um vínculo primordial entre conhecimento racional e dominação, o que teria determinado a falência dos ideais modernos de emancipação social. Para recolocar o potencial emancipatório da razão, Habermas adota o paradigma comunicacional. Seu ponto de partida é a "ética comunicativa" de Karl Otto Apel, além do conceito de "razão objetiva" de Ador- 
no e do Idealismo alemão - particularmente na ideia hegeliana de reconhecimento intersubjetivo. Assim, Habermas concebe a razão comunicativa - e a ação comunicativa, ou seja, a comunicação livre, racional e crítica - como alternativa à razão instrumental e superação da razão iluminista, limitada pela lógica instrumental, que encobre a dominação.

9. Escola de Frankfurt é o nome dado a um grupo de filósofos e cientistas sociais de tendências marxistas que se destacaram no final da década de 1920. A Escola de Frankfurt se associa diretamente à chamada Teoria Crítica da Sociedade. A ela se deve a criação de conceitos como "indústria cultural" e "cultura de massa". Entre seus principais participantes estavam Theodor Adorno, Max Horkheimer, Walter Benjamin, Herbert Marcuse, Leo Löwenthal, Franz Neumann, Friedrich Pollock, Erich Fromm, Oskar Negt e Axel Honneth. O grupo emergiu no Instituto para Pesquisa Social de Frankfurt [Institut für Sozialforschung] da Universidade de Frankfurt-am-Main, na Alemanha. O Instituto tinha sido fundado com o apoio financeiro do mecenas judeu Felix Weil em 1923. Em 1931, Max Horkheimer tornou-se seu diretor. Com a chegada de Hitler ao poder, os membros do Instituto, na sua maioria judeus, migraram para Genebra, depois para Paris e, posteriormente, para a Universidade de Columbia, em Nova York.

10. Aloísio Magalhães (1927-1982). Brasil. Designer gráfico e artista plástico, formado em Direito. Começou sua carreira com pinturas que transitavam de paisagens à busca de elementos formais. É considerado um dos pioneiros na introdução do design moderno no Brasil, tendo participado da fundação da Escola Superior de Desenho Industrial ESDI. Entre seus principais projetos estão a identidade visual da Petrobras, o símbolo para o IV Centenário do Rio de Janeiro, a criação da primeira marca da TV Globo e o projeto gráfico das notas no Cruzeiro Novo (moeda adotada no Brasil a partir de 1966). Foi membro fundador do Gráfico Amador, uma gráfica e editora que começou em uma garagem de Recife e se destacou pela sua produção gráfica muito avançada para época, diferente do que se fazia até então. A sociedade primava pela excelência visual e pela qualidade dos textos.

11. Mário de Andrade (1893-1945). Brasil. Escritor, fotógrafo e pesquisador. Um dos principais nomes do movimento modernista brasileiro, Mário de Andrade participou da Semana de Arte Moderna de 1922. Integrava, junto com Tarsila do Amaral, Anita Malfatti, Oswald de Andrade e Menotti del Picchia o Grupo dos Cinco, principal responsável pelo referencial artístico e ideológico da Semana de 22. Era um estudioso da cultura brasileira e foi o fundador do Departamento de Cultura de São Paulo. Sua atuação nos campos da poesia, romance, crônica, jornalismo, música, folclore e crítica guiava-se sempre pela busca de aspectos definidores da identidade nacional e pela valorização das manifestações artísticas e culturais do Brasil. Suas mais conhecidas obras são Pauliceia desvairada, 1922 e Macunaíma, 1928. Em 1942, proferiu, na Casa do Estudante, no Rio de Janeiro, a palestra "O Movimento Modernista", na qual relativiza seu passado, e fala sobre sua geração.

12. ANDRADE, Mário de. Ideologia da cultura brasileira. São Paulo: Ática, 1977.
13. Maria Montessori (1870-1952). Itália. Pedagoga. Desde menina manifestou interesse pelas matérias científicas, principalmente matemática e biologia, entrando em conflito com seus pais, que desejavam que a filha seguisse a carreira de professora. Indo contra essas expectativas, ela se inscreveu na Faculdade de Medicina da Universidade de Roma, escolha que a levou a ser, em 1896, a primeira mulher a se formar em medicina na Itália. Após sua formatura, iniciou um trabalho com crianças excepcionais na clínica da universidade. Em 1898, Montessori defendeu a tese de que essas crianças precisavam muito mais de um bom método pedagógico do que da medicina, assegurando que as esperanças de desenvolvimento estavam no mestre, não no clínico. Para isso, era necessário que se criasse um ambiente favorável ao aluno. Nas viagens que fez a Paris e Londres, notou que as escolas especializadas superavam as tradicionais. Para ela, só havia uma explicação: essas escolas estavam mal organizadas e seus métodos eram péssimos. Lançou-se à gigantesca tarefa de melhorar o ensino infantil. Observou também crianças que ficavam nas ruas e criou um espaço educacional para elas. O método de aprendizagem Montessori é caracterizado por uma ênfase na independência, liberdade com limites e respeito pelo desenvolvimento natural das habilidades físicas, sociais e psicológicas da criança.

14. Georg Kerchensteiner (1854-1932). Alemanha. Pedagogo. Exerceu variadas atividades na área: professor e diretor de escolas públicas, político e professor universitário. Suas principais referências teóricas foram a filosofia educativa de Johann Heinrich Pestalozzi, a ampla visão sociológica da educação de John Dewey e a perspectiva cultural-histórica de Eduard Spranger. Kerchensteiner foi uma importante referência para as chamadas escolas do trabalho e definiu sua pedagogia, ressaltando o valor da inteligência prática sobre um "intelectualismo inútil", voltada especialmente para o trabalho e para a formação profissional. A pedagogia deveria permitir que um saber se tornasse competência, único sinal de uma aquisição real desse saber. Recusou sempre um sentido de oposição entre formação geral e formação profissional. Foi o grande reformador do ensino alemão no período que se seguiu à unificação da Alemanha. Suas teses adequaram-se, ou foram adequadas, aos objetivos do projeto de transformação da recém-unificada Alemanha em um Estado Empresa e, posteriormente um Estado Nação.

15. Domenico de Masi (1939). Itália. Sociólogo. Defensor de uma nova sociologia do trabalho baseada na criatividade e em seu famoso conceito de "ócio criativo". Para ele, as pessoas podem se tornar profissionais melhores caso tenham mais tempo de lazer. Ele questiona as relações tradicionais de trabalho e argumenta que a criatividade é o maior capital dos países ricos, que vivem literalmente de ter boas ideias. O seu trabalho inclui temas bastante variados como mercado de trabalho, estrutura organizacional, estratégias empresariais, motivação individual, grupos criativos, ética e estética, entre outros. Em sua obra Criatividade e grupos criativos, Domenico de Masi analisa a experiência criativa da humanidade, refazendo o percurso desde a pré-história até a atual sociedade pós-industrial para construir a tese de que ao contrário do que se pensa, a 
maior parte das importantes criações humanas não é fruto de um grande gênio isolado e, sim, de grupos e coletividades.

16. O Deutscher Werkbund foi fundado em 1907, congregando arquitetos, artesãos e artistas, em uma espécie de órgão diretivo das atividades relacionadas à criação formal utilitária. Foi inspirado, em sua essência, pela ação do arquiteto Hermann Muthesius, que já havia visitado o Japão e fora enviado a Londres, em 1896, como adido cultural da embaixada alemã com o objetivo específico de estudar a arquitetura e os movimentos relacionados às artes aplicadas na Inglaterra. Mas o Deutscher Werkbund não nasceu apenas das atividades de Muthesius e nem foi um projeto surgido ao acaso. Havia na Alemanha antecedentes importantes para a formulação desse projeto no final do século XIX e sua fundação no início do século XX. Desde 1870, algumas iniciativas no campo das artes aplicadas visavam colocá-las num mesmo patamar de valor que as chamadas artes maiores, ressaltando sua utilidade diante da nascente industrialização e da possibilidade de potencializar os produtos alemães considerando a competitividade de produtos fabricados no exterior. O princípio básico para essa valorização foi apoiado na educação, instrução e atualização, tanto dos operários como do público em geral, sobre as características e qualidades possíveis a partir dos novos processos de fabricação. Para tanto foi organizado um sistema de informação que permitisse uma visualização direta e clara do que seria esse novo padrão. Escolas de arte vinculadas a essa nova ideologia, coligadas a uma rede de museus de objetos industriais e artísticos de vários tipos e procedências foram criadas. Escolas já existentes receberam incentivos para modificar seus programas de ensino e aproximarem-se de uma proposta geral, que adotava o critério de individualizar um produto (na escola) confrontando-o com outros (no museu), o que daria motivação à instituição tipicamente tardo-oitocentista que foi o museu artístico-industrial. Essa ordenação geral ficava a cargo do Museu Imperial de Artes Decorativas de Berlim, que fornecia apoio técnico e pessoal às escolas regionais e a vários museus, além das sociedades artísticas e industriais. Entre estas últimas instituições, que representavam a parte mais prática e viva de todo o sistema, incluíam-se a Deutscher Kunstgewerbe Verein de Berlim, com 1.263 sócios e a Bayerischer Kunstgewerbevereib de Munique, com 1.713 sócios. No início do século $\mathrm{XX}$, o número dessas associações chegou a 178, com 145.000 participantes.

17. A Wiener Werkstätte foi fundada em 1903 por Joseph Hoffmann, pelo pintor Koloman Moser e pelo banqueiro Fritz Waerndorfer. Apresentava-se formalmente eclética, com influências do Arts and Crafts, do Liberty inglês, da obra de Charles Rennie Mackintosh, do Art Nouveau, Jugendstil e Sezession vienense. A Wiener Werkstätte operou uma redução dessas influências e reelaborou-as num neoclassicismo muito particular, sua grande contribuição para o surgimento de um protorracionalismo do qual descendem o Art Déco, o estilo Novecento e os trabalhos de alguns americanos das décadas de 1930 e 1940. Como era costume na época, a Wienner Werkstätte também se apresentou através de um manifesto. No entanto, ao contrário da habitual declaração de princípios sociais, após justificar todas as suas opções formais, em uma última frase, o espírito da empresa é bastante claro: "Usaremos todas as nossas forças para atendermos [o gosto da burguesia], mas só poderemos ir adiante com a ajuda de todos os nossos amigos. Não podemos nos permitir a insegurança das fantasias. Temos os pés bem plantados no chão e esperamos suas encomendas." A firma abriu filiais em diversas cidades do mundo, Zurique, Marienbad, Breslau, Lucerna, Trieste, Berlim, e Nova York, incorporou o trabalho de vários outros artistas, criou um gosto burguês para os burgueses, numa ocasião em que parecia, de certa forma, ser uma necessidade afirmar-se solidário ao proletariado. Foi realmente um mérito extraordinário o fato de os artistas e designers da Werkstätte terem conseguido elevar o nível do gosto dessa burguesia enriquecida que consumiu seus produtos em todas as grandes capitais do mundo. A firma encerrou suas atividades em 1932 após apresentar problemas financeiros que não se deviam à não aceitação de seus produtos. A produção abrangia desde cartões postais, joias, vestuário e outros produtos pessoais de uso pessoal, até mobiliário, louças, vidraria, talheres etc.

18. Charles Jencks (1939). Estados Unidos. Teórico de arquitetura, paisagista e designer. Ficou conhecido por seus livros sobre história e crítica do Modernismo e Pós-Modernismo. Estudou literatura em Harvard, fez mestrado em arquitetura na mesma universidade e é doutor em história da arquitetura pelo University College em Londres. É lembrado por ter propagado o uso do termo "pós-moderno" em relação à arquitetura a partir do seu livro A Linguagem da arquitetura pós-moderna, 1977. Jencks ganhou destaque como paisagista na Inglaterra por seus trabalhos serem inspirados na genética e na teoria do caos. Atua também como designer de mobiliário e escultor.

19. A Fundação Irmãos Scholl foi uma das incentivadoras e participou ativamente do projeto de criação da Escola de Ulm. Ela foi criada em 1950, por Inge Scholl, em memória de seus irmãos Sophie e Hans Scholl, membros do grupo de resistência ao nazismo "Rosa Branca". Ambos, inicialmente, foram seduzidos pela filosofia do Nacional Socialismo, chegando a participar da Juventude Hitlerista. Ao ingressar na faculdade, Hans formou junto com amigos um grupo para apreciar e discutir arte, filosofia, teologia, música e literatura. Depois que seu pai foi preso, por externar críticas a Hitler, e do namorado de Sophie relatar os horrores cometidos no front, eles mudaram radicalmente suas posições. Hans Scholl, Willi Graf e Christoph Probst fundaram a Rosa Branca, logo depois Sophie Scholl se juntou a eles. Ao todo foram redigidos e distribuídos seis panfletos antinazistas. Os quatro primeiros tinham um fundo mais teológico e filosófico, já os dois últimos incitavam a população para a ação. Em 1943, quase um ano depois da fundação do grupo, os irmãos Scholl foram presos, julgados e condenados à morte na guilhotina, acusados de alta traição.

20. Otl Aicher (1922-1991). Alemanha. Programador visual, tipógrafo. Um dos fundadores da HfG-Ulm. Professor desde 1951 e membro da direção colegiada de 1956 a 1959. Estudou escultura em 1946 na Academia de Munique. Em 1947 teve um escritório gráfico em Ulm e depois em Munique e, a partir de 1972, em Rotis. Foi professor visitante na Universidade de Yale e, na década de 1950, desenvolveu cursos no Museu de Arte Moderna do Rio de Janeiro. Entre seus principais projetos: a imagem empresarial da Lufthansa, da Braun, ZDF, ERCO-Luci, Dresdner Bank, Westdeutsche Landesbank; a identidade visual e a sinalização do aeroporto de Frankfurt, identidade e programação visual para os Jogos 
Olímpicos de Munique [1972], quando desenvolveu um extraordinário sistema de pictogramas. Em 1984, fundou o Instituto Rotis para Estudos Analógicos. Publicou numerosos livros, entre eles: Zeichensysteme (Munique: Alexander Koch, 1980), com Martin Krampen; Kritik am Auto (Munique: Callwey, 1984); Die Küche zum Kochen (Munique: Callwey, 1982); Greifen und Griffe (Colônia, 1987), com Obert Kuhn.

21. Fritz Winter (1905-1976). Alemanha. Pintor. Estudou por três anos na Bauhaus. Lecionou na Pädagogische Akademie, em Halle. Em 1939, foi enviado para o front oriental, sendo capturado pelos russos quase no final da guerra e só liberado em 1949. Assim que voltou foi cofundador do grupo Zen 49, que tinha como membros Willi Baumeister, Rolf Cavael, Gerhard Fietz, Rupprecht Geiger, Willy Hempel e Brigitte Meier-Denninghoff. Foi considerado um dos mais famosos pintores alemães do pós-guerra.

22. Helene Nonnée Schmidt (1891-1976). Alemanha. Estudou em Berlim e foi professora de desenho. Ensinou em escolas secundárias, de 1919 até 1924. Em 1923, após uma visita a uma exposição da Bauhaus, decidiu se inscrever na Escola. Foi dispensada do curso básico e começou a trabalhar no ateliê de tecelagem. Em 1925, ela se casou com um colega da Bauhaus, Joost Schmidt. Depois da morte do marido, em 1948, trabalhou como jornalista e cinco anos depois foi convidada por Max Bill a lecionar teoria da cor na HfG-Ulm, onde permaneceu até 1957. Depois decidiu se dedicar a elaborar um livro sobre a obra de Joos Schmidt, publicado em 1969, na Suíça, como parte de uma coleção intitulada Dokumente visueller Gestaltung. Juntamente com Heinz Loew, publicou em 1984 o livro Joos Schmidt - Lehre und Arbeit am Bauhaus 1919-1932. Nonnée Schmidt escreveu ainda o ensaio "Woman's Place at the Bauhaus", 1976.

23. Carl Zuckmayer (1896-1977). Alemanha. Dramaturgo. Logo depois da Primeira Guerra Mundial, durante a qual serviu o exército alemão, iniciou os estudos na Universidade de Frankfurt, primeiro em humanidades, depois em biologia. Seus primeiros textos, tanto em literatura quanto no teatro foram um fracasso. Seu primeiro sucesso de público aconteceu apenas, em 1925, com a comédia The Merry Vineyard, que ganhou o Prêmio Kleist. Suas peças foram proibidas com a ascensão do nazismo ao poder, e ele chegou a ser expatriado pelo governo. Ele e sua família fugiram para os Estados Unidos, onde Zuckmayer trabalhou pela primeira vez como roteirista, em Hollywood. Ficou conhecido pelos numerosos prêmios literários que recebeu. Sua última peça, Ring of Salzburg, estreou em Zurique, em 1975.

24. Werner Karl Heisenberg (1901-1976). Alemanha. Físico e teórico. Recebeu o Prêmio Nobel de Física em 1932 pela criação da mecânica quântica, cuja aplicação possibilitou, entre outras, a descoberta das formas alotrópicas do hidrogênio. As ideias do físico romperam com grande parte dos princípios da física newtoniana, sendo por esse motivo rejeitadas por alguns cientistas, como Einstein, por exemplo. O "princípio de Heisenberg" abriu um novo campo tanto para a física como para a teoria do conhecimento.

25. Konrad Zacharias Lorenz (1903-1989). Áustria. Zoólogo. Foi fundador de uma nova área de estudos conhecida como Etologia, que se baseia no estudo comparativo do comportamento humano e animal. Demonstrou desde cedo grande interesse pe- los animais, observando seus comportamentos no minizoológico que tinha em casa, anotando metodicamente em um diário o comportamento de suas aves. Graduou-se em medicina e fez doutorado em zoologia. Serviu o exército alemão como médico e foi capturado pelos russos. Provavelmente, devido a essa sua experiência na guerra, desenvolveu um estudo sobre a agressividade humana, exposto no livro Sobre a agressão, 1963. Pelas suas descobertas recebeu o Prêmio Nobel de Fisiologia, em 1973.

26. Carl Orff (1895-1982). Alemanha. Compositor. Estudou na Academia de Música de Munique até 1914. Serviu às forças armadas durante a Primeira Guerra Mundial. Em 1925, foi cofundador da Guenther School, um centro de educação musical para crianças e leigos. Nessa escola trabalhou com iniciantes em música até o final de sua vida e a partir dessa experiência desenvolveu suas teorias de educação musical. O Método Orff, como ficou conhecido, baseava-se na percussão e no canto. Sua cantata Carmina Burana tornou-se muito popular.

27. Hans Magnus Enzensberger (1929). Alemanha. Poeta, ensaísta, tradutor e editor. Enzensberger é considerado por muitos o maior poeta vivo da língua alemã. Cresceu em Nuremberg, terra natal do nazismo, tendo se alistado na Juventude Hitlerista, da qual foi expulso em pouco tempo. Causou impacto e polêmica, já a partir de sua primeira publicação, "Verteidigung der Wölfe gegen die Lämmer" [Defesa dos lobos contra os cordeiros, 1957], poema que apresentava um tom forte de revolta política. Demonstrou, a partir dessa publicação, ser contra o que restava da Alemanha nazista e também contra aquilo em que a Alemanha ia aos poucos se tornando na época. Discípulo de Theodor W. Adorno e Max Horkheimer, um dos seus trabalhos de caráter político mais conhecido e polêmico foi sua teoria sobre a indústria das comunicações e mídia, expressa em Kit de construção para uma teoria da mídia, 1970. Em tempos de grande difusão das redes sociais, Enzensberger afirma que diante da impossibilidade de fazer desaparecer a manipulação da informação, a única saída seria que todos se tornassem manipuladores, evitando assim a passividade de um mero espectador. Um de seus conceitos mais conhecidos por quem discute seu trabalho é o de Weltekel, que significa nojo do mundo e parece constituir-se em uma radical crítica ao que ele considera ser uma passividade observada na política contemporânea por parte dos cidadãos.

28. Hans Werner Richter (1908-1993). Alemanha. Escritor. Richter é pouco conhecido pelo seu próprio trabalho literário, ganhou fama e reconhecimento internacional por ter ajudado a fundar o Grupo 47, a mais importante associação literária da Alemanha no pós-guerra. Um dos seus trabalhos mais importantes pelo caráter antiguerra foi o romance O Derrotado, 1949.

29. Hermann Muthesius (1861-1927). Alemanha. Inicialmente estudou filosofia e arte, em Weimar, mudando depois para o curso de arquitetura na Technische Hochschule Charlottenburg. Enquanto estudava, colaborou também no Ateliê de Paul Wallot. Após concluir os estudos foi mandado para Tóquio, onde planejou e executou seu primeiro projeto, uma igreja protestante alemã. Viveu em Londres entre 1896 e 1903. Hermann Muthesius era um entusiasta da arquitetura doméstica inglesa na qual baseava os seus projetos, tendo mesmo publicado um 
livro sobre o assunto, Das Englische Haus, 1904, que influenciou bastante a arquitetura doméstica tanto na Alemanha como na Inglaterra. O fascínio de Muthesius devia-se à simplicidade e utilidade observadas nesse tipo de arquitetura e nos seus artefatos. Além do livro citado escreveu ainda Die Schöne Wohnung, 1922. Muthesius teve intensa participação no chamado Projeto Werkbund. Seu confronto com Henry van de Velde nas questões de orientação do Werkbund alemão é considerado um dos fundamentos do design moderno.

30. Henry van de Velde (1863-1957). Bélgica. Arquiteto, designer e pintor ligado ao movimento estético conhecido como Art Nouveau. Estudou pintura na Academia de Belas Artes de Anvers, de 1881 a 1883, foi para Paris, em 1884, onde conheceu e tornou-se amigo de Monet, Pissarro, Mallarmé, Verlaine e Debussy. Em 1898 abriu a Société Van de Velde, empresa especializada em mobiliário e objetos para decoração de interiores. Em 1906, abriu a Escola de Artes e Ofícios de Weimar (Kunstgewerbeschule), que originaria a Bauhaus depois da guerra. Em 1907, colaborou na fundação do Deutscher Werkbund, onde entrou em conflito, posteriormente, com a orientação preconizada por Muthesius. Em 1922, construiu sua própria casa, valendo-se de métodos de pré-fabricação. De 1926 a 1935, dirigiu o Instituto Superior de Artes Decorativas de Bruxelas e, construiu o pavilhão belga na Feira Mundial de Nova York (1939-1940). Participaram da feira diversos países, incluindo o Brasil, com um pavilhão projetado por Lúcio Costa e Oscar Niemeyer. Compareceram ao evento aproximadamente, 44 milhões de pessoas.

31. A República de Weimar (1919-1933) é o nome dado ao regime que se estabeleceu na Alemanha, a partir do final da Primeira Guerra Mundial, e durou até a ascensão do partido nazista ao poder. O período foi marcado por grande descontentamento da população, já que o país vivia uma grave crise econômica, política e social devido às exigências de compensação feitas pelos países vitoriosos da Primeira Guerra Mundial. O Tratado de Versalhes limitava o ressurgimento econômico do país, com restrições à indústria e ao exército. A República de Weimar é dividida pelos historiadores em três fases: instabilidade política (1919-1923), recuperação e estabilização (1923-1929) e uma nova fase de crise, decorrente da quebra da bolsa de Nova York, que culminou com a ascensão de Hitler (1929-1933).

32. João Guimarães Rosa (1908-1967). Brasil. Contista, novelista, romancista e diplomata. Formou-se em medicina pela Universidade de Minas Gerais. Sua estreia literária aconteceu em 1929 com a publicação do conto "O mistério de Highmore Hall" na revista $O$ Cruzeiro. Diplomata, por concurso, trabalhou na Alemanha, Colômbia e França, voltando para o Brasil em 1951. Apesar de ter vivido muitos anos fora do país, sua literatura ganhou destaque pelo regionalismo, retratando principalmente o sertão do Brasil com uma linguagem inovadora e uma estrutura narrativa singular. A obra de Guimarães Rosa se destaca pela criação de muitos vocábulos feitos a partir de arcaísmos e palavras populares, assim como pelas suas invenções sintáticas, possibilitadas pelo seu trabalho de imersão nesse ambiente. Grande sertão: veredas, 1956, é um dos mais importantes textos da literatura brasileira. Em 1963, João Guimarães Rosa foi eleito para a Academia Brasileira de Letras.
33. Jean-Paul Sartre (1905-1980). França. Filósofo existencialista. A exemplo do que ocorreu com a dialética, o senso comum interpretou Sartre como o criador do existencialismo, o que não é correto. Ele afirmava que a existência precedia a essência. Assim, o existencialismo poderia ter seu início em Kierkegaard (1813-1855), antes com Pascal (1623-1662), ou até mesmo com Santo Agostinho (354-430). Trata-se da inversão de um tipo de pensamento filosófico. Desde Platão, o universal precedeu o particular. No pensamento existencial, a existência entra na discussão filosófica, partindo de questões cotidianas e caminhando em direção à universalidade. Sartre fez seus estudos secundários em Paris, onde conheceu Paul Nizan. De 1922 a 1924, estudou no curso preparatório do Lycée Louis-le-Grand, e aí surgiu seu interesse pela filosofia, influenciado pela obra de Henri Bergson. Ingressou na École Normale Supérieure, em 1924, quando conheceu Simone de Beauvoir, que se tornaria sua companheira e colaboradora até o fim de sua vida. Apresentado à fenomenologia de Husserl por Raymond Aron, Sartre ficou fascinado por essa escola que permitia estudar filosoficamente cada aspecto da vida humana. Foi a Berlim, como bolsista do Institut Français, onde conheceu a obra de Martin Heidegger, que se tornaria a base da primeira fase de sua carreira filosófica. De 1936 a 1939, ele ensinou no Havre e em Paris. Nessa época escreveu suas primeiras obras filosóficas: L'Imagination, 1936, e La Transcendence de l'égo, 1937. Em 1938, publicou La Nausée, um romance que é uma espécie de estudo de caso existencialista e que apresentava algumas das ideias que ele posteriormente desenvolveria em sua obra filosófica. No ano seguinte, Sartre se engajou no exército francês, e serviu na Segunda Guerra Mundial. Foi aprisionado em 1940 pelos alemães, e permaneceu preso até 1941. De volta a Paris, aderiu à Resistência Francesa, e tornou-se amigo de Albert Camus, amizade que perdurou até 1952, quando romperam publicamente devido à publicação por Camus de $\mathrm{O}$ Homem revoltado, livro no qual atacou o marxismo e a URSS. Sartre defendia uma relação de colaboração crítica com a URSS e publicou uma resenha desastrosa sobre o livro do Camus em sua revista Les Temps Modernes, respondida por Camus de maneira extremamente dura. Mas até o final da vida Sartre admirou Camus, como ele mesmo expressou nas entrevistas que teve com Simone de Beauvoir, em 1974, publicadas postumamente. L'Être et le néant, ensaio de ontologia fenomenológica de 1943, condensou todos os conceitos importantes da primeira fase de seu sistema filosófico. Em 1945, ele criou e dirigiu, com Merleau-Ponty, a revista Les Temps Modernes. Na década de 1950, aderiu ao comunismo, tornou-se ativista, e posicionou-se em defesa da libertação da Argélia. A aproximação quase incondicional ao marxismo marcou a segunda parte da sua carreira filosófica, em que tentou conciliar as ideias existencialistas de autodeterminação com os princípios marxistas. Escreveu sua segunda obra filosófica de grande porte, La Critique de la raison dialectique, 1960, em que defendeu os valores humanos presentes no marxismo, e apresentou uma versão alterada do existencialismo tentando resolver as contradições entre as duas concepções de vida. Considerado por muitos o símbolo do intelectual engajado, Sartre adaptava sempre sua ação às suas ideias, e o fazia sempre como ato político. Les Mots, um relato autobiográfico, escrito em 1963 e publicado um ano depois, foi sua despedida da literatura. Em 1964, recusou o Prêmio Nobel de Literatura, pois, segundo ele, "nenhum escritor pode ser transformado em instituição". Em 1968, aderiu aos mo- 
vimentos estudantis de protesto e foi para as barricadas das ruas de Paris. Morreu em 15 de abril de 1980. Seu funeral foi acompanhado por mais de cinquenta mil pessoas.

34. Paul Ives Nizan (1905-1940) foi um romancista, ensaísta, jornalista e tradutor francês. Filho de um engenheiro ferroviário, Paul Nizan fez seus estudos secundários em Paris, no Lycée Henri-IV, onde conheceu Jean-Paul Sartre, em 1917. Aceito na École Normale Supérieure em 1924, também estabeleceu ligações de amizade com Raymond Aron e Merleau-Ponty. Em 1925, participou do primeiro partido fascista francês, Le Faisceau, de Georges Valois, de orientação sindicalista e revolucionária. No ano seguinte, partiu para Aden, no Yémen, para trabalhar como preceptor. Pouco depois, aderiu ao Partido Comunista Francês e se casou com Henriette Alphen (1907-1993), uma prima de Claude Lévi-Strauss. Em 1929, Nizan tornou-se professor de filosofia do ensino médio. Em 1931, publicou Aden Arabie, tornando-se conhecido no meio literário. Em 1932, apresentou-se como candidato do Partido Comunista às eleições legislativas. No mesmo ano, publicou Les Chiens de garde, uma reflexão sobre o papel e a temporalidade da filosofia. O ensaio foi quase um manifesto contra seus antigos professores, particularmente Henri Bergson e Léon Brunschvicg, e também atacou os filósofos idealistas, na figura de Julien Benda, rotulando-os de cães de guarda da burguesia. Em 1933, publicou Antoine Bloyé, sua primeira evocação do tema da traição de classe (como um homem escapa da sua condição social e acaba por trair suas origens). O livro é considerado pela crítica como o primeiro romance francês filiado ao realismo socialista. Entre 1934 e 1935, Nizan e sua mulher passaram um ano na URSS. Ele participou do primeiro congresso da União dos Escritores Soviéticos e foi também encarregado de organizar a estada de escritores amigos, como André Malraux, Louis Aragon e outros. Suas publicações se sucederam nos anos seguintes: Le Cheval de Troie, La Conspiration. Além de livros, escreveu também para vários jornais e revistas de orientação comunista, como L'Humanité e o Ce soir, principalmente artigos sobre política internacional e crítica literária. Em agosto de 1939, denunciou a assinatura do pacto germano-soviético, por julgá-la uma aliança entre nazistas e comunistas. Pouco depois, ele rompeu com o PCF. Paul Nizan morreu, em 23 de maio de 1940, no início da Segunda Guerra Mundial, durante a ofensiva alemã contra Dunkerque. Após sua ruptura com o comunismo, Nizan sofreu ataques violentos dos comunistas: em março de 1940, Maurice Thorez, secretário-geral do PCF, assinou, no jornal Die Welt (edição alemã do órgão da Terceira Internacional), um artigo intitulado "Les Traîtres au pilori", acusando Nizan de ser agente da polícia. Durante a ocupação alemã, um texto do PCF, então na clandestinidade, falava ainda do "policial Nizan". Os ataques se intensificaram após a guerra. Louis Aragon participou ativamente da marginalização de Nizan no romance Les Communistes, 1949, colocando-o como traidor, retratado como o policial Orfilat. A reedição, em 1960, prefaciada por Jean-Paul Sartre, iniciou a reabilitação de Nizan. Na reedição de 1966, Aragon suprimiu o personagem Orfilat. No final dos anos 70, o PCF aceitou rever as acusações que havia feito a Paul Nizan. JeanPaul Sartre, Merleau-Ponty e Raymond Aron, entre outros, companheiros de escola e de pensamento livre, reestabeleceram sua memória.
35. O Museu de Artes de São Paulo MASP, fundado em 1947, foi idealizado pelo jornalista e empresário Assis Chateaubriand e pelo jornalista e crítico de arte italiano Pietro Maria Bardi. As primeiras obras foram selecionadas pessoalmente pelos dois, em visitas feitas às principais capitais culturais da Europa no pós-guerra. Primeiramente instalado no prédio dos Diários Associados, que pertencia a Chateaubriand, o museu teve sua sede própria projetada por Lina Bo Bardi e instalada na avenida Paulista, com uma vista então privilegiada do Centro da cidade e da Serra da Cantareira. Foram 12 anos entre o projeto e a execução; em 1968 foi inaugurado. O acervo do MASP é tombado pelo Patrimônio Histórico e Artístico Nacional IPHAN desde 1969 e atualmente possui cerca de 8.000 obras. Integra o Clube dos 19, do qual participam os museus que têm os acervos de arte europeia mais representativos do século XIX.

36. Walter Zeischegg (1917-1983). Áustria. Escultor, designer. Foi professor de projeto de produto na HfG-Ulm de 1954 até 1968. Trabalhou com Max Bill no período de estruturação da Escola de 1951 a 1954.

37. Ernst Moeckl (1931-2013). Alemanha. Designer industrial. Estudou na HfG-Ulm e foi colega de Bergmiller tanto nos estudos como no trabalho desenvolvido no Ateliê de Max Bill. Desenvolveram juntos o projeto de cadeira desmontável em metal cromado, couro e madeira, incluído posteriormente na coleção de design do MoMA, Museum of Modern Art, New York.

38. Wilhelm Wagenfeld (1900-1990). Alemanha. Designer industrial. Estudou sob a direção de László Moholy-Nagy, na Bauhaus, e em 1925 tornou-se assistente da oficina de metal e, posteriormente, seu chefe. Ele acreditava que os objetos domésticos deveriam ser baratos o suficiente para os trabalhadores e bom o suficiente para os ricos. Um de seus projetos clássicos é a luminária de mesa conhecida como Wagenfeld Lampe, [1924]. Seu famoso conjunto para chás, desenhado em 1938, continua sendo produzido até hoje.

39. O edifício do Ministério da Educação e Saúde MES é considerado um marco da arquitetura moderna do Brasil. Foi projetado por um grupo de arquitetos liderados por Lúcio Costa do qual participavam Affonso Eduardo Reidy, Carlos Leão, Jorge Moreira, Ernani Vasconcellos e Oscar Niemeyer, todos afinados com as linhas mestras do racionalismo arquitetônico modernista e conhecedores da obra de Le Corbusier, arquiteto franco-suíço, grande disseminador da arquitetura moderna nas primeiras décadas do século XX. Os cinco elementos que definem o programa arquitetônico corbusiano são: os pilotis, a planta livre, o terraço-jardim, a fachada livre e as janelas horizontais. Le Corbusier trabalhou como consultor do projeto, a convite de Lúcio Costa, assessorando diretamente todo o plano do ministério. O edifício reflete os preceitos racionais da arquitetura defendida por ele, incorporando também experiências realizadas pela escola carioca. Hoje o edifício tem o nome de Palácio Gustavo Capanema, em homenagem a seu idealizador, o ministro de Educação e Saúde de Getúlio Vargas, durante o Estado Novo. 
40. O conjunto arquitetônico da Pampulha, que fica em Belo Horizonte, Minas Gerais, foi projetado por Oscar Niemeyer sob encomenda de Juscelino Kubitschek, na época prefeito da cidade. O objetivo era desenvolver uma área ao norte da cidade, chamada Pampulha e, para isso, foi encomendado ao então jovem e já reconhecido arquiteto o projeto de um conjunto de prédios no entorno do lago artificial que existia no local. O complexo consiste em um cassino, uma igreja, uma casa de baile, um clube e um hotel. A construção aconteceu entre 1942 e 1944.

41. Roberto Simonsen (1889-1948). Brasil. Engenheiro, empresário, diplomata, escritor e político. Formou-se em engenharia civil na Escola Politécnica de São Paulo, em 1909. Poucos anos depois, fundou a Companhia Construtora de Santos no ramo da construção civil. Ampliou seus negócios, passando a investir em outros ramos da indústria. Em 1916, fundou o Centro de Construtores e Industriais de Santos, que oferecia assistência aos trabalhadores e inovava as relações entre patrão e empregado no Brasil, instituindo pela primeira vez uma junta de conciliação. Suas ideias e propostas sobre o rumo da economia brasileira ganharam prestígio. Ele defendia a participação de capitais e tecnologias estrangeiras no desenvolvimento econômico do país. Em 1932, Simonsen assumiu papel de destaque na direção do Movimento Constitucionalista de São Paulo. Durante o Estado Novo, colaborou ativamente com o Governo. Com o fim do Estado Novo e a redemocratização do país, ingressou no Partido Social Democrático (PSD), pelo qual se elegeu senador por São Paulo, em 1947. Um ano antes, havia se tornado o primeiro economista a conquistar uma cadeira na Academia Brasileira de Letras. Escreveu diversos textos e livros, entre eles a História econômica do Brasil, 1937, considerada uma obra de referência sobre o tema.

42. Irineu Evangelista de Sousa (1813-1889). Brasil. Industrial, político, banqueiro e diplomata. Pela sua contribuição com a industrialização do país no período do Império, recebeu os títulos nobiliárquicos, primeiro de Barão e depois de Visconde de Mauá. É um pioneiro na área da industrialização, por implementar em suas empresas maquinário e recursos aplicados na Europa e nos Estados Unidos durante a Revolução Industrial. Foi um dos grandes opositores da escravidão, porque acreditava que somente com comércio e trabalhadores livres o Brasil poderia prosperar. Foi pioneiro também no campo dos serviços públicos: fundou uma companhia de gás para a iluminação pública do Rio de Janeiro [1851], organizou as companhias de navegação a vapor no Rio Grande do Sul e no Amazonas [1852], implantou a primeira estrada de ferro, de Raiz da Serra à cidade de Petrópolis RJ [1854], inaugurou o trecho inicial da União e Indústria, primeira rodovia pavimentada do país, entre Petrópolis e Juiz de Fora [1854]. Liberal, abolicionista e contrário à Guerra do Paraguai, forneceu os recursos financeiros necessários à defesa de Montevidéu, quando o governo imperial decidiu intervir nas questões do Prata [1850] e, assim, começou a ter problemas políticos no Império.

43. Após a derrota da Revolução Constitucionalista de 1932, um grupo da elite paulista decidiu fundar a Escola Livre de Sociologia e Política ELSP. Segundo descrito no manifesto de fundação, publicado no jornal O Estado de S. Paulo no dia 16 de abril de 1933, os intelectuais paulistas perceberam a falta de uma "elite numerosa e organizada, instruída sobre métodos científicos, a par das instituições e conquistas do mundo civilizado, capaz de compreender antes de agir o meio social em que vivemos". Como disse Sérgio Milliet, um dos fundadores da escola, "de São Paulo não sairão mais guerras civis anárquicas", e sim "uma revolução intelectual e científica suscetível de mudar as concepções econômicas e sociais dos brasileiros". Para ele, o ensino superior da época era "exclusivamente formal" e "produzia anualmente centenas de bacharéis inúteis e nenhum elemento de verdadeira cultura". A ELSP inspirou-se na sociologia norte-americana, estruturada principalmente nos princípios da chamada Escola de Chicago, onde predominava a pesquisa aplicada e foi a primeira a formar sociólogos e cientistas políticos no Brasil. Com menos de dois anos de existência, o projeto teve uma mudança de rumo. Em fevereiro de 1935, a Escola criada para ser uma fundação autônoma e viver de doações de empresários e dos recursos provenientes de seus cursos, recebeu uma nova configuração jurídica. O decreto de Armando Salles de Oliveira, interventor federal, transformou a faculdade em um órgão de utilidade pública, o que permitiria a ela receber verbas públicas. Também ganhou o status de "instituição complementar da USP". Em 1946, a Escola deixa de ser livre em sua própria denominação. Por decreto federal, ela foi reconhecida como curso de graduação, e o MEC tomou seu currículo como base para o ensino de sociologia no país.

44. Juscelino Kubitschek (1902-1976). Brasil. Médico e político. Conhecido como JK, foi prefeito de Belo Horizonte [1940-1945], governador de Minas Gerais [1951-1955] e presidente do Brasil [1956-1961]. Foi o responsável pela mudança da capital do país, do Rio de Janeiro para Brasília. Tinha como objetivo o desenvolvimento do interior do Brasil e a integração do país. Em 1957, em concurso organizado por Oscar Niemeyer, foi aprovado o plano-piloto de autoria do arquiteto e do urbanista Lúcio Costa para a construção de Brasília. A nova capital foi inaugurada pelo presidente em 1960. JK foi o primeiro presidente civil a cumprir todo o seu mandato, desde Artur Bernardes, tendo habilidade política para conciliar os diversos setores da sociedade. Com o seu slogan "50 anos em 5", lema do Plano Nacional de Desenvolvimento, também conhecido como Plano de Metas, ele conquistou a simpatia e confiança da população. Seu processo de rápida industrialização do país se dividia em cinco grande grupos: energia, transporte, alimentação, indústria de base e educação. Durante o seu governo, houve grande crescimento econômico, mas também um grande aumento da dívida pública interna e da dívida externa, o que fez com que os seus sucessores, Jânio Quadros e João Goulart, tivessem que lidar com a alta da inflação.

45. Sérgio Buarque de Holanda (1902-1982). Brasil. Historiador, crítico literário e jornalista. Formou-se em direito pela Universidade do Brasil, atual Universidade Federal do Rio de Janeiro. Um ano depois, começou a trabalhar como jornalista no Espírito Santo. Em 1927 voltou para o Rio de Janeiro e passou a trabalhar como colunista do Jornal do Brasil. Como correspondente dos Diários Associados, fixou nova residência em Berlim. De volta ao Brasil, em 1936, ingressou na Universidade do Distrito Federal como professor assistente. No mesmo ano lançou seu livro Raízes do Brasil. Em 1947, filiou-se ao Partido Socialista e assumiu a vaga de professor de História Econômica do Brasil, na Escola de Sociologia e Política, em substituição a Roberto Simonsen. Em concurso público se tornou professor da cadeira de História da Civilização 
Brasileira na Faculdade de Filosofia, Letras e Ciências Humanas da USP. Durante a ditadura militar requereu aposentadoria do cargo em solidariedade aos colegas afastados de suas funções pelo Al-5. Entre suas obras mais famosas, além de Raízes do Brasil, estão Cobra de vidro, 1944; Caminhos e fronteiras, 1957, e Visão do paraíso, 1959.

46. Alexandre Wollner (1928-2018). Brasil. Designer gráfico. Um dos principais referenciais do design gráfico brasileiro. Foi aluno da primeira turma do Instituto de Arte Contemporânea do Museu de Arte de São Paulo (IAC/MASP). Segundo seu depoimento de Wollner em 2003, o curso era "um centro de estudo e divulgação dos princípios das artes plásticas, visando formar jovens que se dediquem à arte industrial". Em 1953, foi estudar na Escola de Ulm. Estagiou no escritório de Otl Aicher, participando de projetos da Braun, Lufthansa e Herman Miller. Voltou para o Brasil na época em que Juscelino Kubitschek viabilizou seus planos para o desenvolvimento industrial do país. Junto com Geraldo Barros, Rubem Martins e Walter Macedo, abriu o primeiro escritório de design do país, o Formlnform. Em 1962, junto com Aloísio Magalhães (1927-1982), inicia um curso de tipografia no Museu de Arte Moderna do Rio de Janeiro MAM/RJ. A experiência é o embrião da Escola Superior de Desenho Industrial ESDI, a primeira instituição de nível superior em design do país, fundada um ano depois. Entre os projetos de identidade visual que desenvolveu, destacam-se Equipesca, Itaú, Elevadores Atlas, Sardinhas Coqueiro, Ultragás, Philco, Hering.

47. Almir Mavignier (1925-2018). Brasil. Pintor e designer gráfico formado pela Escola de Ulm. Fundou o Ateliê de Pintura e Modelagem da seção de terapêutica ocupacional do hospital psiquiátrico do Engenho de Dentro (atual Museu de Imagens do Inconsciente) com a psiquiatra Nise da Silveira. Durante esse trabalho, Mavignier reunia-se com outros jovens para tentar compreender como pacientes, que não tinham nenhum contato com técnicas ou teorias artísticas, produziam obras de arte. O seu interesse pela linguagem não figurativa foi despertado pelo contato com o crítico Mário Pedrosa. Junto com Ivan Serpa e Abraham Palatnik, criou o primeiro núcleo de pintura abstrata do Rio de Janeiro. Em visita a uma exposição de Max Bill, em São Paulo, Mavignier entrou em contato com a produção construtiva, que influenciou seu trabalho. Em 1954, ingressou na primeira turma da Escola de Ulm, onde estudou comunicação visual e foi colega de Alexandre Wollner e Karl Heinz Bergmiller.

48. Mary Vieira (1927-2001). Brasil. Escultora e professora. Estudou pintura e desenho com Guignard na Escola de Belas-Artes de Belo Horizonte e escultura com Franz Weissmann e Amílcar de Castro. Em 1948, produziu suas primeiras esculturas eletromecânicas, fruto da realização de pesquisas sobre o movimento e a dinâmica das formas. Na mesma ocasião ela criou um conjunto feito em madeira com o nome de Multivolumes. No ano seguinte, fez as primeiras peças do conjunto chamado de Polivolumes, que consistiam em uma parte sólida com segmentos móveis e assumiam múltiplas configurações ao serem manuseadas pelo observador. Em 1951 ela se mudou para a Suiça, onde aprimorou seu conhecimento ao lado de Max Bill e a seu convite participou do grupo Allianz, constituído por artistas com tendências construtivistas. A partir de 1966, tornou-se professora da Escola Superior de Arte, Técnicas de Planejamento Gráfico e Desenho Industrial, da Universidade da Basileia, Suíça.
Várias de suas obras estão instaladas em locais públicos no Brasil e no exterior, como na praça Rio Branco, em Belo Horizonte, no Parque Ibirapuera, em São Paulo e no Ministério das Relações Exteriores, em Brasília.

49. Yedda Lúcia Pitanguy (1931-1996). Brasil. Arquiteta. Formou-se em arquitetura na Universidade Federal do Rio de Janeiro UFRJ. Estudou na HfG-Ulm, sendo colega de Bergmiller e de outros brasileiros que também estudavam lá na mesma época, como Alexandre Wollner e Almir Mavignier. Especializou-se em planejamento urbano e fez mestrado na COPPE/UFRJ, pesquisando o efeito da urbanização no meio ambiente, especificamente nas lagoas de Araruama e Iguaba no litoral do Rio de Janeiro. Foi superintendente de Desenvolvimento Urbano do Estado do Rio de Janeiro. Lecionou na Universidade Santa Úrsula.

50. Frauke Koch Weser. Alemanha. Designer Industrial. Sua família se mudou para o Brasil após a ascensão do nazismo. Seu pai, Erich Koch-Weser, era um político liberal, ligado à social democracia da República de Weimar e a família tinha ascendência judaica. Estabeleceram-se no Paraná e com a queda do regime nazista os três filhos voltaram para estudar na Alemanha. Frauke e sua irmã Elke estudaram em Ulm ao lado de colegas brasileiros: Almir Mavignier, Alexandre Wollner e Karl Heinz Bergmiller. Casou-se com seu colega de turma e arquiteto suíço Paul Edgard Decurtins, que viria ao Brasil participar como professor dos primeiros anos de funcionamento da ESDI.

\section{a influência de Max Bill}

51. Walter Gropius (1883-1969). Alemanha. Arquiteto, desenhista industrial, professor. Seu núcleo familiar certamente determinou sua vocação. Seu pai era um arquiteto que ocupava importante posição oficial. Seu avô, Carl Wilhelm Gropius era um conhecido pintor que frequentava o círculo de amigos do célebre arquiteto Karl Friedrich Schinkel e seu tio, Martin Gropius, também arquiteto, dirigiu a Escola de Artes e Ofícios de Berlim. Iniciou seus estudos de arquitetura em Munique em 1903 e, posteriormente, em Berlim de 1905 a 1907 na Escola Técnica Superior, de onde saiu com diploma de engenheiro construtor. Entre 1910 e 1914, dirigiu o próprio escritório, estabelecendo sociedade com Adolf Meyer, realizando em 1914 o projeto da Fábrica Fagus, em Altfeld. Passou a interessar-se pela construção pré-fabricada. Ao retornar da guerra em 1918, aderiu ao Grupo Novembro e ao Conselho de Trabalho para a Arte. No ano seguinte fundou e passou a dirigir a Bauhaus, permanecendo no cargo até 1928. Em seus últimos anos de vida, assim como em 1919, ele combatia a ideia de uma civilização técnica opressiva contra a harmonia do homem e da natureza. Preocupavam-no, especialmente, os problemas das cidades sujeitas aos processos de construção gerados por uma cultura de industrialização a qualquer custo e pela consequente especulação imobiliária. Uma das principais personalidades da arquitetura e do próprio Movimento Moderno, em seus textos e palavras revelou-se também intransigente idealista, podendo ser considerado uma das referências moralistas da arquitetura e do design contemporâneos. Principais obras: a Fábrica Fagus [1911]; o edifício sede da Bauhaus em Dessau [1925]; o edifício prismático PANAM, com 59 andares, em New York [1958-1963], posteriormente denominado MetLife; o Bauhaus Archiv [1961] e a Fábrica de Vidros Thomas, em Amberg [1967-1969]. 
52. Hannes Meyer (1889-1954). Suíça. Entre 1904 e 1907 foi aprendiz de pedreiro e mestre em construção em pedra enquanto frequentava cursos de artes aplicadas. Em 1909, estudou urbanismo em Berlim. De 1912 a 1913, viajou pela Inglaterra observando e estudando as cidades jardins e no período de 1923 -1927, viajou pela Europa realizando trabalhos de militância política comunista. Em 1927, foi chamado por Walter Gropius e nomeado professor de arquitetura na Bauhaus e um ano depois, tornou-se diretor da escola indicado por Gropius. Permaneceu no cargo até 1930 tendo reformado o programa de estudos e introduzido no currículo disciplinas como ciências naturais, ciência técnicas e urbanismo. Deixou a Bauhaus pressionado por forças internas que não viam com agrado a militância política de Meyer, o que favorecia o surgimento de células políticas de esquerda dentro da escola. A correspondência de Gropius com Tomás Maldonado, publicada na revista ulm no 10/11 (1964), é bastante elucidativa do ponto de vista de Gropius sobre a ação de Meyer nessa ocasião. O próprio Meyer poucas oportunidades teve para dar a sua versão. Viajou para Rússia onde trabalhou, entre 1930 e 1936, como urbanista e arquiteto chefe da comissão de arquitetura para as escolas superiores e técnicas, membro consultivo do Instituto Nacional de Urbanismo, e professor da Escola Superior de Arquitetura. Apesar dos títulos e das deferências, a Rússia já estava em pleno encaminhamento para o stalinismo e Meyer não viu nenhuma possibilidade para desenvolver qualquer trabalho criativo no país. Retornou à Suíça, em 1936, e dois anos depois foi para o México, onde o esperavam mais deferências e títulos, concedidos por uma revolução falida e escamoteada de suas raízes populares. Apesar disso, ele permaneceu no país até 1949, dirigindo uma nova seção de urbanismo no Instituto Politécnico e trabalhando em comissões de planejamento de habitação, de clínicas de saúde e de escola. Retornou à Suíça em 1949. Escreveu o livro El Arquiteto y la lucha de classes y otros escritos, publicado pela Gustavo Gili em 1972.

53. Mies van der Rohe (1896-1969). Alemanha. Começou sua carreira muito jovem, trabalhando com Bruno Paul em Berlim. Entre 1908 e 1911, trabalhou no escritório de Peter Behrens, onde conheceu Walter Gropius, e depois de 1912 a 1914 como arquiteto autônomo, também em Berlim. Posteriormente abriu seu escritório na capital alemã, trabalhando até 1938. No período de 1926 a 1932, foi vice-presidente do Deutscher Werkbund e, em 1927, organizou a exposição "Werkbund" em Stuttgart. Em 1929, construiu o pavilhão alemão na Exposição Universal de Barcelona. Foi diretor da Bauhaus de 1930 até o fechamento da escola em 1933. Emigrou para os Estados Unidos em 1938, quando foi nomeado diretor da seção de arquitetura do Armour Institute, que depois se tornou Illinois Institute of Technology. Estabeleceu seu escritório em Chicago, depois de 1958, exercendo intensa atividade de projeto em todo o território americano. Algumas de suas ideias -"Rejeitamos toda especulação estética, toda doutrina e todo formalismo". "A arte de construir é a vontade de uma época traduzida no espaço. Viva. Mutante. Nova". "Não podemos dar uma forma nem ao ontem e nem ao amanhã; podemos dar somente uma forma ao hoje". "Importa-nos liberar a construção das especulações estéticas e de recuperar o ato de construir como aquilo que ele deve ser essencialmente: construção".

54. Charles Eames (1907-1978). Estados Unidos. Estudou arquitetura na Universidade de Washington de modo irregular e pouco formal de 1921 a 1926. Logo a seguir e até 1935, dedicou-se a trabalhos que incluíram a construção de residências, pequenas igrejas, luminárias e outros variados projetos. Em 1941, casou-se com Ray Kaiser e com ela estabeleceu uma parceria de trabalho. Durante a Segunda Guerra Mundial, Eames fez pesquisas avançadas para escritórios especiais do Exército, tornando-se um grande conhecedor de materiais e tecnologia avançada. Em 1947, George Nelson aprovou a fabricação das cadeiras de Eames, que passou a trabalhar para a Herman Miller. Além dos trabalhos para essa firma, o casal Eames desenvolveu diversos outros tipos de atividades ligadas ao design e à comunicação, como filmes, exposições e publicações. Eames foi provavelmente o mais consistente designer moderno fora da esfera de influência alemã. Ao lado do grupo que com ele trabalhou na Herman Miller, e de Elliot Noyes, designer da IBM, e Florence Knoll, pode ser considerado um dos mais consistentes designers de produto americanos do século XX.

55. George Nelson (1908-1986). Estados Unidos. Estudou arquitetura em Yale (1928-1931) e na Escola de Belas-Artes de Paris em 1931. Em 1932 ganhou o Grande Prêmio de Arquitetura de Roma. Em 1946 tornou-se diretor de design da Herman Miller. Assim ele engajou Charles Eames e Alexander Girard, nessa firma, consolidando uma extraordinária equipe de design. Desenvolveu diversos móveis e linhas de mobiliário para a Herman Miller, construiu casas experimentais, os pavilhões da Exposição Americana em Moscou em 1957 e o Hotel Memorial de Sain-Lô na França, em 1956. Partidário de uma industrialização integral na construção, grande parte de suas pesquisas foi direcionada para a pré-fabricação e materiais mais adequados a essa técnica. Foi um analista crítico e sensível das consequências de tais processos e muitos de seus escritos são antecipatórios de problemas atuais dos processos de industrialização a qualquer custo.

56. Peter Behrens (1868-1940). Alemanha. Abandonou o estudo de pintura, em Karlsruhe e Dusseldorf (1986-1869), dedicando-se às artes gráficas e aplicadas baseadas no Art Nouveau. Pioneiro em responder à demanda da civilização industrial através da arquitetura, influenciou o Movimento Moderno na Alemanha e praticamente iniciou a atividade do desenho industrial como hoje é conhecida. Foi convidado pelo grão-duque de Hesse, Emil Ludwig, a juntar-se aos artistas da Colônia de Darmstadt, em 1899. Trabalhou na Allgemeine Elektrizitäts-Gesellschaft AEG, em projetos elétricos e na parte de comunicação visual e gráfica. Introduziu uma nova expressão para a monumentalidade da arquitetura europeia com o projeto da Fábrica de Turbinas da AEG, primeiro edifício alemão em aço e vidro [1908-1909] e do conjunto de apartamentos para os trabalhadores da AEG em Henningsdorf [1910-1911]. Também desenvolveu projetos para os escritórios Mannesmann AG em Dusseldorf [1911-1912], para Companhia Continental de Borracha [1913-1920] e a embaixada alemã em São Petersburgo [1911-1912]. Nomeado diretor da Escola de Arquitetura de Viena, em 1922, com uma produção considerada exemplar do Expressionismo Alemão, teve entre seus seguidores e colaboradores importantes arquitetos como Le Corbusier, Walter Gropius e Mies van der Rohe.

57. Herman Miller é uma empresa de móveis de escritório fundada a partir de outra empresa chamada Star Furniture Company que existia desde 1906 nos Estados Unidos. Dirk Jan De Pree, 
conhecido como DJ, que começou trabalhando como atendente na loja, aos 18 anos, e se tornou presidente, convenceu seu sogro, Herman Miller, a comprar a maioria das ações da empresa, que passou a ter seu nome. Na época, ela fabricava reproduções de móveis tradicionais. Com a crise de 1929, a Herman Miller foi obrigada a se reinventar e, com a ajuda do designer Gilbert Rohde, afastou-se do mobiliário tradicional e decidiu concentrar-se em produtos mais adequados às mudanças que estavam em voga. Em 1942, Rohde projeta um precursor dos sistemas de mobiliário para escritório, introduzindo a empresa nesse ramo. Após uma exposição intitulada "O novo mobiliário desenhado por Charles Eames", no Museu de Arte Moderna de New York, Charles e Ray Eames foram contratados para fazer parte da equipe. Em 2004, pela 16 vez em 18 anos, a Herman Miller é classificada como a empresa mais admirada na indústria de mobiliário pela pesquisa anual da revista Fortune. A revista apontou a Herman Miller entre as empresas mais inovadoras do mercado, colocando-a no $4^{\circ}$ lugar geral entre as quase 600 empresas pesquisadas.

58. Nelson Rodrigues (1912-1980). Jornalista, escritor e dramaturgo. Não há quem tenha tido contato com a polêmica obra de Nelson Rodrigues que seja indiferente a ela. E a ele. Ambos fortemente ligados. Nelson teve uma história de vida complicada e viveu a sua maturidade artística em uma época na qual a liberdade de expressão praticamente não existia. "Não admito censura nem de Jesus Cristo", dizia ele. Nascido em 1912, na cidade do Recife, Nelson Rodrigues tinha treze irmãos. Mudou-se para o Rio ainda criança, cidade que serviu de inspiração para suas obras: romances, contos, crônicas e peças teatrais. Típico carioca, torcedor fanático do Fluminense e jornalista, cresceu em um Rio em que vizinhas fiscalizavam a vida dos outros pela janela, usavam-se escarradeiras e o banho era de bacia. Nelson Rodrigues sempre teve um jeito diferente de enxergar a vida. A sua própria vida não fora nada fácil, o que refletiu em suas obras, que não descrevem os encantamentos da cidade maravilhosa, mas, sim, a podridão da vida humana. Chegou a ser considerado insano e foi internado. A crítica de tradicionais instituições sociais, como o casamento, por exemplo, são a base de uma literatura intensa, que até hoje causa polêmica. Ele teve peças censuradas por ousar mostrar nos palcos a intimidade das famílias brasileiras, que entre quatro paredes estavam destruídas, ainda que na esfera social, totalmente íntegras. Além disso, o sexo está presente em boa parte de suas obras, o que, para uma sociedade que se encontrava em uma mudança gradual, ainda foi um choque. Com uma linguagem muito característica, ele foi aos poucos desfigurando imagens construídas pela sociedade tradicional. Com isso, construiu sua própria imagem. Sua primeira peça foi $A$ Mulher sem Pecado, mas o sucesso veio com Vestido de Noiva, que trazia uma renovação nunca vista nos palcos brasileiros. Com três planos simultâneos - realidade, memória e alucinação - as inovações estéticas da peça iniciaram o processo de modernização do teatro brasileiro. Algumas de suas peças mais conhecidas são: Bonitinha, mas ordinária, Álbum de Família, O Beijo no Asfalto e Os Sete Gatinhos.

59. Gustavo Goebel Weyne Rodrigues (1933-2012). Brasil. Designer gráfico. Tipógrafo. Foi um dos professores fundadores da Escola Superior de Desenho Industrial ESDI, onde lecionou a partir de 1964. Estudou artes visuais no MASP, em São Paulo e no
MAM/RJ. Ao lado de Bergmiller, coordenou o estruturou o Instituto de Desenho Industrial do Museu de Arte Moderna do Rio de Janeiro IDI/MAM, e foi o responsável pela identidade visual na Escriba, empresa de móveis de escritório. Na Novacap, empresa responsável pela construção da nova capital brasileira, Brasília, teve a oportunidade de trabalhar ao lado de Oscar Niemeyer e desenvolveu um projeto gráfico e diagramação para a revista Módulo. Em seu trabalho, como professor da ESDI, prevaleceu o rigor, ao mesmo tempo em que estabeleceu com vários alunos uma relação entre mestre e aprendiz.

60. Renina Katz (1925). Brasil. Gravurista, desenhista, ilustradora e professora. Cursou a Escola Nacional de Belas Artes EBA e a Faculdade de Filosofia da Universidade do Brasil, no Rio de Janeiro. Foi aluna de gravura, em metal e madeira, de Carlos Oswald e Axel Lescoschek. Em 1952, mudou-se para São Paulo. Deu aulas de desenho e gravura no MASP e foi professora na Fundação Armando Álvares Penteado. Publicou seu primeiro álbum de gravuras, Favela em 1956. No mesmo ano se torna docente da Faculdade de Arquitetura e Urbanismo da Universidade de São Paulo FAU/USP, onde permanece por 33 anos. O caráter realista de suas gravuras iniciais, a crítica social, o universo dos trabalhadores urbanos, personagens marginalizados, é gradualmente substituído por um caráter não figurativo. "Todos os elementos contidos nas imagens que fiz nos anos 50 ainda são detectáveis nas atuais, não como temática, mas como forma de estruturação, de relações e tensões do espaço". Na ESDI, de 1968 a 1972, foi professora de Meios e Métodos de Representação. Em março de 2003, faz uma palestra no Contraponto - segundo seu idealizador, Sergio Fingermann, “Um lugar que propõe experiências". No texto publicado, dialoga de forma criativa e consistente sobre seu pacto poético: como uma necessidade primordial, a criação converte-se numa atividade.

61. Décio Pignatari (1927-2012). Brasil. Poeta, professor, tradutor e dramaturgo. Aos 22 anos, em 1949, publica seus primeiros poemas na Revista Brasileira de Poesia. No ano seguinte publica o primeiro livro, Carrossel. Em 1952, funda com seus amigos, que eram poetas e irmãos, Haroldo de Campos e Augusto de Campos, a revista-livro Noigandres criando os fundamentos da poesia concreta. O lançamento oficial aconteceu apenas em 1956. Décio considerou a Exposição Nacional de Arte Concreta realizada no Museu de Arte Moderna de São Paulo MAM/SP, em 1956 e no Rio de Janeiro no Ministério da Educação e Saúde, em 1957, com artistas das duas cidades como: "[...] o primeiro encontro nacional das artes de vanguarda realizado no país, tanto no que se refere às artes visuais quanto à poesia concreta". Na revista publicaram o ensaio "Plano-piloto para poesia concreta", síntese teórica de seu trabalho, traduzido em diversas línguas e juntos eles também publicaram, em 1965, o livro Teoria da poesia concreta. Pignatari, além de escrever poesia trabalhou também como teórico de comunicação, traduzindo obras de Marshall McLuhan, e publicando o ensaio Informação, linguagem e comunicação, 1968. A partir de 1964, ele foi professor de Teoria da Informação na ESDI.

62. Zuenir Ventura (1931). Brasil. Escritor e jornalista. Formou-se em letras neolatinas na Universidade do Brasil, atual UFRJ, iniciando sua carreira como jornalista logo em seguida. Zuenir foi repórter, editor e chefe de redação de veículos como as revis- 
tas Visão e Veja, o Jornal do Brasil e o site No mínimo. Em 1959, ganha uma bolsa de estudos do governo francês para estudar no Centro de Formação de Jornalistas, em Paris e ao mesmo tempo trabalha como correspondente da Tribuna da Imprensa, fazendo coberturas históricas, como a passagem de Jango pela capital francesa antes de se tornar presidente e o encontro de cúpula entre Kennedy e Kruschev, em Viena. Ao retornar ao Brasil, assume a editoria internacional no Correio da Manhã e começa a lecionar na ESDI, a disciplina de Comunicação Verbal. No ano de 1968, é preso e passa três meses em uma cela com pessoas influentes como Hélio Pellegrino, Ziraldo, Gerardo Mello Mourão e Osvaldo Peralva. Logo após ser libertado, lança 12 reportagens intituladas "Os anos 60 - A década que mudou tudo", que mais tarde se transformam em um livro. Em 1988, publica seu livro mais conhecido: 1968 - O ano que não terminou, best-seller que se torna inspiração para a minissérie da Rede Globo Anos Rebeldes. Em 1989, Zuenir ganha os prêmios Esso, de jornalismo e, Wladimir Herzog, de direitos humanos, devido a uma série de reportagens sobre o caso do seringueiro Chico Mendes, assassinado no Acre. Em 1983, após as chacinas da Candelária e de Vigário Geral, colabora para a criação do Viva Rio, uma organização não governamental dedicada a projetos sociais e campanhas antiviolência. No ano seguinte, lança o livro Cidade partida, um retrato das causas da violência no Rio, contando sua experiência na favela de Vigário Geral e, com isso, recebe o Prêmio Jabuti de Reportagem. Em 6 de março de 2015, toma posse como um imortal da Academia Brasileira de Letras, sucedendo a Ariano Suassuna.

63. O estilo ou conceito conhecido como streamlining surgiu nos Estados Unidos no contexto da quebra da bolsa de Nova York em 1929. Com a crise, a indústria precisou se reinventar para retomar a venda em massa de produtos industrializados. Ângulos retos foram substituídos por curvas, com base nos princípios de aerodinâmica e hidrodinâmica, que evoluíram a partir do avanço tecnológico nas áreas de aviação e balística. Com um design futurista que remetia à velocidade, os objetos eram feitos para serem atraentes e tentadores, o estilo era símbolo dos tempos melhores que viriam depois da crise e se popularizou nas décadas de 1940 e 1950 . O streamlining foi aplicado também na arquitetura, em projetos que se caracterizavam por curvas e linhas horizontais.

64. O styling surgiu no mesmo contexto do streamlining, e é uma filosofia do design atrelada a esse estilo. Pela necessidade de incrementar vendas depois da quebra da crise de 1929 nos EUA, a indústria assumiu como objetivo tornar o produto atraente para o consumidor valorizando a parte visual. Essa ideia teve entre seus principais difusores o designer Raymond Loewy.

65. Kitsch é um termo de origem alemã cujo significado e aplicação são controversos. É utilizado muitas vezes para categorizar objetos de valor estético distorcido e exagerado. Normalmente destinados ao consumo de massa, os objetos kitsch copiam referências culturais eruditas com um nível de qualidade mais precário. Sua origem não está totalmente esclarecida, uma das hipóteses é que o termo apareceu pela primeira vez no vocabulário dos artistas e colecionadores de arte em Munique, em torno de 1860 e 1870, com base em kitschen [atravancar],e verkitschen [trapacear; vender outra coisa no lugar do objeto combinado]. Além disso, outras palavras alemãs com a mesma terminação - tsch - comumente referem-se a coisas vulgares, ingênuas, sentimentais ou infantis. Dessa forma, desde o início seu significado está atrelado a um sentido pejorativo. Há no cotidiano uma profusão de objetos que podem ser considerados kitsch: souvenir turístico, miniaturas, adornos, objetos de decoração, talismãs, imãs e pinguins de geladeira, etc.

66. D’Arcy Thompson (1860-1948). Escócia. Biólogo e matemático. Foi um cientista famoso em sua época, ocupando importantes cadeiras universitárias durante 64 anos. Pioneiro na aplicação matemática à biologia, publicou mais de 300 trabalhos. De substantiva importância é o livro On Growth and Form,1917.

67. Hans Gugelot (1920-1965). Indonésia. Arquiteto e desenhista industrial alemão. Estudou em Lausanne e Zurique. Realizou diversos estágios de arquitetura, inclusive com Max Bill, na Suíça, onde desenvolveu o plano urbano de um quarteirão pré-fabricado. De 1952 a 1953, realizou os primeiros protótipos de um sistema de móveis para escritório denominado M-125, com características modulares e de componibilidade inovadoras. Em 1954, tornou-se professor da HfG-Ulm e, em 1957, designer consultor da firma Braun. Em 1962, abriu um escritório próprio. De 1961 a 1965 , foi professor convidado no National Institute of Design NDI de Ahmedabad, na Índia, e consultor para a implantação dessa escola. No livro Hochschule für Gestaltung Ulm: Die Moral der Gegenstände, 1987, Gui Bonsiepe situa a Escola de Ahmedabad e a ESDI, como uma consequência do desenvolvimento do modelo Ulm nos países periféricos.

68. Herbert Ohl (1926). Alemanha. Estudou gráfica e pintura na Academia de Belas Artes de Karlsruhe, arquitetura na Universidade de Karlsruhe, graduando-se arquiteto pelo Politécnico de Milão. Professor na HfG-Ulm, desde 1958, foi seu reitor de 1965 até 1968. Professor visitante na Universidade de Columbia, em Harvard, Cambridge, Carnegie Institute of Technology, Universidade da Califórnia, Texas Art University, National Institute of Design, Ahmedabad, Índia. Tem vários projetos desenvolvidos como arquiteto e designer para a indústria alemã e italiana.

69. O Museu de Arte Moderna do Rio de Janeiro MAM/RJ foi criado em 1948 e se instalou provisoriamente no Banco Boavista na Candelária. O pós-guerra favoreceu a aquisição de obras de artistas europeus, como Picasso, Kandinsky e Paul Klee. A primeira exposição, "Pintura europeia contemporânea", acontece no ano seguinte. Em 1952, o museu se instala no Palácio Gustavo Capanema, na época sede do Ministério de Educação e Saúde. No mesmo ano, a Câmara dos Vereadores aprova a proposta de doação de um terreno de 40 mil metros quadrados para a instituição, que está neste local até hoje. O arquiteto e urbanista Affonso Eduardo Reidy projeta o prédio do Museu de modo a interferir o mínimo possível na paisagem e do seu interior com ela gerar um diálogo. Roberto Burle Marx projeta os jardins. O Bloco Escola é inaugurado em 1958 e passa a ser a sede do Museu. Em 1965, o MAM é tombado juntamente com o Parque do Flamengo pelo Instituto do Patrimônio Histórico e Artístico Nacional IPHAN. A conclusão da construção do bloco de exposições acontece apenas em 1967 e a mostra inaugural é uma retrospectiva de Lasar Segall. Em 1978, um incêndio destrói praticamente toda a coleção do Museu. A reabertura do Bloco de Exposições, muito danificado, aconteceria somente quatro anos depois. 


\section{a formação em Ulm}

70. Josef Albers (1888-1976). Alemanha. Estudou de 1913 a 1920 na Kunstschule de Berlim, posteriormente em Essen e em Munique. Foi para a Bauhaus, em 1920, estudando até 1923. Interessou-se inicialmente pela pintura em vidro, criando sua primeira obra significativa nos vitrais para a casa de Adolf Sommerfeld. Foi professor do Curso Básico, juntamente com Moholy-Nagy, após a saída de Johannes Itten. Em 1925, passou à categoria de mestre e diretor do Curso Básico. Emigrou, em 1933 para os Estados Unidos, onde permaneceu até 1949. Nesse país desenvolveu atividade didática no Black Mountain College na Carolina do Norte, e na Universidade de Harvard, Universidade de Yale e na Cincinatti Art Academy. Desenvolveu cursos no México, Chile, Cuba, Peru, Havaí e Japão. Participou da fundação da HfG-Ulm. Ele foi particularmente importante por suas qualidades de pintor e pedagogo, reconhecidas universalmente.

71. Black Mountain College foi uma instituição de ensino superior nos Estados Unidos voltada principalmente para o ensino das artes. Sua história tem início em 1933 com o desejo do estudante John A. Rice de criar uma faculdade baseada nos princípios de educação progressista de John Dewey. A ascensão de Hitler ao poder, o fechamento da Bauhaus pelos nazistas e a perseguição de artistas e intelectuais na Europa foram acontecimentos que ajudaram na fundação da Escola, já que muitos migraram para os Estados Unidos e posteriormente foram professores ou alunos da Black Mountain College. Os fundadores acreditavam que o estudo e prática das artes eram indispensáveis para a educação, por esse motivo, seu ensino era diferente das outras universidades de época. O funcionamento também se diferenciava: todos os membros da comunidade universitária participavam de seu funcionamento, incluindo trabalho agrícola, projetos de construção e deveres na cozinha. Localizado no meio das montanhas da Carolina do Norte, perto de Asheville, o ambiente isolado promoveu um forte senso de individualidade e intensidade criativa dentro da pequena comunidade College. A faculdade foi fechada em 1957.

72. Werner Blaser (1924). Suíça. Arquiteto, designer e fotógrafo. Foi professor de design de produto em Ulm de 1955 a 1957. Trabalhou com Mies van der Rohe e Alvar Aalto. Autor de livros sobre as obras e projetos de Mies, do arquiteto japonês Tadao Ando e do espanhol Santiago Calatrava publicou também sobre a arquitetura islâmica e oriental, particularmente sobre a arquitetura japonesa, como em Tempel und Teehaus in Japan (Olten/Lausanne, Switzerland: Urs-Graf-Verlag, 1955). Seu trabalho é uma extraordinária fusão de todas essas referências.

73. Alvar Aalto (1898-1976). Finlândia. Arquiteto e designer. Graduou-se em arquitetura em 1921 na Universidade de Tecnologia de Helsinki. Foi um dos mais influentes arquitetos do movimento moderno escandinavo. Uma das características do seu trabalho é a relação com a natureza, com o uso de formas orgânicas e materiais naturais. Suas obras mais conhecidas e importantes são: Clube dos Trabalhadores em Jyväskylä [1924], Sanatório em Paimio [1929-1933], Biblioteca Municipal de Viipuri [1933-1935], Villa Mairea [1937-1939], pavilhão finlandês na Exposição Mundial de Paris [1937], o pavilhão finlandês na Feira de Nova York (1938-1939), residência estudantil do MIT em Massachusetts [1947-1949], a Universidade Politécnica de Otaniemi [1949-1967], a prefeitura de Saynatsalo [1950-1951], pavilhão finlandês na Bienal de Veneza [1956] e o Finlândia Hall em Helsinque [1967-1975]. Possui também importantes projetos no campo do mobiliário se destacando a utilização da técnica de compensado moldado com o qual ele consegue obter curvas elegantes perfeitamente adequadas às sua funções.

74. Konrad Wachsmann (1901-1980). Arquiteto alemão. Inicialmente aprendeu carpintaria e depois estudou nas academias de arte de Berlim e Dresden, de 1920 a 1924. Foi estudar com Hans Poelzig (1869-1936), em Berlim e Potsdam. Foi arquiteto chefe do maior construtor em madeira da Europa, Christoph \& Unmack AG, na baixa Silésia, em 1926. Desenvolveu um sistema de construção pré-fabricado em madeira para casas familiares, em 1925, e seu resultado mais visível foi a casa de Albert Einstein perto de Potsdam. Recebeu o prêmio Roma da Academia Prussiana de Artes, em 1932. Isso permitiria a ele desenvolver estudos por um ano na Academia Alemã em Roma na Villa Massimo. Permaneceu lá até 1938, quando foi para Paris. Wachsmann era judeu e voltar para a Alemanha nazista seria inviável. Em 1941, com a ajuda de Einstein, que já emigrara para os Estados Unidos, estabeleceu-se nesse país, onde trabalhou com Walter Gropius, desenvolvendo um sistema de painéis pré-fabricados que lhe valeu reconhecimento internacional. Ensinou no Institute of Design em Chicago e, posteriormente, na Universidade de Illinois. Mudou-se para a Universidade da Califórnia em Los Angeles, em 1964, onde trabalhou até 1974. Morreu nessa cidade em 1980, sendo enterrado, a seu pedido, em sua terra natal. 